NBER WORKING PAPER SERIES

\title{
LONG-TERM NEIGHBORHOOD EFFECTS ON LOW-INCOME FAMILIES: EVIDENCE FROM MOVING TO OPPORTUNITY
}

\author{
Jens Ludwig \\ Greg J. Duncan \\ Lisa A. Gennetian \\ Lawrence F. Katz \\ Ronald C. Kessler \\ Jeffrey R. Kling \\ Lisa Sanbonmatsu \\ Working Paper 18772 \\ http://www.nber.org/papers/w18772
NATIONAL BUREAU OF ECONOMIC RESEARCH
1050 Massachusetts Avenue
Cambridge, MA 02138
February 2013

An abridged version of this paper is forthcoming in the May 2013 American Economic Review: Papers and Proceedings. Support for this research was provided by a contract from the U.S. Department of Housing and Urban Development (HUD; C-CHI-00808) and grants from the National Science Foundation (SES-0527615), National Institute for Child Health and Human Development (R01-HD040404, R01-HD040444), Centers for Disease Control (R49-CE000906), National Institute of Mental Health (R01-MH077026), National Institute for Aging (P30-AG012810, R01-AG031259, and P01-AG005842-22S1), the National Opinion Research Center's Population Research Center (through R24-HD051152-04 from the National Institute of Child Health and Human Development), University of Chicago's Center for Health Administration Studies, U.S. Department of Education/Institute of Education Sciences (R305U070006), Bill \& Melinda Gates Foundation, John D. and Catherine T. MacArthur Foundation, Russell Sage Foundation, Smith Richardson Foundation, Spencer Foundation, Annie E. Casey Foundation, and Robert Wood Johnson Foundation. Outstanding assistance with the data preparation and analysis was provided by Joe Amick, Ryan Gillette, Ray Yun Gou, Ijun Lai, Jordan Marvakov, Nicholas Potter, Matt Sciandra, Fanghua Yang, Sabrina Yusuf, and Michael Zabek. The survey data collection effort was led by Nancy Gebler of the University of Michigan's Survey Research Center under subcontract to our research team. We thank Janet Currie and many seminar participants for helpful comments. MTO data were provided by HUD. The data used in this paper will be made available through the Inter-university Consortium on Political and Social Research (ICPSR) at the University of Michigan. The views expressed in this work are those of the authors and should not be interpreted as those of the Congressional Budget Office or HUD. The views expressed herein are those of the authors and do not necessarily reflect the views of the National Bureau of Economic Research.

At least one co-author has disclosed a financial relationship of potential relevance for this research. Further information is available online at http://www.nber.org/papers/w18772.ack

NBER working papers are circulated for discussion and comment purposes. They have not been peerreviewed or been subject to the review by the NBER Board of Directors that accompanies official NBER publications.

(C) 2013 by Jens Ludwig, Greg J. Duncan, Lisa A. Gennetian, Lawrence F. Katz, Ronald C. Kessler, Jeffrey R. Kling, and Lisa Sanbonmatsu. All rights reserved. Short sections of text, not to exceed two paragraphs, may be quoted without explicit permission provided that full credit, including (C) notice, is given to the source. 
Long-Term Neighborhood Effects on Low-Income Families: Evidence from Moving to Opportunity Jens Ludwig, Greg J. Duncan, Lisa A. Gennetian, Lawrence F. Katz, Ronald C. Kessler, Jeffrey R. Kling, and Lisa Sanbonmatsu

NBER Working Paper No. 18772

February 2013, Revised April 2013

JEL No. H43,I18,I38,J38

\section{ABSTRACT}

We examine long-term neighborhood effects on low-income families using data from the Moving to Opportunity (MTO) randomized housing-mobility experiment, which offered some public-housing families but not others the chance to move to less-disadvantaged neighborhoods. We show that 10-15 years after baseline MTO improves adult physical and mental health; has no detectable effect on economic outcomes, youth schooling and youth physical health; and mixed results by gender on other youth outcomes, with girls doing better on some measures and boys doing worse. Despite the somewhat mixed pattern of impacts on traditional behavioral outcomes, MTO moves substantially improve adult subjective well-being.

Jens Ludwig

University of Chicago

1155 East 60th Street

Chicago, IL 60637

and NBER

jludwig@uchicago.edu

Greg J. Duncan

University of California, Irvine

School of Education

2056 Education Building, Mail Code 5500

Irvine, CA 92697

gduncan@uci.edu

Lisa A. Gennetian

New York University

Institute of Human Development and

Social Change

246 Greene Street, Floor 6E

New York, NY 10003

gennetl@nber.org

Lawrence F. Katz

Department of Economics

Harvard University

Cambridge, MA 02138

and NBER

lkatz@harvard.edu
Ronald C. Kessler

Harvard Medical School

Department of Health Care Policy

180 Longwood Avenue

Boston, MA 02115

kessler@hcp.med.harvard.edu

Jeffrey R. Kling

Congressional Budget Office

3403 Ordway St NW

Washington, DC 20016

and NBER

jeffrey_kling@nber.org

Lisa Sanbonmatsu

NBER

1050 Massachusetts Avenue, 3rd Floor

Cambridge, MA 02138

lsanbonm@nber.org 
Research dating back to at least the $17^{\text {th }}$ century has shown that people living in more disadvantaged neighborhoods fare worse with respect to earnings, education, health, crime involvement and other life outcomes (Jencks and Mayer 1990; Ellen and Turner 1997; Sampson, Raudenbush, and Earls 1997; Kawachi and Berkman 2003; Sampson, Morenoff, and GannonRowley 2002; Sampson 2012). These patterns have led to concern that neighborhood environments may exert independent causal effects on people's long-term life chances. Living in a disadvantaged social environment may depress life outcomes by, for example, shaping exposure to peer norms or access to resources such as schools or job referrals. However some theories yield the opposite prediction about the effects of moving into a more affluent area, since more affluent areas could have greater discrimination and competition from advantaged peers and fewer social services for the poor.

Isolating the causal effects of neighborhood environments on behavior and well-being is complicated by the fact that most people have at least some degree of choice over where they live. Observational studies may confound neighborhood influences with those of hard-tomeasure individual- or family-level attributes that affect both residential sorting and the behavioral outcomes of interest.

Evidence on "neighborhood effects" is of growing relevance because neighborhood residential segregation by income has been increasing in the United States since 1970 even beyond the amount expected from rising income inequality alone (Reardon and Bischoff 2011). Nearly 9 million Americans live in "extreme-poverty" neighborhoods in which at least 40 percent of residents are poor (Kneebone, Nadeau, and Berube 2011). Knowledge of neighborhood effects (and the mechanisms behind such effects) is essential for evaluating 
policies that affect how people are sorted across neighborhoods and for assessing the efficiency of private housing market outcomes.

This paper examines the long-term effects on low-income parents and children of moving from very disadvantaged to less distressed neighborhoods, using data from a unique, large-scale randomized social experiment - the U.S. Department of Housing and Urban Development's (HUD's) Moving to Opportunity (MTO) demonstration. Via random lottery, MTO offered housing vouchers to families with children living in high-poverty public housing projects that facilitate moves to less-distressed areas. MTO randomization generates large, persistent differences in neighborhood conditions for otherwise comparable groups and enables us to attribute group differences in post-baseline outcomes to the offer to move through MTO.

We find that 10-15 years after randomization, MTO-assisted moves improve several key adult mental and physical health outcomes, but have no consistent detectable impacts on adult economic self-sufficiency or children's educational achievement outcomes, even for children who were too young to have enrolled in school at baseline. We also find signs of the same gender difference in the effects of MTO moves on youth risky behaviors and health found in the interim (4-7 year) follow-up, with girls doing better in some ways while boys do worse (Kling, Liebman, and Katz 2007). Despite the mixed MTO impacts on the standard outcomes that have dominated the neighborhood-effects literature, MTO moves generate a large gain in subjective well-being (SWB) for adults (Ludwig et al. 2012). 


\section{The Moving to Opportunity Experiment ${ }^{1}$}

From 1994 to 1998 MTO enrolled 4,604 low-income public housing families living in high-poverty neighborhoods within five U.S. cities: Baltimore, Boston, Chicago, Los Angeles, and New York. Families were randomized into three groups: i) the Experimental group, which received housing vouchers that subsidize private-market rents and could only be used in census tracts with 1990 poverty rates below 10 percent, and additional housing-mobility counseling; ii) the Section 8 group, which received regular housing vouchers without any MTO relocation constraint; and iii) a control group, which received no assistance through MTO. Some $48 \%$ of households assigned to the Experimental group and 63\% of those assigned to the Section 8 group moved through MTO (the MTO “compliance rate").

Data from baseline surveys show that these families were quite economically disadvantaged when they applied for MTO (see Appendix Table 1). Most household heads were African-American or Hispanic females; fewer than $40 \%$ had completed high school. Around three-quarters of applicants reported getting away from gangs and drugs as the most important reason for enrolling in MTO. As one would expect from a properly-conducted random assignment, the distribution of baseline characteristics is balanced between the treatment and control groups.

\section{Measures and Methods}

To measure long-term outcomes, our research team subcontracted with the Institute for Social Research at the University of Michigan to collect in-person data with 3,273 MTO adults and 5,105 youth who were ages 10-20 at the end of 2007. Data were collected between 2008 and

\footnotetext{
${ }^{1}$ Additional details about the Moving to Opportunity experiment and long-term follow-up data collection are reported in Sanbonmatsu et al. (2011).
} 
2010, or 10-15 years after baseline. The effective response rates equaled $90 \%$ for MTO adults and $89 \%$ for youth, and were generally similar across randomized MTO groups. Adults in the Section 8 group were interviewed slightly later than other adults because funding for this activity was secured later during the project; we discuss implications of this delay below.

To measure neighborhood conditions we collected self-report address information and passive tracking data, which we linked to census tract-level data from the 1990 and 2000 censuses and the 2005-09 American Community Surveys. We focus on duration-weighted average tract characteristics over the 10-15 year study period, since people's life outcomes may depend on cumulative exposure to neighborhood environments. Our surveys also asked MTO adults and youth to self-report about their neighborhood conditions.

Our primary focus is on indices of adult outcomes in the domains of economic outcomes, physical health, and mental health, and youth outcomes in the domains of education, physical health, mental health, and risky behavior. The outcome indices are constructed from a set of individual outcomes from our surveys that are rescaled so that higher values represent "better" outcomes and then converted to Z-scores using the control group distribution. Aggregating outcomes improves statistical power to detect impacts and reduces the risk of "false positives" by reducing the number of statistical tests carried out. To further reduce the risk of false positives due to data mining, the outcome indices we examine were pre-specified for the interim MTO follow-up done in 2002 (Kling, Liebman, and Katz 2007).

We present intention-to-treat (ITT) estimates that capture the effect of being offered the chance to use an MTO voucher to move into a different neighborhood. These estimates are calculated as the difference in average outcomes for families assigned to treatment versus the control condition, by regressing an outcome index against indicators for treatment-group 
assignment and (pre-random assignment) baseline covariates that include indicators for MTO demonstration site and participant socio-demographic characteristics to improve precision (see Appendix Table 1). The estimates are weighted to account for changes over time in the probability of treatment assignment due to higher-than-expected compliance rates.

We also present estimates of the effects of treatment on the treated (TOT), which use random assignment indicators as instruments for moving through MTO in the Experimental or Section 8 groups and assume the treatment assignment only affects families who move using a MTO voucher (Bloom 1984; Angrist, Imbens, and Rubin 1996). The TOT estimates are about twice as large as the estimated ITT effects for the Experimental group and about 1.6 times as large as the ITT effect for the Section 8 group.

\section{Results}

One year after baseline, the average control group adult was living in a neighborhood with an average tract poverty rate of 50 percent (Appendix Table 2). Moving with an Experimental voucher reduced average tract poverty rates one year after baseline by 35 percentage points (2.85 standard deviations in the 2000 census tract poverty distribution), while moving through MTO with a regular Section 8 voucher reduced tract poverty rates by 21 percentage points (1.73 standard deviations). These differences across MTO groups in neighborhood conditions narrowed over time, mostly because the average neighborhood poverty rates for the control group declined.

Despite the partial convergence of neighborhood conditions across MTO groups over the study period, MTO-induced differences in duration-weighted average tract poverty rates over the course of the 10-15 year follow-up period were quite sizable. Figure 1 shows that a large share of 
adults who moved with an Experimental-group voucher (the Experimental Group Compliers) had an average tract poverty rate below $20 \%$, which was true for few control group families. The effects of moving with a regular Section 8 voucher on average tract poverty rates were somewhat less pronounced. (Appendix Table 2 presents MTO impacts on a broader set of neighborhood characteristics.)

Contrary to the widespread view that living in a disadvantaged inner-city neighborhood depresses labor market outcomes, Table 1 shows that being offered a voucher through MTO did not improve economic self-sufficiency, at least for this study sample. Although the ITT estimate for the Section 8 group was negative and marginally significant $(\mathrm{p}<.10)$, we believe this was most likely an artifact of our interviewing the Section 8 group adults a bit later than control adults, when labor market conditions were less favorable (see Sanbonmatsu et al. 2011).

The results in Table 1 also hint at some potentially positive impacts of MTO on adult mental and physical health outcomes, with ITT effects on these broad health outcome indices that were in the direction of better health but not quite statistically significant. However some specific individual health outcomes showed large and statistically significant improvements in response to MTO-assisted moves. For example, moving with an Experimental-group voucher (the TOT effect) reduced the prevalence of having a body mass index of 40 or more (BMI, defined as weight in kilograms divided by the square of height in meters) by 7 percentage points. This was a decline of nearly $40 \%$ of the control group mean of 18 percent (Ludwig et al. 2011). For a five-foot-four woman, a BMI of 40 would correspond to a weight of about 235 pounds. We also found the Experimental-voucher TOT effect reduced the prevalence of diabetes, measured from blood samples and defined as having a level of glycosylated hemoglobin (HbA1c) $\geq 6.5 \%$, by 10 percentage points, or one-half of the control group's rate. 
We found no evidence that MTO had beneficial impacts on youth educational outcomes. Effects on math and reading test scores were very close to zero both for youth who were preschool age at baseline and for youth who were ages 6 and up at baseline. MTO did tend to have some beneficial effects on female but not male youth in other outcome domains (Table 2). Assignment to the Experimental and Section 8 groups improved physical health for girls, while the Experimental-group effect on mental health outcomes is also positive and statistically significant for girls. The estimated effects on health outcomes for boys ranged from zero to negative (worse health). We can reject the null hypothesis that the physical and mental health impacts of the Experimental treatment were the same by gender (Appendix Table 3).

\section{Extensions}

The MTO findings about the effects of changes in neighborhood environments on key outcomes like economic self-sufficiency and children's schooling outcomes run counter to much of what previous theories and observational research have suggested. One common explanation for this discrepancy is that MTO generates too small of a "treatment dose" on neighborhood environments to provide a meaningful test of "neighborhood effects" theories. This section discusses that issue and also provides some additional results showing MTO's effects on various behavioral outcomes. 


\section{A. Impacts on neighborhood environments}

In this section we provide more details on the nature and magnitude of MTO's effects on the neighborhood conditions in which families were living during our study period.

\section{A1. MTO effects on neighborhood poverty}

Appendix Table 2 shows that one year after random assignment, the average control group family was living in a neighborhood that had a poverty rate of 50 percent or 2.92 standard deviations (SD) above the national average in the 2000 census nationwide tract-poverty distribution. The ITT effect on neighborhood poverty was 17 percentage points for the Experimental group and 13 percentage points for the Section 8 group at one year after random assignment. Actually moving with an Experimental-group voucher reduced average tract poverty rates by 35 percentage points, or $2.85 \mathrm{SD}$ - moving families almost down to the national average poverty rate. The effect of moving with a regular Section 8 voucher that did not have the mobility restriction was smaller but still sizable - equal to 21 percentage points or $1.73 \mathrm{SD}$ in the national distribution.

Over time the MTO effect on neighborhood conditions declined, due partly to secondary moves by MTO families after their initial MTO-assisted voucher moves but mostly to declines over time in the average tract poverty rate of families in the control group. For example, the Experimental-voucher TOT effect on tract poverty rates was 35 percentage points measured 1 year after baseline and about 8 percentage points measured 10-15 years after baseline, a decline of 27 percentage points. Much of this attenuation of the MTO effect on neighborhood poverty rates came from the fact that the average tract poverty rate for control families declined from 50 percent one year after baseline down to 31 percent 10-15 years after baseline, a drop of 19 percentage points. Most of the decline in neighborhood poverty rates among families in the 
control group was due to mobility rather than to gentrification of the neighborhoods in which control families were living. This conclusion came from results (not shown) that re-estimated MTO impacts on neighborhood conditions at different points in time since randomization but holding the poverty rates of all tracts constant at their levels in the 2000 census.

Whatever the cause, it is clear that the neighborhood conditions of the MTO treatment and control groups partially converged over time. Because behavioral change may require accumulated exposure to neighborhood environments, however, we also examined the average neighborhood conditions that families experienced over the entire post-randomization period. Appendix Table 2 shows that over the course of the study period the average control group family lived in a census tract with a poverty rate of 40 percent. Moving with an Experimental voucher reduces average tract poverty rates for families by 18 percentage points. This decline is quite large, amounting to nearly one-half the control mean and 1.48 standard deviations in the 2000 national tract poverty distribution, and much larger than poverty reductions that might be accomplished with almost any place-based neighborhood policy.

Another way to consider the size of the MTO "treatment dose" on neighborhood conditions is to ask how much larger such a dose could possibly be from a large-scale mobility program. The answer is not much. A common measure of residential segregation is the "dissimilarity index," defined as the share of people who would need to be moved across census tracts within a given area in order to have the share of poor people in each tract equal the share of the larger area that is poor. The five MTO demonstration cities have poverty rates right now around 20 percent. $^{2}$ The average tract poverty rate of MTO Experimental group movers (about 21 percent) roughly corresponds to the dissimilarity-index benchmark of perfect poverty

\footnotetext{
${ }^{2}$ Data from the Census Bureau's American Community Survey for 2006 through 2010 show the poverty rates for the five MTO cities are: Baltimore (21.3 percent); Boston (21.2); Chicago (20.9); Los Angeles (19.5); and New York (19.1). See www.census.gov.
} 
integration in these MTO cities. The national poverty rate in the U.S. as a whole right now is 15 percent, so even if a residential mobility program were to move inner-city families at random across neighborhoods all over the country, there is scope for achieving more economic integration than was achieved in the MTO Experimental group when the overall poverty rate is 15 or 20 percent.

\section{A2. MTO effects on other neighborhood conditions}

Although MTO focused explicitly on reducing economic rather than racial segregation for participating families, one might have expected important changes in neighborhood racial segregation as a byproduct of the MTO moves, given that residents of high-poverty neighborhoods are very disproportionately likely to be Hispanic or African-American (Jargowsky 1997; Jargowsky 2003). Appendix Table 2 makes clear, however, that MTO’s impacts on racial segregation for participants were fairly modest and much smaller than impacts on economic segregation. The average control group family spent the study period living in a census tract that was 88 percent minority. The tract share minority for those who moved with an Experimental voucher was lower by a statistically significant amount, but the TOT effect of about 12 percentage points means that, over the study period, even the Experimental-group movers were living in census tracts in which fully three-quarters of all residents were members of racial and ethnic minority groups.

Despite the lack of MTO impact on neighborhood racial composition, MTO moves led to sizable changes in neighborhood social processes that a growing body of sociological research suggests might be particularly important in affecting people's life outcomes (see for example Sampson, Morenoff, and Gannon-Rowley 2002; Sampson 2012). For example Appendix Table 2 shows that in survey self-reports 10 to 15 years after baseline - after the partial convergence in 
neighborhood poverty rates between treatment and control groups had occurred - the Experimental-voucher TOT effect on the chance of having at least one college-educated friend was nearly 15 percentage points, or about a third of the control mean of 53 percent. The Experimental-voucher TOT effect on the likelihood that neighbors would do something if local youth were spraying graffiti (intended to measure what Sampson, Raudenbush, and Earls (1997), call "collective efficacy" - the willingness of neighbors to work together to enforce shared social norms) was over 16 percentage points, more than a quarter of the control mean of 59 percent. MTO also changed safety - the neighborhood condition that was the main reason most MTO families originally signed up for the program. Moving with an Experimental voucher reduced the local violent-crime rate (as measured by police data) by 833 violent crimes per 100,000 residents, over one-third of the control mean of $2,317 .{ }^{3}$ Self-reported data about neighborhood safety showed similarly large effects. The Experimental-voucher TOT effect on the likelihood that adults reported feeling unsafe in their neighborhood during the day equaled 8 percentage points, over one-third of the control group's rate of 20 percent. The likelihood of having seen drugs used or sold in the neighborhood over the past month was 13 percentage points lower in the Experimental group than the control group value of 31 percent.

Because moving itself is part of the MTO treatment and could have independent effects on people's life outcomes, it is important to keep in mind that the control group averaged about 2.2 moves over the course of the 10-15 year follow-up study period. Treatment assignment increased the average number of moves over 10 to 15 years by about half a move.

\footnotetext{
${ }^{3}$ The results reported here for local-area crime rates are slightly different from those reported in Ludwig (2012) due to corrections and updates to the available administrative crime records used for analysis.
} 


\section{B. Additional Impacts on Behavioral Outcomes}

The results presented in Table 1 above provide a broad summary of the effects of MTOassisted moves on the behavioral outcomes of adults, while the results in Table 2 summarize the effects on youth. In this section we provide more details about impacts on the individual outcomes that underlie these broad outcome indices.

\section{B1. MTO impacts on adult outcomes}

Given the widely held view that living in a disadvantaged neighborhood depresses earnings and employment, due to peer norms or lack of access to informal job referrals or some other reason, one of the most surprising findings shown in Table 1 is that moving to a lessdistressed area with a regular Section 8 voucher seems to have reduced economic selfsufficiency. As noted above, we believe that this is most likely a spurious result - a consequence of having secured funding to survey the Section 8 adults later in the research project and therefore interviewing them later in calendar time, when labor market conditions were weaker as a result of the economic recession, than when we interviewed the control group.

The top of Appendix Table 4 shows that MTO impacts on survey reports of adult economic outcomes are not statistically significant for the Experimental group, but for the Section 8 group tend to be in the direction of worse economic outcomes. However the bottom panel of Appendix Table 4 shows MTO impacts on adult employment rates and earnings as measured by quarterly administrative records obtained from state unemployment insurance (UI) systems, which we can use to measure outcomes at a common point in time across groups. We found no signs of a negative effect on economic outcomes in the Section 8 group with administrative data. We can also see this in Appendix Figure 2, which shows quarter-by-quarter employment rates for all three randomized MTO groups. Experimental group employment rates 
increased dramatically in the early years of the program, which coincided with welfare reform and very low unemployment, but the control group employment rates tracked these employment rate changes very closely during these as well as later years of the study period.

Although Table 1 shows that the overall MTO impacts on our broad physical and mental health outcome indices were not quite statistically significant, MTO did significantly improve several important individual indicators of health as described in Appendix Table 5. For example, the top panel shows that moving with an MTO Experimental group voucher reduced an indicator of short-term psychological distress (the K6 index) by one-fifth of a standard deviation, with impacts of moving with a regular Section 8 voucher roughly half as large.

MTO had no detectable effects on overall self-reported health status, but we found sizable impacts on a variety of specific health conditions. Moving with an Experimental voucher reduced the chances that MTO adults had difficulty lifting groceries by about 10 percentage points or one-fifth the control mean. Appendix Table 5 also shows MTO impacts on diabetes and measures of obesity and extreme obesity- based on different cut-points in the BMI distribution taken from Ludwig et al. (2011). Although the interim MTO study found that MTO reduced obesity prevalence, defined as $\mathrm{BMI} \geq 30$, we found no impact on this outcome in the long-term data - perhaps because nearly three in five MTO adults are obese in those data. We did find sizable impacts at higher BMI cut points. Moving with either an Experimental or regular Section 8 voucher reduced the likelihood of having $\mathrm{BMI} \geq 35$ by about 9 or 10 percentage points, over a quarter of the control mean of 35 percent. The Experimental-voucher TOT effect on extreme obesity (BMI $\geq 40$ ) was 7 percentage points, 40 percent of the control mean of 18 percent. We used blood samples to measure diabetes, since nearly a third of all diabetes cases are undiagnosed (Cowie et al. 2006) and the likelihood of diagnosis could vary across areas. The 
Experimental-voucher TOT effect on diabetes was a reduction of 10 percentage points, about half the control-group mean of 20 percent.

Because economic outcomes and particularly health outcomes are expected to vary by age, it is possible that MTO's effects on adult outcomes could also have varied by age. Appendix Table 6 presents results for economic outcomes and individual health outcomes separately for adults who were under 33 years of age versus 33 years and older at the time of random assignment. We found little consistent evidence that there were detectable differences in longrun MTO impacts on adults by age.

Although MTO has overall a mixed pattern of impacts on the sort of traditional measure of objective outcomes that dominate the neighborhood-effects literature, Appendix Table 7 (reproduced from the supplemental appendix to Ludwig et al. (2012)) shows that MTO moves nonetheless generated very sizable gains in adult self-reports of subjective well-being (SWB). The long-term MTO data included the standard SWB measure that has been used as part of the General Social Survey ("Taken all together, how would you say things are these days - would you say that you are very happy, pretty happy, or not too happy?") The proper interpretation of SWB measures remains the topic of some debate. Previous studies have shown different measures of self-reported SWB to be correlated in expected ways with objective indicators of well-being such as life events, biological indicators, and reports by other people about the person's happiness (see for example Kahneman and Krueger (2006) and Oswald and Wu (2010)). The TOT effects on SWB equaled 0.16SD for the Experimental group and 0.19SD for the Section 8 group.

Appendix Figure 3 (taken from Ludwig et al. (2012)) suggests that adult SWB was more strongly affected by neighborhood economic segregation than by racial segregation. The analysis 
estimates the relationship between SWB and duration-weighted neighborhood characteristics measures by using interactions of MTO treatment assignment and city indicators as instrumental variables to deal with the endogeneity of neighborhood location. Panel A shows that there was a negative relationship between SWB and average tract poverty rates when that is the only neighborhood measure included as an explanatory variable in the model. Panel B shows the same was true for the relationship between SWB and tract minority share. When tract poverty and tract minority share are included in the model at the same time, SWB had an even more pronounced negative relationship with tract poverty (Panel C) but SWB had a positive relationship with tract minority share (Panel D). A qualitatively similar pattern held for our broad indices for outcomes in the physical and mental health domains as well (see Appendix Tables 8 and 9 for details).

This pattern is important because while racial segregation has been declining in the U.S. since 1970, to levels not seen since 1970 (Glaeser and Vigdor 2012), income segregation has been increasing since 1970 (Watson 2009; Reardon and Bischoff 2011). Our results suggest the adverse effect of disadvantaged neighborhood environments on the well-being of poor families has been getting worse over time, and that trends over time in growing inequality in family income may understate the growth over time in the inequality of overall well-being.

\section{B2. MTO impacts on youth outcomes}

Appendix Table 10 shows that the long-term data are qualitatively consistent with the interim MTO study in showing a gender difference in MTO impacts on youth - with female youth having had positive impacts on some outcomes, while males had negative impacts although the youth impacts were generally more muted in the long-term than interim data. ${ }^{4}$ For

\footnotetext{
${ }^{4}$ These youth estimates for MTO ITT and TOT effects come from a set of regressions that have a similar specification to those for the MTO adult sample, but now cluster standard errors at the baseline-household level to account for the non-independence of observations for children drawn from the same family, and control for a slightly different set of baseline covariates (see Appendix Table 1B).
} 
female youth MTO moves with either an Experimental or regular Section 8 voucher reduced the share overweight (which for youth is defined as BMI $\geq 95^{\text {th }}$ percentile), with an ITT effect equal to about five percentage points or a fifth of the control mean. ${ }^{5}$ The Experimental-voucher moves also improved mental health, as indicated by declines in the K6 measure of short-term psychological distress. For male youth most of the impacts were either not statistically significant or tended to indicate worse outcomes as a result of MTO moves, for example with respect to injury prevalence, smoking, or likelihood of being educationally on track. We found no signs of the large declines in youth violence rates found among both male and female youth in the interim MTO data (Kling, Ludwig, and Katz 2005).

We note that the set of youth we surveyed for the long-term MTO study, ages 10-20 at the end of 2007, overlaps very little with youth analyzed in the interim MTO study, who were 10-20 at the end of 2001. Our long-term results thus help confirm the previous (surprising) results for the gender difference in MTO impacts among a different group of MTO children. We found few statistically significant MTO impacts on educational outcomes in the longterm data, either with respect to measures of school persistence or achievement test scores (Panel C of Appendix Table 10). ${ }^{6}$ The standard errors around our estimates indicate that impacts on achievement test scores larger than about 0.10 or 0.15 SD were very unlikely.

\footnotetext{
${ }^{5}$ Our main results define childhood obesity using the Centers for Disease Control definition - body mass index above the $95^{\text {th }}$ percentile for a given age-sex group as estimated from a set of national health studies collected in the 1960s through 1990s (www.cdc.gov/nchs/data/ad/ad314.pdf). This result (and hence the results for the overall physical health index for female youth) is somewhat sensitive to using alternative definitions of childhood obesity; for example the result is not quite statistically significant when we instead use the definition developed by the International Obesity Task Force, which uses a different set of age-sex BMI cut points derived from international data; for additional details see Sanbonmatsu et al. (2011).

${ }^{6}$ Our in-person interviews with MTO youth included a 45-minute achievement assessment in math and reading as designed for the $5^{\text {th }}$ and $8^{\text {th }}$ grade follow-up waves of the U.S. Department of Education's Early Childhood Longitudinal Study- Kindergarten Cohort (ECLS-K). Youth ages 10-12 were administered the $5^{\text {th }}$ grade test, while youth ages 13-20 at the end of 2007 were administered the $8^{\text {th }}$ grade test. To guard against the possibility that some 13-20 year olds would find the items on the $8^{\text {th }}$ grade test too easy and answer every item correctly, in which case the assessment would lose its ability to provide information about which youth in the study know more than others (a "ceiling effect"), we supplemented the ECLS-K $8^{\text {th }}$ grade test with a small set of math and reading items from the
} 
One of the main motivations for following up with youth in the long-term study was the possibility that youth who were very young at baseline may have experienced particularly pronounced gains from MTO moves. After all, children who were pre-school age at baseline did not yet really have social networks or a sense of social identity before they moved. Moreover they experienced massive changes in neighborhood poverty (up to 3SD in the national distribution one year after randomization) during the life stage when children are thought to be most developmentally malleable. Yet Appendix Table 11 shows that even for children who were under age 6 at baseline we found no signs of any detectable changes in achievement test scores.

The MTO effects that we do observe among youth - health impacts on female youth seem to be driven more by neighborhood economic disadvantage than neighborhood minority composition. Appendix Tables 12 and 13 present the results of using interactions of indicators for MTO treatment-group assignment and baseline demonstration site as instruments for duration-weighted tract poverty or tract minority share, and show little evidence of a 'doseresponse' relationship between either measure and any outcomes when we look at all youth together. The same is true when we look at male youth (Appendix Tables 16 and 17). However Appendix Table 14 shows that the MTO effect on physical health of female youth is more strongly related to tract poverty than tract minority share when each is included one at a time as the endogenous explanatory variable in our instrumental variables model. When both are included in the same IV model simultaneously, we can reject the null hypothesis that the coefficients on tract poverty and tract minority share are the same (Appendix Table 15). The data provide some suggestive indication that mental health for female youth might also be more strongly related to tract poverty than tract minority share; when both are included in the same IV our table here report just on youth who were 13-20 at the end of 2007 who took the $8^{\text {th }}$ grade test; results are similar for the 10-12 year olds. 
model at the same time the coefficient is much larger in absolute value for tract poverty, although given the standard errors around our estimates we cannot reject the null hypothesis that the coefficients on tract poverty and minority share are the same.

\section{Discussion}

The MTO long-term results did not provide support for the view that high rates of school failure and non-employment in central city neighborhoods are due to the direct adverse effects of living in a poor neighborhood. The pattern of findings was consistent with the results from the 47 year interim follow-up of MTO adults and youth (Kling, Liebman, and Katz 2007). Our long-

term data also showed no detectable impacts on academic achievement for children of pre-school age at baseline even though MTO led to very large changes in their neighborhood conditions at a life stage when they may be most developmentally malleable.

One obvious question involves generalizability: Do neighborhood changes have no impact on earnings or educational achievement outcomes here because the MTO study sample is somehow unusual? MTO families were drawn from extremely distressed communities. The baseline census tracts for MTO families were fully 3 standard deviations above the national average in the 2000 census tract-poverty distribution. On the other hand much of the scientific and policy concern about "neighborhood effects" is precisely with families living in the most distressed areas. And previous observational studies report finding impacts on samples similar to the MTO sample.

Looking at broad indices of outcomes that were pre-specified for the interim MTO data, we found suggestive (but not always statistically significant) signs that physical and mental health outcomes improved for adult women and female youth. We found very large MTO 
impacts on specific health measures, particularly those related to extreme obesity and diabetes. Although we acknowledge that measuring candidate mechanisms like diet, exercise and access to health care is intrinsically challenging, and that our available data on these factors are quite limited, it is noteworthy that MTO moves reduced extreme obesity and diabetes by fully $40-50 \%$ for adults while generating almost no detectable changes in our measures of these candidate mediators. One hypothesis for why MTO improved physical health is because of MTO's beneficial impacts on neighborhood safety, and subsequent gains in mental health - including psychological distress. This safety-stress-health hypothesis is also consistent with our finding that the majority of MTO households signed up to move to new neighborhoods through MTO because of concerns about crime and violence.

The long-term MTO data did not show any signs of the large drop in violent-crime arrests that were found in the 4-7 year MTO follow-up among both male and female youth (Kling, Ludwig, and Katz 2005). However the long-term data did echo the interim data to some extent in showing female youth may benefit from MTO moves in other outcome domains like mental health or risky behaviors, but male youth tended to do no better (or do worse) as a result of such moves. The reason for these gender differences remains unclear; they do not seem to be due merely to gender differences in the prevalence of these outcomes or behaviors.

The magnitudes of these gender differences in MTO impacts were smaller in the longterm than interim data, just as the difference across MTO groups in neighborhood conditions was smaller at the time of the long-term surveys than interim surveys. These patterns suggest youth outcomes may be more affected by contemporaneous neighborhood conditions than accumulated exposure to neighborhood environments, or what Sampson (2012) calls "situational" neighborhood effects as opposed to "developmental" neighborhood effects. 
The MTO data make clear that neighborhood environments have important impacts on the overall quality of life and well-being of low-income families despite the mixed pattern of impacts on traditional "objective" outcome measures, including null effects on earnings and education. Ludwig et al. (2012) showed that a 1 standard deviation decline in census tract poverty rates (about 13 percentage points) was associated with an increase in SWB that is about the same size as the difference in SWB between households whose annual incomes differ by $\$ 13,000$ - a very large amount given that the average control group family's annual income in the long-term survey was just $\$ 20,000$. 


\section{REFERENCES}

Angrist, Joshua D., Guido W. Imbens, and Donald B. Rubin. 1996. "Identification of Causal Effects Using Instrumental Variables." Journal of the American Statistical Association 91 (434): 444-455.

Bloom, Howard S. 1984. "Accounting for No-Shows in Experimental Evaluation Designs." Evaluation Review 8 (2): 225-246.

Cowie, Catherine C., Keith F. Rust, Danita D. Byrd-Holt, Mark S. Eberhardt, Katherine M. Flegal, Michael M. Engelgau, Sharon H. Saydah, Desmond E. Williams, Linda S. Geiss, and Edward W. Gregg. 2006. "Prevalence of Diabetes and Impaired Fasting Glucose in Adults in the U.S. Population.” Diabetes Care 29 (6): 1263-1268. http://care.diabetesjournals.org/content/29/6/1263.abstract.

Ellen, Ingrid G., and Margery A. Turner. 1997. "Does Neighborhood Matter?” Housing Policy Debate 8 (4): 833-66.

Glaeser, Edward L., and Jacob L. Vigdor. 2012. The End of the Segregated Century: Racial Separation in America's Neighborhoods, 1980-2010. New York. www.manhattaninstitute.org/pdf/cr_66.pdf.

Jargowsky, Paul A. 1997. Poverty and Place: Ghettos, Barrios and the American City. New York: Russell Sage Foundation.

- 2003. Stunning Progress, Hidden Problems: The Dramatic Decline of Concentrated Poverty in the 1990s. Washington, DC.

Jencks, Christopher, and Susan E. Mayer. 1990. "The Social Consequences of Growing up in a Poor Neighborhood." In Inner-City Poverty in the United States, ed. Laurence Lynn and Michael McGeary, 111-186. Washington, DC: National Academy Press.

Kahneman, Daniel, and Alan B. Krueger. 2006. "Developments in the Measurement of Subjective Well-Being.” Journal of Economic Perspectives 20 (1): 3-24.

Kawachi, Ichiro, and Lisa F. Berkman, eds. 2003. Neighborhoods and Health. New York: Oxford University Press.

Kling, Jeffrey R., Jeffrey B. Liebman, and Lawrence F. Katz. 2007. "Experimental Analysis of Neighborhood Effects." Econometrica 75 (1): 83-119.

Kling, Jeffrey R., Jens Ludwig, and Lawrence F. Katz. 2005. "Neighborhood Effects on Crime for Female and Male Youth: Evidence from a Randomized Housing Voucher Experiment." Quarterly Journal of Economics 120 (1): 87-130. 
Kneebone, Elizabeth, Carey Nadeau, and Alan Berube. 2011. "The Re-Emergence of

Concentrated Poverty: Metropolitan Trends in the 2000s". Washington, DC: The Brookings Institution, Metropolitan Policy Program.

www.brookings.edu/ /media/Files/rc/papers/2011/1103_poverty_kneebone_nadeau_berube /1103_poverty_kneebone_nadeau_berube.pdf.

Ludwig, Jens. 2012. "The Long-Term Results From the Moving to Opportunity Residential Mobility Demonstration." Cityscape 14 (2): 1-28.

Ludwig, Jens, Greg J. Duncan, Lisa A. Gennetian, Lawrence F. Katz, Ronald C. Kessler, Jeffrey R. Kling, and Lisa Sanbonmatsu. 2012. "Neighborhood Effects on the Long-Term WellBeing of Low-Income Adults.” Science 337 (6101): 1505-1510.

Ludwig, Jens, Lisa Sanbonmatsu, Lisa Gennetian, Emma Adam, Greg J. Duncan, Lawrence F. Katz, Ronald C. Kessler, et al. 2011. "Neighborhoods, Obesity, and Diabetes-a Randomized Social Experiment.” The New England Journal of Medicine 365 (16): 1509-19.

Oswald, Andrew J., and Stephen Wu. 2010. "Objective Confirmation of Subjective Measures of Human Well-being: Evidence from the U.S.A.” Science 327 (5965): 576-579.

Reardon, Sean F., and Kendra Bischoff. 2011. "Income Inequality and Income Segregation." American Journal of Sociology 116 (4): 1092-1153.

Sampson, Robert J. 2012. Great American City: Chicago and the Enduring Neighborhood Effect. Chicago: University of Chicago Press.

Sampson, Robert J., Jeffrey D. Morenoff, and Thomas Gannon-Rowley. 2002. "Assessing 'Neighborhood Effects': Social Processes and New Directions in Research.” Annual Review of Sociology 28 (1): 443-478.

Sampson, Robert J., Stephen W. Raudenbush, and Felton Earls. 1997. "Neighborhoods and Violent Crime: a Multilevel Study of Collective Efficacy.” Science 277 (5328): 918-924.

Sanbonmatsu, Lisa, Jens Ludwig, Lawrence F. Katz, Lisa A. Gennetian, Greg J. Duncan, Ronald C. Kessler, Emma Adam, Thomas W. McDade, and Stacy Tessler Lindau. 2011. Moving to Opportunity for Fair Housing Demonstration Program: Final Impacts Evaluation. Washington, DC: U.S. Department of Housing and Urban Development, Office of Policy Development and Research. www.huduser.org/publications/pdf/MTOFHD_fullreport_v2.pdf.

Watson, Tara. 2009. "Inequality and the Measurement of Residential Segregation By Income in American Neighborhoods." Review of Income and Wealth 55 (3): 820-844. 


\section{Exhibit List}

Main Exhibits

Figure 1. Densities of Average Poverty Rate by Treatment Group

Table 1. Intent-to-Treat Effects on MTO Adults

Table 2. Intent-to-Treat Effects on MTO Youth

\section{Appendix Figures}

1. Densities of Average Poverty Rate by Treatment Group

2. Employment Rates Over Time by Treatment Group

3. Instrumental Variable Estimation of the Relationship between Subjective Well-Being and Tract Poverty Rate and Tract Share Minority

\section{Appendix Tables}

1. Baseline Characteristics (1994-98) Controlled for in the Main Analysis

1B. Additional Baseline Characteristics Controlled for in the Youth Analysis

2. Effects on Expanded Set of Housing and Neighborhood Condition Measures

3. Intent-to-Treat Effects on Summary Measures of Outcomes

4. Effects on Adult Economic Self-Sufficiency

5. Effects on Adult Mental and Physical Health

6. Intent-to-Treat Effects on Adult Economic Self-Sufficiency and Health by Age at Baseline

7. Effects on Adult Subjective Well-Being

8. Instrumental Variables Estimates of the Relationship between Adult Outcomes and DurationWeighted Tract Poverty Rate or Tract Share Minority

9. Instrumental Variables Estimates of the Relationship between Adult Outcomes and DurationWeighted Tract Poverty Rate and Tract Share Minority in One Model

10. Intent-to-Treat Effects on Youth Outcomes

11. Intent-to-Treat Effects on Youth Achievement Assessment Scores, by Gender and Age at Baseline

12. Instrumental Variables Estimates of the Relationship between Youth Outcomes and DurationWeighted Tract Poverty Rate or Tract Share Minority

13. Instrumental Variables Estimates of the Relationship between Youth Outcomes and DurationWeighted Tract Poverty Rate and Tract Share Minority in One Model

14. Instrumental Variables Estimates of the Relationship between Female Youth Outcomes and Duration-Weighted Tract Poverty Rate or Tract Share Minority

15. Instrumental Variables Estimates of the Relationship between Female Youth Outcomes and Duration-Weighted Tract Poverty Rate and Tract Share Minority in One Model

16. Instrumental Variables Estimates of the Relationship between Male Youth Outcomes and DurationWeighted Tract Poverty Rate or Tract Share Minority

17. Instrumental Variables Estimates of the Relationship between Male Youth Outcomes and DurationWeighted Tract Poverty Rate and Tract Share Minority in One Model 


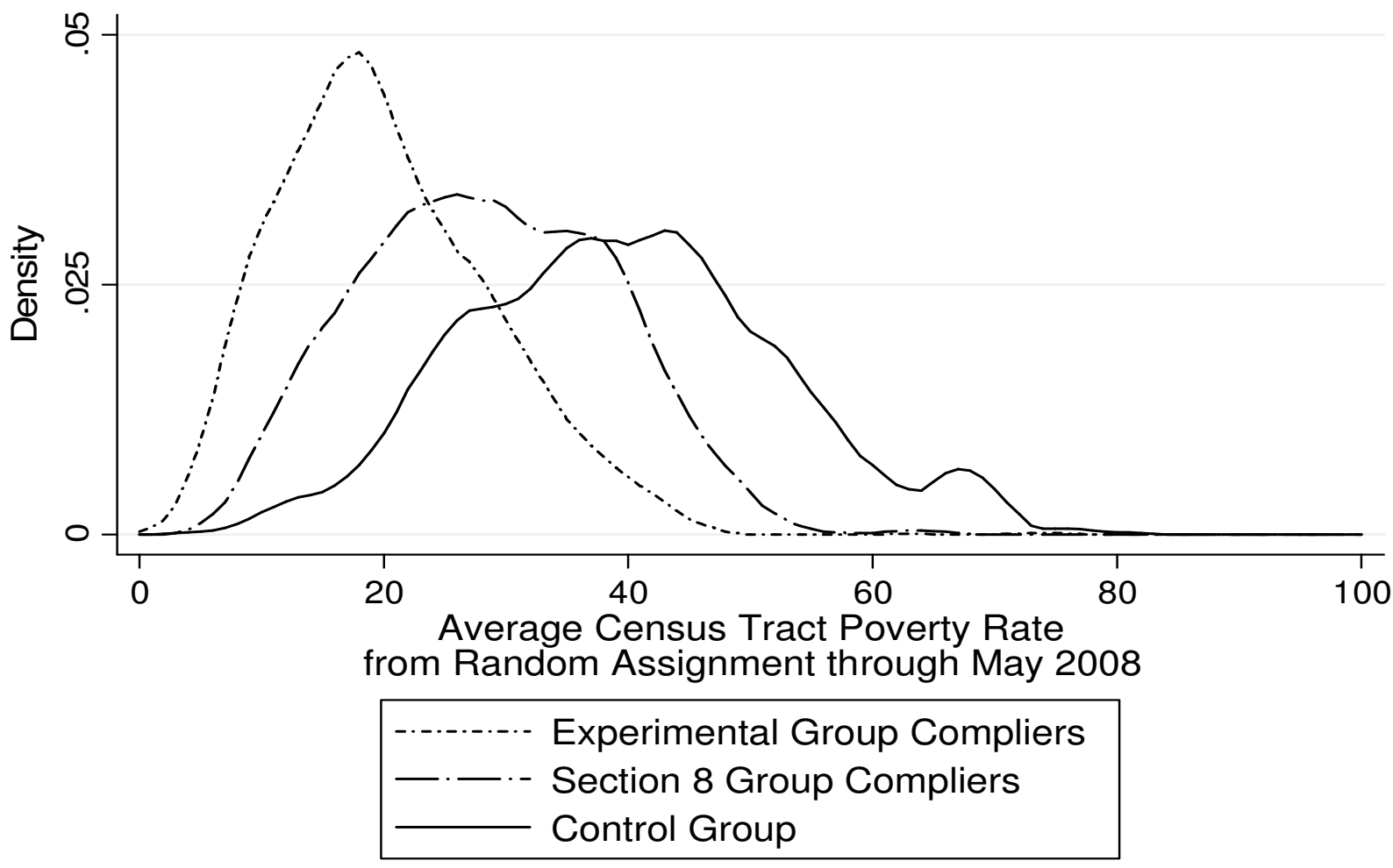

\section{FIGURE 1. DENSITIES OF AVERAGE POVERTY RATE BY TREATMENT GROUP}

Notes : Duration-weighted average of census tract poverty at all addresses from random assignment through May 2008 (just prior to the long-term survey period), based on linear interpolation of 1990 and 2000 decennial census and the 200509 American Community Survey data. Density estimates used an Epanechnikov kernel with a half-width of 2.

Source and Sample: The sample is all adults who were interviewed as part of the long-term survey (with Experimental and Section 8 group adults limited to those who used an MTO voucher to move). Sample sizes in the Experimental, Section 8 , and control groups are 711,413, and 1,139. 
TABLE 1 - MTO IMPACTS ON ADULT OUTCOMES

\begin{tabular}{lccc}
\hline \hline & Experimental vs. Control & & Section 8 vs. Control \\
\cline { 2 - 2 } Panel A. Outcome indices (z-scores) & & \\
Index for all outcomes & 0.037 & -0.010 \\
& $(0.040)$ & $(0.059)$ \\
Economic self-sufficiency & -0.029 & $-0.112 *$ \\
& $(0.040)$ & $(0.059)$ \\
Absence of physical health problems & 0.055 & 0.062 \\
& $(0.042)$ & $(0.058)$ \\
Absence of mental health problems & 0.069 & 0.063 \\
Panel B. Selected individual health outcomes & $(0.042)$ & $(0.062)$ \\
Psychological distress, K6 z-score & & -0.081 \\
& $-0.106 * *$ & $(0.060)$ \\
BMI $\geq 40$ & $(0.042)$ & $-0.038 *$ \\
Blood test detected diabetes (HbA1c $\geq 6.5 \%)$ & $-0.036 * *$ & $(0.023)$ \\
& $(0.016)$ & -0.015 \\
& $-0.050 * * *$ & $(0.026)$ \\
\hline
\end{tabular}

Notes: Estimates are the intent-to-treat effect sizes from an ordinary least squares regression of each outcome on treatment indicators and the baseline covariates listed in Appendix Table 1. Robust standard errors are in parentheses. Outcome indices and psychological distress are z-scores using the mean and standard deviation for the control group. Index components are (positive outcomes (+) included as is, while signs for negative outcomes (-) were reversed so that higher values indicate "better" outcomes): Economic: + adult employed and not on TANF + employed + earnings - on TANF - government income. Mental health: - distress - depression - Generalized Anxiety + calmness + sleep. Physical health: - self-reported health fair/poor - asthma attack past year - obesity hypertension - trouble carrying/climbing. The index for all outcomes includes the 15 measures from the three indices. Psychological distress consists of 6 items (e.g. sadness) scaled on a score from 0 to 24 (highest distress). Source and Sample: The sample is all adults who were interviewed as part of the long-term survey. Sample sizes in the Experimental, Section 8, and Control groups are 1,456, 678, and 1,139.

*** Significant at the 1 percent level.

** Significant at the 5 percent level.

* Significant at the 10 percent level. 
TABLE 2 - MTO IMPACTS ON YOUTH OUTCOMES

\begin{tabular}{|c|c|c|c|c|}
\hline & $\begin{array}{c}\text { Experimental } \\
\text { vs. Control }\end{array}$ & $\begin{array}{c}\text { Section } 8 \\
\text { vs. Control } \\
\end{array}$ & $\begin{array}{c}\text { Experimental } \\
\text { vs. Control }\end{array}$ & $\begin{array}{c}\text { Section } 8 \\
\text { vs. Control } \\
\end{array}$ \\
\hline \multicolumn{5}{|l|}{ Panel A. Outcome indices (z-scores) } \\
\hline & \multicolumn{2}{|c|}{ Female Youth } & \multicolumn{2}{|c|}{ Male Youth } \\
\hline \multirow[t]{2}{*}{ Index for all outcomes } & 0.079 & 0.077 & -0.016 & $-0.116 *$ \\
\hline & $(0.062)$ & $(0.065)$ & $(0.062)$ & $(0.069)$ \\
\hline \multirow[t]{2}{*}{ Absence of physical health problems } & $0.109 *$ & $0.124 *$ & -0.075 & -0.058 \\
\hline & $(0.061)$ & $(0.065)$ & $(0.068)$ & $(0.078)$ \\
\hline \multirow[t]{2}{*}{ Absence of mental health problems } & $0.160 * * *$ & 0.039 & 0.008 & -0.062 \\
\hline & $(0.058)$ & $(0.065)$ & $(0.064)$ & $(0.071)$ \\
\hline \multirow[t]{2}{*}{ Absence of risky behavior } & -0.001 & 0.007 & 0.027 & -0.069 \\
\hline & $(0.065)$ & $(0.066)$ & $(0.061)$ & $(0.067)$ \\
\hline \multirow[t]{2}{*}{ Education } & -0.043 & 0.027 & -0.006 & -0.082 \\
\hline & $(0.061)$ & $(0.072)$ & $(0.061)$ & $(0.069)$ \\
\hline \multicolumn{5}{|c|}{ Panel B. Selected education outcomes by age group (z-scores) } \\
\hline \multirow{3}{*}{ Combined math and reading assessment } & \multicolumn{2}{|c|}{ Under Age 6 at Baseline } & \multicolumn{2}{|c|}{ Ages 6 and Over at Baseline } \\
\hline & -0.014 & 0.019 & -0.018 & 0.043 \\
\hline & $(0.055)$ & $(0.056)$ & $(0.061)$ & $(0.072)$ \\
\hline
\end{tabular}

Notes : Estimates are the intent-to-treat effect sizes from an ordinary least squares regression of each outcome on treatment indicators and the baseline covariates listed in Appendix Tables 1 and 1B. Robust standard errors adjusted for household clustering are in parentheses. All measures are z-scores using the mean and standard deviation for the control group. Index components are (positive outcomes (+) included as is, while signs for negative outcomes (-) were reversed so that higher values indicate "better" outcomes): Physical health: - self-reported health fair/poor - asthma attack past year - overweight - non-sports injury past year. Mental health: - distress - depression - Generalized Anxiety. Risky behavior: - marijuana past 30 days - smoking past 30 days - alcohol past 30 days - ever pregnant or gotten someone pregnant. Education: + graduated high school or still in school + in school or working + Early Childhood Longitudinal Study-Kindergarten cohort study (ECLS-K) reading score + ECLS-K math score. The index for all outcomes includes the 15 measures from the four indices. Source and Sample: The sample in both panels is youth who were interviewed as part of the long-term survey. Panel A is youth ages 15 -20 as of December 2007, and Panel B is youth ages 13-20 (in analysis not shown, effects for youth ages 10-12 were similar to those for ages 13-20). Sample sizes in the Experimental, Section 8, and Control groups are 1,437, 1,031, and 1,153 for Panel A and 1,850, 1,318, and 1,476 for Panel B.

*** Significant at the 1 percent level.

* Significant at the 10 percent level. 

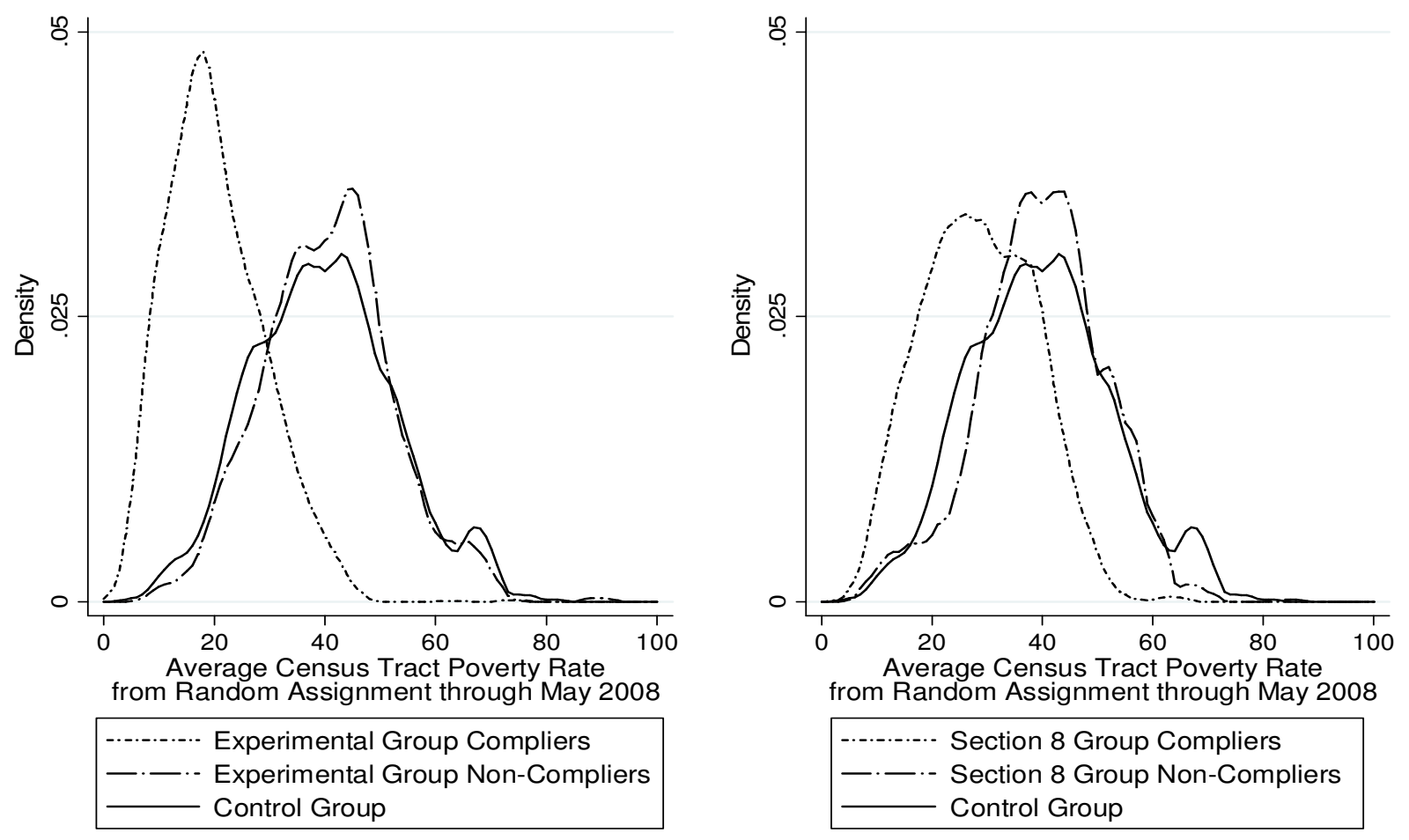

\section{APPENDIX FIGURE 1. DENSITIES OF AVERAGE POVERTY RATE BY TREATMENT GROUP}

Notes : Duration-weighted average of census tract poverty at all addresses from random assignment through May 2008 (just prior to the long-term survey fielding period), based on linear interpolation of 1990 and 2000 decennial census and the 2005-09 American Community Survey data. Density estimates used an Epanechnikov kernel with a half-width of 2. Source and Sample: The sample is all adults who were interviewed as part of the long-term survey. Sample sizes in the Experimental, Section 8, and control groups are 1,456, 678, and 1,139. 


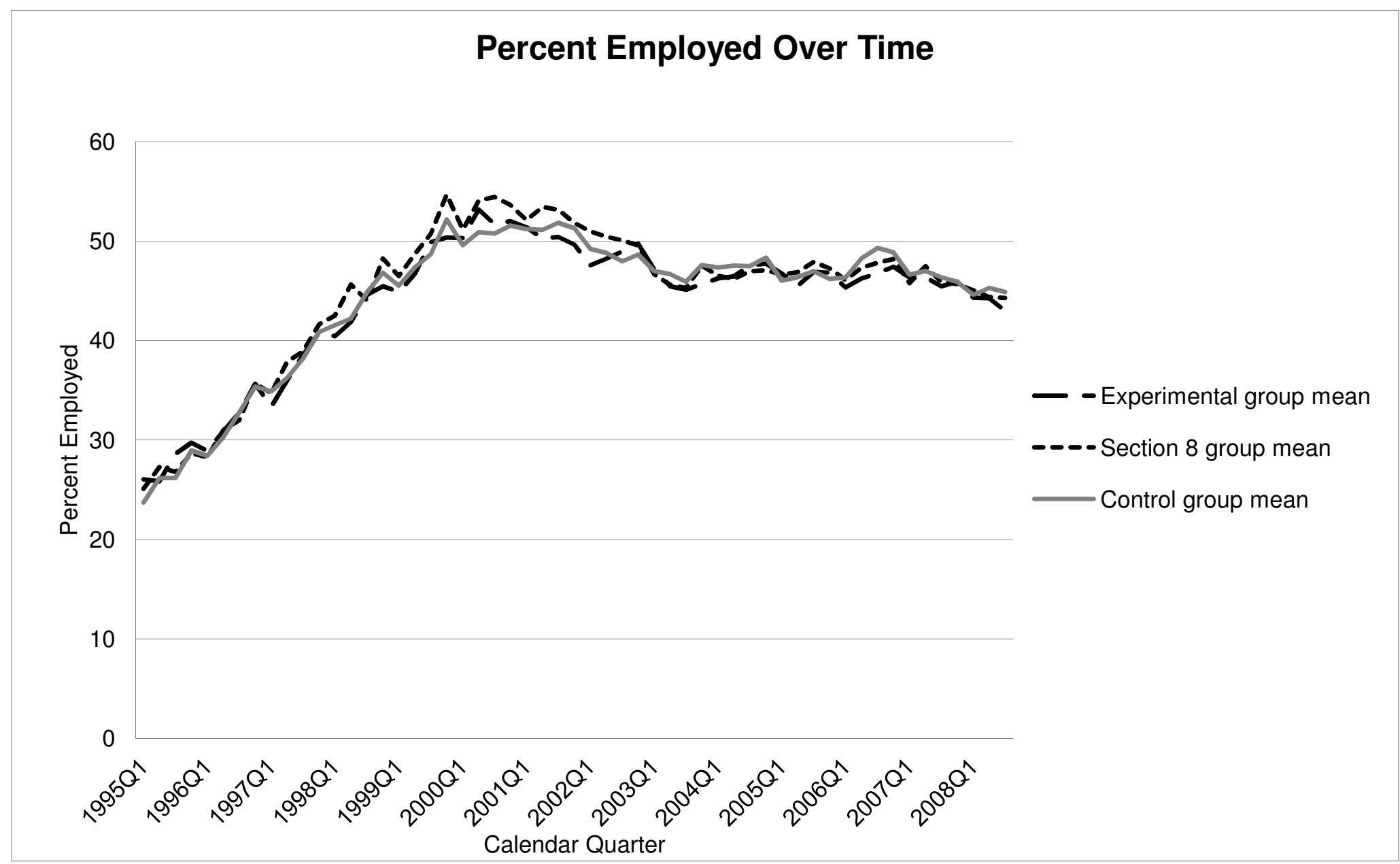

\section{APPENDIX FIGURE 2. EMPLOYMENT RATES OVER TIME BY TREATMENT GROUP}

Notes: Employment is the fraction with positive earnings per quarter.

Source and Sample: Data are from administrative Unemployment Insurance (UI) records. The analysis uses individual-level data from UI records from Maryland, Illinois, California, and Florida for individuals whose random assignment site was Baltimore, Chicago, or Los Angeles and aggregate-level UI data from Massachusetts and New York, representing individuals whose random assignment site was Boston or New York City. The sample is adults from all MTO households for whom consent to administrative data collection was available $(\mathrm{N}=4,194)$. 

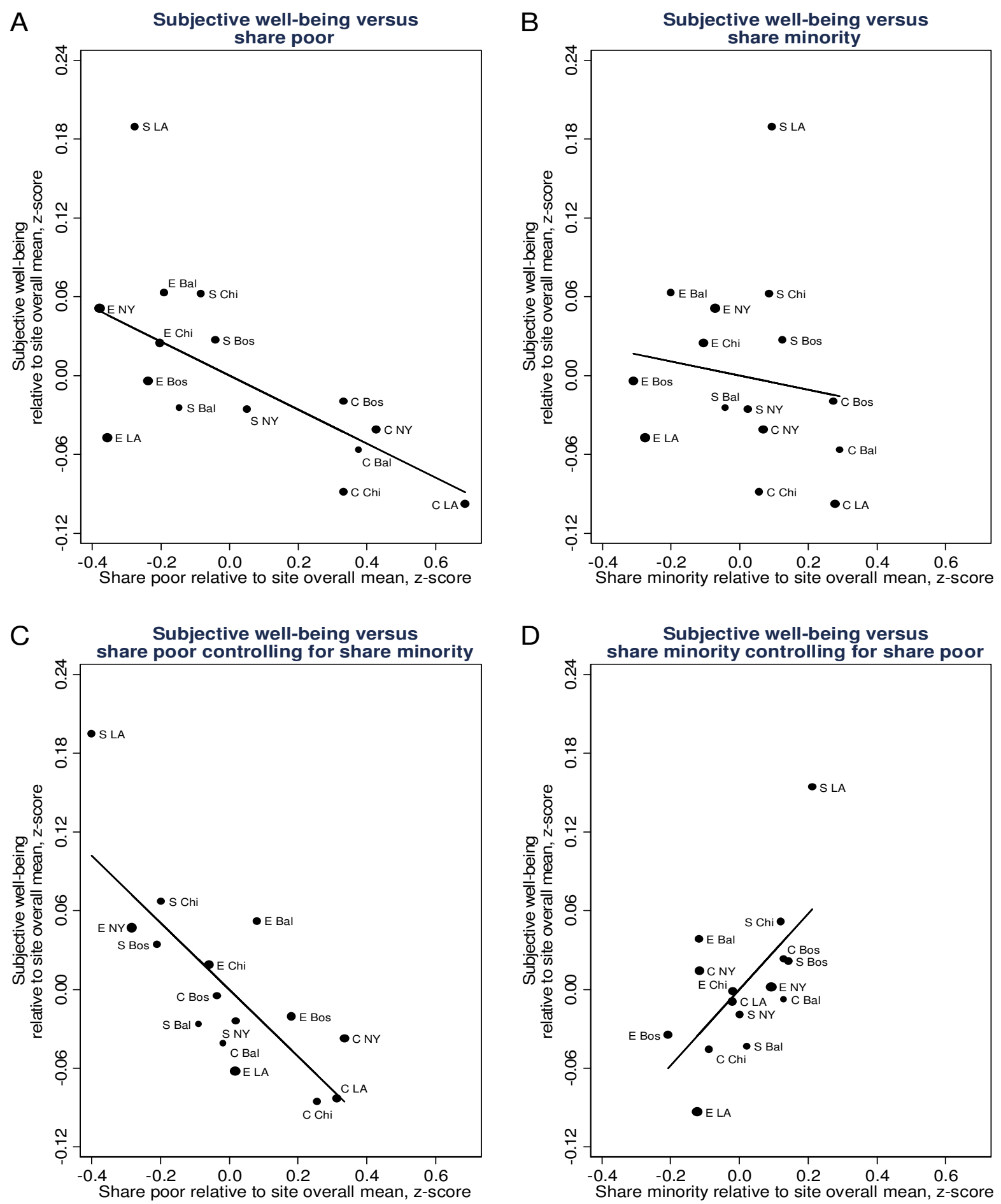

\section{APPENDIX FIGURE 3. INSTRUMENTAL VARIABLE ESTIMATION OF THE RELATIONSHIP BETWEEN SUBJECTIVE WELL-BEING AND TRACT POVERTY RATE AND TRACT SHARE MINORITY}


APPENDIX FIGURE 3. (continued)

Notes: The figure shows the instrumental variable estimation of the relationship between subjective well-being and average (duration-weighted) tract poverty rate (panel A), tract share minority (panel B), tract poverty controlling for share minority (panel C), and tract share minority share controlling for tract poverty (panel D). The y-axis is a 3-point happiness scale (1=not too happy, $2=$ pretty happy, $3=$ very happy) expressed in standard deviation units relative to the control group. Share poor is the fraction of census tract residents living below the poverty threshold. Share minority is the fraction of census tract residents who are members of racial or ethnic minority groups. Tract shares are linearly interpolated from the 1990 and 2000 decennial census and 2005-09 American Community Survey and are weighted by the time respondents lived at each of their addresses from random assignment through May 2008. Share poor and minority are z-scores, standardized by the control group mean and standard deviation. The points represent the site $(\mathrm{Bal}=$ Baltimore, Bos $=$ Boston, Chi $=$ Chicago, LA $=$ Los Angeles, $\mathrm{NY}=\mathrm{New}$ York City) and treatment group ( $\mathrm{E}=$ Experimental group, $\mathrm{S}=$ Section 8 group, $\mathrm{C}=$ control group). The slope of the line is equivalent to a 2SLS estimate of the relationship between subjective well-being and the mediator shown in each panel, using interactions of indicators for MTO treatment group assignment and demonstration site as instruments for the mediator (controlling for site indicator main effects). The estimated impact of 1 sd decrease in poverty (Panel A) is a 0.129 sd increase in $\mathrm{SWB}(\mathrm{SE}=0.054, \mathrm{P}=0.017)$, and The estimated impact of $1 \mathrm{sd}$ decrease in poverty controlling for minority share (Panel C) is a 0.255 sd increase in $\mathrm{SWB}(\mathrm{SE}=0.095, \mathrm{P}=0.008)$, and the estimated impact of $1 \mathrm{sd}$ decrease in minority share controlling for poverty (Panel D) is a 0.289sd decrease in $\mathrm{SWB}(\mathrm{SE}=0.176, \mathrm{P}=0.101)$. The p-value from an $\mathrm{F}$ test of whether the coefficients on poverty and minority share are the same (that is, whether the slope in panel C equals the slope in panel $\mathrm{D}$ ) is 0.036 .

Source and Sample: The sample is all adults who were interviewed as part of the long-term survey with non-missing subjective well-being and duration-weighted census tract characteristics data $(\mathrm{N}=3,263)$. 
APPENDIX TABLE 1

BASELINE CHARACTERISTICS (1994-98) CONTROLLED FOR IN THE MAIN ANALYSIS

\begin{tabular}{cccc}
\hline \hline Control & Experimental & Section 8 \\
\hline $\mathrm{N}=1139$ & $\mathrm{~N}=1456$ & $\mathrm{~N}=678$
\end{tabular}

Female

0.978

$0.988 *$

0.978

Age as of December 31, 2007

$\leq 35$

0.143

0.145

0.132

$36-40$

0.229

0.212

0.236

41-45

0.234

0.236

0.223

46-50

0.175

0.184

0.203

$>50$

0.249

0.251

0.240

Race and ethnicity

African-American (any ethnicity)

0.660

0.648

0.629

Other non-white (any ethnicity)

0.270

0.283

0.283

Hispanic ethnicity (any race)

0.304

0.314

0.340

Other demographic characteristics

Never married

0.637

0.623

0.624

Parent before age 18

0.246

0.249

0.277

0.245

0.271

0.269

Enrolled in school

0.167

0.161

0.174

High school diploma

0.361

0.381

0.347

Certificate of General Educational

Development (GED)

0.199

$0.159 * *$

0.183

Receiving Aid to Families with Dependent

Children (AFDC)

0.763

0.763

0.736

\section{Household characteristics}

Own car

0.170

0.190

0.190

Disabled household member

0.148

0.145

0.168

No teens in household

0.646

$0.608 *$

0.610

Household size

Two

0.194

0.223

0.210

Three

0.330

0.302

0.291

Four or more

0.221

0.233

0.238 
APPENDIX TABLE 1 (continued)

\begin{tabular}{|c|c|c|c|}
\hline & Control & Experimental & Section 8 \\
\hline \multicolumn{4}{|l|}{ Site } \\
\hline Baltimore & 0.135 & 0.134 & 0.140 \\
\hline Boston & 0.205 & 0.201 & 0.207 \\
\hline Chicago & 0.205 & 0.205 & 0.209 \\
\hline Los Angeles & 0.226 & 0.233 & 0.214 \\
\hline New York & 0.229 & 0.227 & 0.231 \\
\hline $\begin{array}{l}\text { Neighborhood characteristics } \\
\text { Household member was crime victim in } \\
\text { last six months }\end{array}$ & 0.416 & 0.434 & 0.414 \\
\hline Streets unsafe at night & 0.512 & 0.493 & 0.517 \\
\hline Very dissatisfied with neighborhood & 0.467 & 0.478 & 0.477 \\
\hline Lived in neighborhood $5+$ years & 0.606 & 0.599 & 0.616 \\
\hline Moved more than 3 times in past 5 years & 0.108 & 0.093 & 0.090 \\
\hline No family in neighborhood & 0.639 & 0.640 & 0.611 \\
\hline No friends in neighborhood & 0.409 & 0.396 & 0.400 \\
\hline $\begin{array}{l}\text { Chatted with neighbors at least once per } \\
\text { week }\end{array}$ & 0.549 & 0.524 & $0.486 * *$ \\
\hline $\begin{array}{l}\text { Very likely to tell neighbor about child } \\
\text { getting into trouble }\end{array}$ & 0.555 & 0.556 & 0.521 \\
\hline Confident about finding a new apartment & 0.456 & 0.477 & 0.499 \\
\hline Had Section 8 voucher before & 0.426 & 0.400 & $0.379 *$ \\
\hline \multicolumn{4}{|l|}{$\begin{array}{l}\text { Primary or secondary reason for } \\
\text { wanting to move }\end{array}$} \\
\hline To get away from gangs and drugs & 0.779 & 0.786 & 0.749 \\
\hline Better schools for children & 0.481 & 0.491 & $0.553 * * *$ \\
\hline \multicolumn{4}{|c|}{$\begin{array}{l}\text { Notes: All values represent shares. Values are calculated using sample weights to account for changes in } \\
\text { random assignment ratios across randomization cohorts, for survey sample selection, and for two-phase } \\
\text { interviewing. Missing values were imputed based on randomization site and whether randomized through } \\
1997 \text { or in } 1998 \text {. The baseline head of household reported on the neighborhood characteristics listed } \\
\text { here. Analysis control variables not listed include whether the adult was part of the first survey release } \\
\text { and whether education level is missing. An omnibus F-test fails to reject the null hypothesis that the set } \\
\text { of baseline characteristics presented above is the same for both the control group and the randomly } \\
\text { assigned housing voucher treatment groups (p-value for the Experimental vs. control comparison is } \\
\mathrm{P}=0.442 \text {; and p-value for the Section } 8 \text { vs. control comparison is } \mathrm{P}=0.229 \text { ). } \\
\text { Source and Sample: Baseline survey. The sample is all adults interviewed as part of the long-term } \\
\text { survey (N=3,273). } \\
\text { *** Significant at the } 1 \text { percent level on an independent group t-test of the difference between the control } \\
\text { group and the Experimental group or the Section } 8 \text { group. } \\
\text { ** Significant at the } 5 \text { percent level. } \\
\text { * Significant at the } 10 \text { percent level. }\end{array}$} \\
\hline
\end{tabular}


APPENDIX TABLE 1B

ADDITIONAL BASELINE CHARACTERISTICS CONTROLLED FOR IN THE YOUTH ANALYSIS

\begin{tabular}{|c|c|c|c|}
\hline & Control & Experimental & Section 8 \\
\hline & $\mathrm{N}=1153$ & $\mathrm{~N}=1437$ & $\mathrm{~N}=1031$ \\
\hline Male & 0.513 & 0.480 & 0.495 \\
\hline \multicolumn{4}{|l|}{ Age as of December 31, 2007} \\
\hline 15 & 0.150 & 0.166 & 0.161 \\
\hline 16 & 0.183 & 0.180 & 0.169 \\
\hline 17 & 0.182 & 0.189 & 0.162 \\
\hline 18 & 0.160 & $0.191 * *$ & 0.167 \\
\hline 19 & 0.172 & $0.138 * *$ & 0.155 \\
\hline 20 & 0.154 & 0.135 & $0.185 *$ \\
\hline Age 6 or over at baseline & 0.562 & 0.534 & 0.566 \\
\hline \multicolumn{4}{|l|}{ Older youth characteristics } \\
\hline Gifted student or did advanced coursework & 0.145 & 0.123 & 0.129 \\
\hline $\begin{array}{l}\text { Suspended or expelled from school in past two } \\
\text { years }\end{array}$ & 0.032 & 0.031 & 0.041 \\
\hline School called about behavior in past two years & 0.196 & 0.200 & 0.218 \\
\hline Behavioral or emotional problems & 0.061 & 0.051 & 0.059 \\
\hline Learning problems & 0.134 & 0.101 & 0.137 \\
\hline \multicolumn{4}{|l|}{ Younger youth characteristics } \\
\hline In hospital before first birthday & 0.201 & 0.169 & 0.179 \\
\hline Weighed less than 6 pounds at birth & 0.153 & 0.116 & 0.152 \\
\hline Adult read to youth more than once per day & 0.236 & 0.241 & 0.184 \\
\hline \multicolumn{4}{|l|}{ All youth characteristics } \\
\hline Health problems that limited activity & 0.058 & 0.060 & 0.057 \\
\hline $\begin{array}{l}\text { Health problems that required special medicine } \\
\text { or equipment }\end{array}$ & 0.081 & 0.081 & 0.096 \\
\hline
\end{tabular}

Notes : All values represent shares. Values are calculated using sample weights to account for changes in random assignment ratios across randomization cohorts, for survey sample selection, and for two-phase interviewing. Missing values were imputed based on randomization site and whether randomized through 1997 or in 1998. The baseline head of household reported on all youth characteristics listed here. At baseline, older youth were ages 6 to 11 and younger youth were ages 0 to 5 . The youth analysis includes all control variables listed in Appendix Table 1 (except for the survey release flag) as well as those listed in this table and flags for missing data for several characteristics listed above (gifted student, suspended/expelled, behavioral problems, learning problems, hospitalization, low birth weight, read to by household member, activity-limiting health problems).

Source and Sample: Baseline survey. The sample is all youth ages 15-20 as of December 2007 interviewed as part of the long-term survey $(\mathrm{N}=3,621)$.

** Significant at the 5 percent level on an independent group t-test of the difference between the control group and the Experimental group or the Section 8 group.

* Significant at the 10 percent level. 
APPENDIX TABLE 2 - EFFECTS ON EXPANDED SET OF HOUSING AND NEIGHBORHOOD CONDITION MEASURES

\begin{tabular}{|c|c|c|c|c|c|c|c|c|c|c|}
\hline & \multirow[b]{2}{*}{$\mathbf{C M}$} & \multicolumn{5}{|c|}{ Experimental vs. Control } & \multicolumn{4}{|c|}{ Section 8 vs. Control } \\
\hline & & ITT & & TOT & CCM & $\mathbf{N}$ & ITT & TOT & CCM & $\mathbf{N}$ \\
\hline \multicolumn{11}{|l|}{ Tract share poor } \\
\hline \multicolumn{11}{|l|}{ At baseline } \\
\hline Share poor & 0.531 & $\begin{array}{r}-0.004 \\
(0.005)\end{array}$ & & $\begin{array}{r}-0.009 \\
(0.009)\end{array}$ & 0.539 & 2555 & $\begin{array}{r}-0.003 \\
(0.006)\end{array}$ & $\begin{array}{r}-0.004 \\
(0.010)\end{array}$ & 0.544 & 1797 \\
\hline Share poor, z-score on U.S. tracts & 3.172 & $\begin{array}{r}-0.036 \\
(0.037)\end{array}$ & & $\begin{array}{r}-0.074 \\
(0.076)\end{array}$ & 3.241 & 2555 & $\begin{array}{r}-0.021 \\
(0.049)\end{array}$ & $\begin{array}{r}-0.034 \\
(0.079)\end{array}$ & 3.280 & 1797 \\
\hline Share poor, z-score on MTO controls & 0.000 & $\begin{array}{r}-0.030 \\
(0.031)\end{array}$ & & $\begin{array}{r}-0.062 \\
(0.063)\end{array}$ & 0.057 & 2555 & $\begin{array}{r}-0.018 \\
(0.041)\end{array}$ & $\begin{array}{r}-0.028 \\
(0.065)\end{array}$ & 0.089 & 1797 \\
\hline \multicolumn{11}{|l|}{1 year post-random assignment } \\
\hline Share poor & 0.499 & $\begin{array}{r}-0.169 \\
(0.008)\end{array}$ & $* * *$ & $\begin{array}{l}-0.352 * * * \\
(0.013)\end{array}$ & 0.507 & 2552 & $\begin{array}{l}-0.134 * * * \\
(0.009)\end{array}$ & $\begin{array}{l}-0.213 * * * \\
(0.013)\end{array}$ & 0.505 & 1793 \\
\hline Share poor, z-score on U.S. tracts & 2.916 & $\begin{array}{r}-1.372 \\
(0.062)\end{array}$ & $* * *$ & $\begin{array}{l}-2.853 * * * \\
(0.102)\end{array}$ & 2.982 & 2552 & $\begin{array}{l}-1.085 * * * \\
(0.073)\end{array}$ & $\begin{array}{l}-1.728 * * * \\
(0.102)\end{array}$ & 2.965 & 1793 \\
\hline Share poor, z-score on MTO controls & 0.000 & $\begin{array}{r}-1.043 \\
(0.047)\end{array}$ & $* * *$ & $\begin{array}{l}-2.168 * * * \\
(0.077)\end{array}$ & 0.050 & 2552 & $\begin{array}{l}-0.825 * * * \\
(0.056)\end{array}$ & $\begin{array}{l}-1.313 * * * \\
(0.077)\end{array}$ & 0.037 & 1793 \\
\hline \multicolumn{11}{|l|}{5 years post-random assignment } \\
\hline Share poor & 0.399 & $\begin{array}{r}-0.098 \\
(0.007)\end{array}$ & $* * *$ & $\begin{array}{l}-0.202 * * * \\
(0.014)\end{array}$ & 0.390 & 2544 & $\begin{array}{l}-0.065 * * * \\
(0.010)\end{array}$ & $\begin{array}{l}-0.104 * * * \\
(0.016)\end{array}$ & 0.392 & 1785 \\
\hline Share poor, z-score on U.S. tracts & 2.109 & $\begin{array}{r}-0.793 \\
(0.060)\end{array}$ & $* * *$ & $\begin{array}{l}-1.634 * * * \\
(0.110)\end{array}$ & 2.030 & 2544 & $\begin{array}{l}-0.526 * * * \\
(0.083)\end{array}$ & $\begin{array}{l}-0.842 * * * \\
(0.131)\end{array}$ & 2.052 & 1785 \\
\hline Share poor, z-score on MTO controls & 0.000 & $\begin{array}{r}-0.594 \\
(0.045)\end{array}$ & $* * *$ & $\begin{array}{l}-1.225 * * * \\
(0.083)\end{array}$ & -0.059 & 2544 & $\begin{array}{l}-0.394 * * * \\
(0.062)\end{array}$ & $\begin{array}{l}-0.631 * * * \\
(0.098)\end{array}$ & -0.042 & 1785 \\
\hline \multicolumn{11}{|l|}{$\begin{array}{l}\text { 10-15 years post-random assignment } \\
\text { (May 2008) }\end{array}$} \\
\hline Share poor & 0.311 & $\begin{array}{r}-0.037 \\
(0.007)\end{array}$ & $* * *$ & $\begin{array}{l}-0.076 * * * \\
(0.014)\end{array}$ & 0.285 & 2549 & $\begin{array}{l}-0.021 * * \\
(0.010)\end{array}$ & $\begin{array}{l}-0.034 * * \\
(0.016)\end{array}$ & 0.276 & 1778 \\
\hline Share poor, z-score on U.S. tracts & 1.396 & $\begin{array}{r}-0.298 \\
(0.057)\end{array}$ & $* * *$ & $\begin{array}{l}-0.618 * * * \\
(0.115)\end{array}$ & 1.183 & 2549 & $(0.080)$ & $\begin{array}{l}-0.275 * * \\
(0.127)\end{array}$ & 1.108 & 1778 \\
\hline Share poor, z-score on MTO controls & 0.000 & $\begin{array}{r}-0.220 \\
(0.042)\end{array}$ & $* * *$ & $\begin{array}{l}-0.456 * * * \\
(0.085)\end{array}$ & -0.157 & 2549 & $\begin{array}{l}-0.126 * * \\
(0.059)\end{array}$ & $\begin{array}{l}-0.203 * * \\
(0.094)\end{array}$ & -0.212 & 1778 \\
\hline
\end{tabular}




\begin{tabular}{|c|c|c|c|c|c|c|c|c|c|c|}
\hline & \multirow[b]{2}{*}{$\mathbf{C M}$} & \multicolumn{5}{|c|}{ Experimental vs. Control } & \multicolumn{4}{|c|}{ Section 8 vs. Control } \\
\hline & & ITT & & TOT & CCM & $\mathbf{N}$ & ITT & TOT & CCM & $\mathbf{N}$ \\
\hline \multicolumn{11}{|l|}{ Tract share poor (continued) } \\
\hline \multicolumn{11}{|l|}{ Duration-weighted } \\
\hline Share poor & 0.396 & $\begin{array}{r}-0.088 \\
(0.006)\end{array}$ & $* * *$ & $\begin{array}{l}-0.183 * * * \\
(0.010)\end{array}$ & 0.383 & 2592 & $\begin{array}{l}-0.062 * * * \\
(0.007)\end{array}$ & $\begin{array}{l}-0.099 * * * \\
(0.011)\end{array}$ & 0.384 & 1817 \\
\hline Share poor, z-score on U.S. tracts & 2.082 & $\begin{array}{r}-0.716 \\
(0.046)\end{array}$ & $* * *$ & $\begin{array}{l}-1.482 * * * \\
(0.080)\end{array}$ & 1.974 & 2592 & $\begin{array}{l}-0.501 * * * \\
(0.058)\end{array}$ & $\begin{array}{l}-0.800 * * * \\
(0.088)\end{array}$ & 1.985 & 1817 \\
\hline Share poor, z-score on MTO controls & 0.000 & $\begin{array}{r}-0.702 \\
(0.045)\end{array}$ & $* * *$ & $\begin{array}{l}-1.454 * * * \\
(0.078)\end{array}$ & -0.107 & 2592 & $\begin{array}{l}-0.491 * * * \\
(0.057)\end{array}$ & $\begin{array}{l}-0.785 * * * \\
(0.086)\end{array}$ & -0.095 & 1817 \\
\hline \multicolumn{11}{|l|}{ Duration-weighted poverty rate is... } \\
\hline Less than $20 \%$ & 0.054 & $\begin{array}{r}0.233 \\
(0.015)\end{array}$ & $* * *$ & $\begin{array}{l}0.483 * * * \\
(0.026)\end{array}$ & 0.076 & 2592 & $\begin{array}{l}0.104 * * * \\
(0.019)\end{array}$ & $\begin{array}{l}0.165 * * * \\
(0.030)\end{array}$ & 0.066 & 1817 \\
\hline Less than $30 \%$ & 0.242 & $\begin{array}{r}0.268 \\
(0.019)\end{array}$ & *** & $\begin{array}{l}0.555 * * * \\
(0.035)\end{array}$ & 0.310 & 2592 & $\begin{array}{l}0.148 \text { *** } \\
(0.027)\end{array}$ & $\begin{array}{l}0.236 * * * \\
(0.043)\end{array}$ & 0.317 & 1817 \\
\hline Less than $40 \%$ & 0.512 & $\begin{array}{r}0.199 \\
(0.020)\end{array}$ & $* * *$ & $\begin{array}{l}0.412 \text { **** } \\
(0.038)\end{array}$ & 0.568 & 2592 & $\begin{array}{l}0.207 * * * \\
(0.028)\end{array}$ & $\begin{array}{l}0.331 * * * \\
(0.043)\end{array}$ & 0.532 & 1817 \\
\hline \multicolumn{11}{|l|}{ Tract share minority } \\
\hline \multicolumn{11}{|l|}{ At baseline } \\
\hline Share minority & 0.912 & $\begin{array}{r}0.001 \\
(0.007)\end{array}$ & & $\begin{array}{r}0.003 \\
(0.014)\end{array}$ & 0.909 & 2555 & $\begin{array}{r}0.007 \\
(0.010)\end{array}$ & $\begin{array}{r}0.011 \\
(0.016)\end{array}$ & 0.895 & 1797 \\
\hline Share minority, z-score on U.S. tracts & 1.898 & $\begin{array}{r}0.005 \\
(0.021)\end{array}$ & & $\begin{array}{r}0.010 \\
(0.045)\end{array}$ & 1.889 & 2555 & $\begin{array}{r}0.023 \\
(0.032)\end{array}$ & $\begin{array}{r}0.036 \\
(0.051)\end{array}$ & 1.845 & 1797 \\
\hline $\begin{array}{l}\text { Share minority, z-score on MTO } \\
\text { controls }\end{array}$ & 0.000 & $\begin{array}{r}0.008 \\
(0.035)\end{array}$ & & $\begin{array}{r}0.016 \\
(0.073)\end{array}$ & -0.015 & 2555 & $\begin{array}{r}0.037 \\
(0.052)\end{array}$ & $\begin{array}{r}0.059 \\
(0.084)\end{array}$ & -0.088 & 1797 \\
\hline \multicolumn{11}{|l|}{1 year post-random assignment } \\
\hline Share minority & 0.904 & $\begin{array}{r}-0.111 \\
(0.009)\end{array}$ & $* * *$ & $\begin{array}{l}-0.230 * * * \\
(0.017)\end{array}$ & 0.897 & 2552 & $\begin{array}{l}-0.031 * * * \\
(0.011)\end{array}$ & $\begin{array}{l}-0.049 * * * \\
(0.018)\end{array}$ & 0.881 & 1793 \\
\hline Share minority, z-score on U.S. tracts & 1.875 & $\begin{array}{r}-0.356 \\
(0.028)\end{array}$ & $* * *$ & $\begin{array}{l}-0.740 * * * \\
(0.054)\end{array}$ & 1.852 & 2552 & $\begin{array}{l}-0.098 * * * \\
(0.036)\end{array}$ & $\begin{array}{l}-0.156 * * * \\
(0.057)\end{array}$ & 1.802 & 1793 \\
\hline $\begin{array}{l}\text { Share minority, z-score on MTO } \\
\text { controls }\end{array}$ & 0.000 & $\begin{array}{r}-0.574 \\
(0.045)\end{array}$ & $* * *$ & $\begin{array}{l}-1.194 * * * \\
(0.086)\end{array}$ & -0.036 & 2552 & $\begin{array}{l}-0.158 * * * \\
(0.058)\end{array}$ & $\begin{array}{l}-0.252 * * * \\
(0.092)\end{array}$ & -0.118 & 1793 \\
\hline
\end{tabular}




\begin{tabular}{|c|c|c|c|c|c|c|c|c|c|c|}
\hline & \multirow[b]{2}{*}{$\mathbf{C M}$} & \multicolumn{5}{|c|}{ Experimental vs. Control } & \multicolumn{4}{|c|}{ Section 8 vs. Control } \\
\hline & & ITT & & TOT & CCM & $\mathbf{N}$ & ITT & TOT & CCM & $\mathbf{N}$ \\
\hline \multicolumn{11}{|l|}{ Tract share minority (continued) } \\
\hline \multicolumn{11}{|l|}{5 years post-random assignment } \\
\hline Share minority & 0.886 & $\begin{array}{r}-0.056 \\
(0.009)\end{array}$ & $* * *$ & $\begin{array}{l}-0.116 * * * \\
(0.017)\end{array}$ & 0.868 & 2544 & $\begin{array}{r}-0.014 \\
(0.012)\end{array}$ & $\begin{array}{r}-0.023 \\
(0.019)\end{array}$ & 0.868 & 1785 \\
\hline Share minority, z-score on U.S. tracts & 1.815 & $\begin{array}{r}-0.181 \\
(0.028)\end{array}$ & $* * *$ & $\begin{array}{l}-0.374 * * * \\
(0.055)\end{array}$ & 1.760 & 2544 & $\begin{array}{r}-0.046 \\
(0.038)\end{array}$ & $\begin{array}{r}-0.074 \\
(0.061)\end{array}$ & 1.759 & 1785 \\
\hline $\begin{array}{l}\text { Share minority, z-score on MTO } \\
\text { controls }\end{array}$ & 0.000 & $\begin{array}{r}-0.285 \\
(0.043)\end{array}$ & $* * *$ & $\begin{array}{l}-0.588 * * * \\
(0.086)\end{array}$ & -0.086 & 2544 & $\begin{array}{r}-0.072 \\
(0.060)\end{array}$ & $\begin{array}{r}-0.116 \\
(0.096)\end{array}$ & -0.088 & 1785 \\
\hline \multicolumn{11}{|l|}{$\begin{array}{l}\text { 10-15 years post-random assignment } \\
\text { (May 2008) }\end{array}$} \\
\hline Share minority & 0.844 & $\begin{array}{r}-0.036 \\
(0.010)\end{array}$ & $* * *$ & $\begin{array}{l}-0.075 * * * \\
(0.021)\end{array}$ & 0.856 & 2549 & $\begin{array}{r}0.004 \\
(0.015)\end{array}$ & $\begin{array}{r}0.007 \\
(0.024)\end{array}$ & 0.812 & 1778 \\
\hline Share minority, z-score on U.S. tracts & 1.681 & $\begin{array}{r}-0.115 \\
(0.032)\end{array}$ & $* * *$ & $\begin{array}{l}-0.239 * * * \\
(0.066)\end{array}$ & 1.719 & 2549 & $\begin{array}{r}0.013 \\
(0.048)\end{array}$ & $\begin{array}{r}0.022 \\
(0.077)\end{array}$ & 1.578 & 1778 \\
\hline $\begin{array}{l}\text { Share minority, z-score on MTO } \\
\text { controls }\end{array}$ & 0.000 & $\begin{array}{r}-0.157 \\
(0.043)\end{array}$ & $* * *$ & $\begin{array}{l}-0.325 * * * \\
(0.090)\end{array}$ & 0.051 & 2549 & $\begin{array}{r}0.018 \\
(0.065)\end{array}$ & $\begin{array}{r}0.029 \\
(0.104)\end{array}$ & -0.140 & 1778 \\
\hline \multicolumn{11}{|l|}{ Duration-weighted } \\
\hline Share minority & 0.880 & $\begin{array}{r}-0.060 \\
(0.007)\end{array}$ & $* * *$ & $\begin{array}{l}-0.123 * * * \\
(0.013)\end{array}$ & 0.873 & 2592 & $\begin{array}{r}-0.010 \\
(0.010)\end{array}$ & $\begin{array}{r}-0.016 \\
(0.015)\end{array}$ & 0.857 & 1817 \\
\hline Share minority, z-score on U.S. tracts & 1.798 & $\begin{array}{r}-0.191 \\
(0.022)\end{array}$ & $* * *$ & $\begin{array}{l}-0.396 * * * \\
(0.043)\end{array}$ & 1.775 & 2592 & $\begin{array}{r}-0.033 \\
(0.031)\end{array}$ & $\begin{array}{r}-0.052 \\
(0.049)\end{array}$ & 1.723 & 1817 \\
\hline $\begin{array}{l}\text { Share minority, z-score on MTO } \\
\text { controls }\end{array}$ & 0.000 & $\begin{array}{r}-0.368 \\
(0.042)\end{array}$ & $* * *$ & $\begin{array}{l}-0.763 * * * \\
(0.083)\end{array}$ & -0.044 & 2592 & $\begin{array}{r}-0.063 \\
(0.059)\end{array}$ & $\begin{array}{r}-0.100 \\
(0.094)\end{array}$ & -0.143 & 1817 \\
\hline \multicolumn{11}{|l|}{ Other tract characteristics } \\
\hline \multicolumn{11}{|l|}{$\begin{array}{l}\text { 10-15 years post-random assignment } \\
\text { (May 2008) }\end{array}$} \\
\hline Concentrated disadvantage index & 1.128 & $\begin{array}{r}-0.104 \\
(0.018)\end{array}$ & $* * *$ & $\begin{array}{l}-0.215 * * * \\
(0.036)\end{array}$ & 1.077 & 2549 & $\begin{array}{l}-0.053 * * \\
(0.025)\end{array}$ & $\begin{array}{l}-0.085 * * \\
(0.039)\end{array}$ & 1.047 & 1778 \\
\hline $\begin{array}{l}\text { Concentrated disadvantage index, } \\
\text { Z-score on MTO controls }\end{array}$ & 0.000 & $\begin{array}{r}-0.245 \\
(0.042)\end{array}$ & $* * *$ & $\begin{array}{l}-0.508 * * * \\
(0.085)\end{array}$ & -0.119 & 2549 & $\begin{array}{l}-0.125 * * \\
(0.058)\end{array}$ & $\begin{array}{l}-0.201 * * \\
(0.093)\end{array}$ & -0.190 & 1778 \\
\hline Share college graduates & 0.220 & $\begin{array}{r}0.021 \\
(0.006)\end{array}$ & $* * *$ & $\begin{array}{l}0.043 * * * \\
(0.012)\end{array}$ & 0.211 & 2549 & $\begin{array}{r}0.003 \\
(0.009)\end{array}$ & $\begin{array}{r}0.005 \\
(0.014)\end{array}$ & 0.241 & 1778 \\
\hline
\end{tabular}




\begin{tabular}{|c|c|c|c|c|c|c|c|c|c|c|c|}
\hline & \multirow[b]{2}{*}{$\mathbf{C M}$} & \multicolumn{6}{|c|}{ Experimental vs. Control } & \multicolumn{4}{|c|}{ Section 8 vs. Control } \\
\hline & & ITT & & TOT & & $\mathbf{C C M}$ & $\mathbf{N}$ & ITT & TOT & CCM & $\mathbf{N}$ \\
\hline \multicolumn{12}{|l|}{ Other tract characteristics (continued) } \\
\hline \multicolumn{12}{|l|}{ Duration-weighted } \\
\hline Concentrated disadvantage index & 1.389 & $\begin{array}{r}-0.235 \\
(0.016)\end{array}$ & $* * *$ & $\begin{array}{r}-0.487 \\
(0.028)\end{array}$ & $* * *$ & 1.345 & 2592 & $\begin{array}{l}-0.171 * * * \\
(0.020)\end{array}$ & $\begin{array}{l}-0.273 * * * \\
(0.030)\end{array}$ & 1.362 & 1817 \\
\hline $\begin{array}{l}\text { Concentrated disadvantage index, } \\
\text { Z-score on MTO controls }\end{array}$ & 0.000 & $\begin{array}{r}-0.637 \\
(0.042)\end{array}$ & $* * *$ & $\begin{array}{l}-1.319 \\
(0.075)\end{array}$ & $* * *$ & -0.122 & 2592 & $\begin{array}{l}-0.462 * * * \\
(0.053)\end{array}$ & $\begin{array}{l}-0.738 * * * \\
(0.081)\end{array}$ & -0.073 & 1817 \\
\hline Share college graduates & 0.161 & $\begin{array}{r}0.042 \\
(0.004)\end{array}$ & $* * *$ & $\begin{array}{r}0.087 \\
(0.008)\end{array}$ & $* * *$ & 0.159 & 2592 & $\begin{array}{l}0.014 * * \\
(0.005)\end{array}$ & $\begin{array}{l}0.022 * * \\
(0.009)\end{array}$ & 0.172 & 1817 \\
\hline \multicolumn{12}{|l|}{ Residential mobility } \\
\hline $\begin{array}{l}\text { Number of moves after random } \\
\text { assignment }\end{array}$ & 2.165 & $\begin{array}{r}0.555 \\
(0.073)\end{array}$ & $* * *$ & $\begin{array}{r}1.152 \\
(0.146)\end{array}$ & $* * *$ & 2.276 & 2595 & $\begin{array}{l}0.588 * * * \\
(0.103)\end{array}$ & $\begin{array}{l}0.940 * * * \\
(0.158)\end{array}$ & 2.511 & 1817 \\
\hline \multicolumn{12}{|l|}{ Local area violent crime rate (per } \\
\hline \multicolumn{12}{|l|}{100,000 residents) } \\
\hline At baseline & $4,082.4$ & $\begin{array}{r}-62.0 \\
(91.0)\end{array}$ & & $\begin{array}{r}-128.7 \\
(189.2)\end{array}$ & & $4,314.9$ & 2579 & $\begin{array}{r}9.2 \\
(124.4)\end{array}$ & $\begin{array}{r}14.7 \\
(198.8)\end{array}$ & $4,201.6$ & 1810 \\
\hline 1 year after random assignment & $3,603.0$ & $\begin{array}{r}-1,035.7 \\
(84.3)\end{array}$ & $* * *$ & $\begin{array}{r}-2,258.9 \\
(178.5)\end{array}$ & $* * *$ & $3,711.1$ & 2506 & $\begin{array}{l}-718.9 * * * \\
(105.5)\end{array}$ & $\begin{array}{l}-1,154.4 * * * \\
(164.5)\end{array}$ & $3,687.9$ & 1800 \\
\hline 5 years after random assignment & $2,480.4$ & $\begin{array}{r}-486.1 \\
(59.9)\end{array}$ & $* * *$ & $\begin{array}{r}-1,044.3 \\
(125.2)\end{array}$ & $* * *$ & $2,443.9$ & 2495 & $\begin{array}{l}-301.6 * * * \\
(76.2)\end{array}$ & $\begin{array}{l}-485.9 * * * \\
(123.0)\end{array}$ & $2,645.2$ & 1776 \\
\hline $\begin{array}{l}\text { 10-15 years post-random assignm } \\
\text { (May 2008) }\end{array}$ & $1,458.4$ & $\begin{array}{r}-95.4 \\
(35.4)\end{array}$ & $* * *$ & $\begin{array}{r}-203.8 \\
(75.1)\end{array}$ & $* * *$ & $1,342.8$ & 2436 & $\begin{array}{r}-13.1 \\
(53.6)\end{array}$ & $\begin{array}{r}-21.1 \\
(86.7)\end{array}$ & $1,461.2$ & 1746 \\
\hline Duration-weighted & $2,317.2$ & $\begin{array}{r}-401.9 \\
(40.4)\end{array}$ & $* * *$ & $\begin{array}{r}-833.2 \\
(81.1)\end{array}$ & $* * *$ & $2,317.9$ & 2594 & $\begin{array}{l}-277.3 * * * \\
(54.9)\end{array}$ & $\begin{array}{l}-443.1 * * * \\
(87.4)\end{array}$ & $2,454.8$ & 1817 \\
\hline \multicolumn{12}{|l|}{ Local area property crime rate (per } \\
\hline At baseline & $7,021.1$ & $\begin{array}{r}200.3 \\
(243.2)\end{array}$ & & $\begin{array}{r}415.7 \\
(504.6)\end{array}$ & & $6,739.8$ & 2577 & $\begin{array}{r}37.3 \\
(226.6)\end{array}$ & $\begin{array}{r}59.6 \\
(362.1)\end{array}$ & $7,342.0$ & 1809 \\
\hline 1 year after random assignment & $6,376.8$ & $\begin{array}{l}-666.6 \\
(247.5)\end{array}$ & $* * *$ & $\begin{array}{r}-1,424.9 \\
(527.1)\end{array}$ & $* * *$ & $5,984.8$ & 2537 & $\begin{array}{l}-618.7 * * * \\
(203.7)\end{array}$ & $\begin{array}{l}-993.6 * * * \\
(325.5)\end{array}$ & $6,732.6$ & 1803 \\
\hline 5 years after random assignment & $5,134.1$ & $\begin{array}{r}-276.9 \\
(124.2)\end{array}$ & $* *$ & $\begin{array}{r}-588.2 \\
(262.2)\end{array}$ & & $4,700.7$ & 2514 & $\begin{array}{r}-270.7 \\
(169.4)\end{array}$ & $\begin{array}{r}-434.2 \\
(271.3)\end{array}$ & $5,491.3$ & 1780 \\
\hline
\end{tabular}




\begin{tabular}{|c|c|c|c|c|c|c|c|c|c|c|}
\hline & \multirow[b]{2}{*}{$\mathbf{C M}$} & \multicolumn{5}{|c|}{ Experimental vs. Control } & \multicolumn{4}{|c|}{ Section 8 vs. Control } \\
\hline & & ITT & & TOT & $\mathrm{CCM}$ & $\mathbf{N}$ & ITT & TOT & $\mathrm{CCM}$ & $\mathbf{N}$ \\
\hline \multicolumn{11}{|l|}{ Local area property crime rate (per } \\
\hline \multicolumn{11}{|l|}{100,000 residents) (continued) } \\
\hline $\begin{array}{l}\text { 10-15 years post-random assignment } \\
\text { (May 2008) }\end{array}$ & $3,747.5$ & $\begin{array}{r}62.0 \\
(80.3)\end{array}$ & & $\begin{array}{r}131.8 \\
(171.1)\end{array}$ & $3,354.6$ & 2472 & $\begin{array}{r}38.2 \\
(124.3)\end{array}$ & $\begin{array}{r}61.6 \\
(200.1)\end{array}$ & $3,991.7$ & 1754 \\
\hline Duration-weighted & $4,821.2$ & $\begin{array}{r}-207.6 \\
(89.0)\end{array}$ & $* *$ & $\begin{array}{l}-430.3 * * \\
(183.4)\end{array}$ & $4,544.4$ & 2593 & $\begin{array}{l}-239.1 * * \\
(106.4)\end{array}$ & $\begin{array}{l}-382.1 * * \\
(170.4)\end{array}$ & $5,205.9$ & 1817 \\
\hline \multicolumn{11}{|l|}{$\begin{array}{l}\text { Safety, housing and neighborhood } \\
\text { problems, and social networks }\end{array}$} \\
\hline Feel unsafe during day & 0.196 & $\begin{array}{l}-0.036 \\
(0.016)\end{array}$ & $* *$ & $\begin{array}{l}-0.076 * * \\
(0.034)\end{array}$ & 0.200 & 2587 & $\begin{array}{l}-0.047 * * \\
(0.023)\end{array}$ & $\begin{array}{l}-0.075 * * \\
(0.036)\end{array}$ & 0.181 & 1812 \\
\hline Saw drugs used or sold in last 30 days & 0.310 & $\begin{array}{r}-0.062 \\
(0.019)\end{array}$ & $* * *$ & $\begin{array}{l}-0.128 * * * \\
(0.039)\end{array}$ & 0.316 & 2583 & $\begin{array}{r}-0.027 \\
(0.027)\end{array}$ & $\begin{array}{r}-0.042 \\
(0.043)\end{array}$ & 0.249 & 1798 \\
\hline Number of housing problems $(0-7)$ & 2.051 & $\begin{array}{r}-0.359 \\
(0.080)\end{array}$ & $* * *$ & $\begin{array}{l}-0.745 * * * \\
(0.166)\end{array}$ & 2.186 & 2593 & $\begin{array}{l}-0.395 * * * \\
(0.115)\end{array}$ & $\begin{array}{l}-0.626 * * * \\
(0.181)\end{array}$ & 1.932 & 1812 \\
\hline $\begin{array}{l}\text { Likely or very likely to report kids } \\
\text { spraying graffiti (collective efficacy) }\end{array}$ & 0.589 & $\begin{array}{r}0.078 \\
(0.021)\end{array}$ & $* * *$ & $\begin{array}{l}0.162 * * * \\
(0.043)\end{array}$ & 0.541 & 2581 & $\begin{array}{r}0.018 \\
(0.030)\end{array}$ & $\begin{array}{r}0.028 \\
(0.048)\end{array}$ & 0.611 & 1807 \\
\hline $\begin{array}{l}\text { One or more friends with college } \\
\text { degree }\end{array}$ & 0.532 & $\begin{array}{r}0.071 \\
(0.021)\end{array}$ & $* * *$ & $\begin{array}{l}0.146 * * * \\
(0.044)\end{array}$ & 0.481 & 2543 & $\begin{array}{r}-0.018 \\
(0.031)\end{array}$ & $\begin{array}{l}-0.028 \\
(0.050)\end{array}$ & 0.583 & 1778 \\
\hline
\end{tabular}

Notes : CM, control mean; ITT, intent-to-treat, from ordinary least squares regression; TOT, treatment-on-treated, from two-stage least squares regression instrumenting treatment compliance; CCM, control complier mean. The estimated equations all include treatment indicators and the baseline covariates listed in Appendix Table 1. Robust standard errors are in parentheses. The concentrated disadvantage index is a weighted combination of census tract percent [i] poverty, [ii] on welfare, [iii] unemployed, [iv] female-headed family households, and [v] under age 18, with loading factors developed using 2000 Census tracts in Chicago by Sampson, Sharkey, and Raudenbush (2008), but does not include percent African-American. The local area crime rate data were refined after the publication of Ludwig (2012), but these results do not substantively differ from those in the earlier publication. The safety measure reflects whether the respondent felt unsafe or very unsafe (vs. safe or very safe) in the neighborhood during the day. Housing problems include peeling paint, broken plumbing, rats, roaches, broken locks, broken windows, and broken heating system. Source and Sample: Self-reported measures come from the adult long-term survey. Census tract characteristics are interpolated data from the 1990 and 2000 decennial censuses as well as the 2005-09 American Community Survey. The sample is all adults interviewed as part of the long-term survey ( $\mathrm{N}=3,273)$.

*** Significant at the 1 percent level.

** Significant at the 5 percent level. 
APPENDIX TABLE 3 - INTENT-TO-TREAT EFFECTS ON SUMMARY MEASURES OF OUTCOMES

\begin{tabular}{|c|c|c|c|c|c|c|c|c|c|c|}
\hline & \multicolumn{2}{|c|}{ All Adults } & \multicolumn{2}{|c|}{ All Youth } & \multicolumn{2}{|c|}{ Female Youth } & \multicolumn{2}{|c|}{ Male Youth } & \multicolumn{2}{|c|}{ M - F Youth } \\
\hline & $\begin{array}{c}\mathbf{E}-\mathbf{C} \\
\text { (i) }\end{array}$ & $\begin{array}{c}\mathbf{S}-\mathbf{C} \\
\text { (ii) }\end{array}$ & $\begin{array}{c}\mathbf{E}-\mathbf{C} \\
\text { (iii) } \\
\end{array}$ & $\begin{array}{c}\mathbf{S}-\mathbf{C} \\
\text { (iv) }\end{array}$ & $\begin{array}{c}\mathbf{E}-\mathbf{C} \\
(\mathbf{v}) \\
\end{array}$ & $\begin{array}{c}\mathbf{S}-\mathbf{C} \\
\text { (vi) }\end{array}$ & $\begin{array}{c}\mathbf{E}-\mathbf{C} \\
\text { (vii) }\end{array}$ & $\begin{array}{c}\mathbf{S}-\mathbf{C} \\
\text { (viii) } \\
\end{array}$ & $\begin{array}{c}\mathbf{E}-\mathbf{C} \\
(\mathbf{i x}) \\
\end{array}$ & $\begin{array}{c}\mathbf{S}-\mathbf{C} \\
(\mathbf{x}) \\
\end{array}$ \\
\hline Index for all outcomes & $\begin{array}{r}0.037 \\
(0.040)\end{array}$ & $\begin{array}{r}-0.010 \\
(0.059)\end{array}$ & $\begin{array}{r}0.034 \\
(0.046)\end{array}$ & $\begin{array}{r}-0.019 \\
(0.050)\end{array}$ & $\begin{array}{r}0.079 \\
(0.062)\end{array}$ & $\begin{array}{r}0.077 \\
(0.065)\end{array}$ & $\begin{array}{r}-0.016 \\
(0.062)\end{array}$ & $\begin{array}{l}-0.116 * \\
(0.069)\end{array}$ & $\begin{array}{r}-0.096 \\
(0.084)\end{array}$ & $\begin{array}{l}-0.193 * * \\
(0.089)\end{array}$ \\
\hline $\begin{array}{l}\text { Economic } \\
\text { self-sufficiency }\end{array}$ & $\begin{array}{r}-0.029 \\
(0.040)\end{array}$ & $\begin{array}{l}-0.112 * \\
(0.059)\end{array}$ & & & & & & & & \\
\hline $\begin{array}{c}\text { Absence of physical } \\
\text { health problems }\end{array}$ & $\begin{array}{r}0.055 \\
(0.042)\end{array}$ & $\begin{array}{r}0.062 \\
(0.058)\end{array}$ & $\begin{array}{r}0.025 \\
(0.047)\end{array}$ & $\begin{array}{r}0.025 \\
(0.052)\end{array}$ & $\begin{array}{l}0.109 * \\
(0.061)\end{array}$ & $\begin{array}{l}0.124 * \\
(0.065)\end{array}$ & $\begin{array}{r}-0.075 \\
(0.068)\end{array}$ & $\begin{array}{r}-0.058 \\
(0.078)\end{array}$ & $\begin{array}{l}-0.184 * * \\
(0.088)\end{array}$ & $\begin{array}{l}-0.182 * \\
(0.100)\end{array}$ \\
\hline $\begin{array}{l}\text { Absence of mental } \\
\text { health problems }\end{array}$ & $\begin{array}{r}0.069 \\
(0.042)\end{array}$ & $\begin{array}{r}0.063 \\
(0.062)\end{array}$ & $\begin{array}{r}0.089 * * \\
(0.044)\end{array}$ & $\begin{array}{r}-0.006 \\
(0.049)\end{array}$ & $\begin{array}{l}0.160 * * * \\
(0.058)\end{array}$ & $\begin{array}{r}0.039 \\
(0.065)\end{array}$ & $\begin{array}{r}0.008 \\
(0.064)\end{array}$ & $\begin{array}{r}-0.062 \\
(0.071)\end{array}$ & $\begin{array}{l}-0.151 * \\
(0.085)\end{array}$ & $\begin{array}{l}-0.101 \\
(0.095)\end{array}$ \\
\hline $\begin{array}{l}\text { Absence of risky } \\
\text { behavior }\end{array}$ & & & $\begin{array}{r}0.009 \\
(0.047)\end{array}$ & $\begin{array}{r}-0.035 \\
(0.049)\end{array}$ & $\begin{array}{r}-0.001 \\
(0.065)\end{array}$ & $\begin{array}{r}0.007 \\
(0.066)\end{array}$ & $\begin{array}{r}0.027 \\
(0.061)\end{array}$ & $\begin{array}{r}-0.069 \\
(0.067)\end{array}$ & $\begin{array}{r}0.028 \\
(0.085)\end{array}$ & $\begin{array}{r}-0.076 \\
(0.090)\end{array}$ \\
\hline Education & & & $\begin{array}{r}-0.024 \\
(0.045)\end{array}$ & $\begin{array}{r}-0.021 \\
(0.053)\end{array}$ & $\begin{array}{r}-0.043 \\
(0.061)\end{array}$ & $\begin{array}{r}0.027 \\
(0.072)\end{array}$ & $\begin{array}{r}-0.006 \\
(0.061)\end{array}$ & $\begin{array}{r}-0.082 \\
(0.069)\end{array}$ & $\begin{array}{r}0.037 \\
(0.082)\end{array}$ & $\begin{array}{l}-0.109 \\
(0.094)\end{array}$ \\
\hline
\end{tabular}

Notes : E - C denotes Experimental vs. control; $\mathrm{S}-\mathrm{C}$ denotes Section 8 vs. control. Estimates are the intent-to-treat effect sizes from an ordinary least squares regression of each outcome on treatment indicators and the baseline covariates listed in Appendix Tables 1 and 1B. In columns (v)-(x), gender is interacted with the treatment indicators and baseline covariates described above. $\mathrm{M}-\mathrm{F}$ Youth is male - female difference. Robust standard errors (adjusted for household clustering in the youth analysis) are in parentheses. Index components are as follows (positive outcomes (+) were included as is, while the signs for negative outcomes $(-)$ were reversed so that higher index values indicate "better" outcomes): Adult economic self-sufficiency: + adult employed and not on TANF + employed + 2009 earnings - on TANF - 2009 government income. Adult mental health: - distress index - depression - Generalized Anxiety Disorder + calmness + sleep. Adult physical health: - self-reported health fair/poor - asthma attack past year - obesity - hypertension - trouble carrying/climbing. Youth physical health: - self-reported health fair/poor - asthma attack past year - overweight - nonsports injury past year. Youth mental health: - distress index depression - Generalized Anxiety Disorder. Youth risky behavior: - marijuana past 30 days - smoking past 30 days - alcohol past 30 days - ever pregnant or gotten someone pregnant. Youth education: + graduated high school or still in school + in school or working + Early Childhood Longitudinal StudyKindergarten cohort study (ECLS-K) reading score + ECLS-K math score. For adults, the index for all outcomes includes the 15 measures in the selfsufficiency, physical health, and mental health indices. For youth, the index for all outcomes includes the 15 measures in the physical health, mental health, risky behavior, and education indices.

Source and Sample: The sample is all adults and youth aged 15-20 (as of December 2007) who were interviewed as part of the long-term survey. Sample sizes in the E, S, and C groups are 1,456, 678, and 1,139 for adults and 1,437, 1,031, 1,153 for youth. *** Significant at the 1 percent level.

** Significant at the 5 percent level.

* Significant at the 10 percent level. 
APPENDIX TABLE 4 - EFFECTS ON ADULT ECONOMIC SELF-SUFFICIENCY

\begin{tabular}{|c|c|c|c|c|c|c|c|c|c|}
\hline & \multirow[b]{2}{*}{$\mathbf{C M}$} & \multicolumn{4}{|c|}{ Experimental vs. Control } & \multicolumn{4}{|c|}{ Section 8 vs. Control } \\
\hline & & ITT & TOT & $\mathbf{C C M}$ & $\mathbf{N}$ & ITT & TOT & $\mathbf{C C M}$ & $\mathbf{N}$ \\
\hline \multicolumn{10}{|l|}{ A. Survey data } \\
\hline Employed and not receiving TANF & 0.499 & $\begin{array}{r}-0.020 \\
(0.021)\end{array}$ & $\begin{array}{r}-0.041 \\
(0.043)\end{array}$ & 0.560 & 2585 & $\begin{array}{l}-0.066 \text { ** } \\
(0.030)\end{array}$ & $\begin{array}{l}-0.106 * * \\
(0.048)\end{array}$ & 0.577 & 1809 \\
\hline Employed & 0.525 & $\begin{array}{r}-0.007 \\
(0.021)\end{array}$ & $\begin{array}{r}-0.014 \\
(0.043)\end{array}$ & 0.576 & 2586 & $\begin{array}{l}-0.068 * * \\
(0.030)\end{array}$ & $\begin{array}{l}-0.108 * * \\
(0.048)\end{array}$ & 0.606 & 1813 \\
\hline Earnings & $\$ 12,289$ & $\begin{array}{r}293 \\
(576)\end{array}$ & $\begin{array}{r}613 \\
(1208)\end{array}$ & $\$ 12,625$ & 2493 & $\begin{array}{r}-251 \\
(883)\end{array}$ & $\begin{array}{r}-399 \\
(1403)\end{array}$ & $\$ 12,717$ & 1736 \\
\hline Receiving TANF & 0.158 & $\begin{array}{r}0.011 \\
(0.015)\end{array}$ & $\begin{array}{r}0.022 \\
(0.031)\end{array}$ & 0.147 & 2590 & $\begin{array}{c}0.037 * \\
(0.022)\end{array}$ & $\begin{array}{c}0.059 * \\
(0.035)\end{array}$ & 0.102 & 1806 \\
\hline Government income & $\$ 3,543$ & $\begin{array}{r}255 \\
(217)\end{array}$ & $\begin{array}{r}530 \\
(451)\end{array}$ & $\$ 2,902$ & 2493 & $\begin{array}{r}191 \\
(318)\end{array}$ & $\begin{array}{r}300 \\
(500)\end{array}$ & $\$ 3,169$ & 1737 \\
\hline \multicolumn{10}{|l|}{ B. Administrative data } \\
\hline Employed & 0.465 & $\begin{array}{r}-0.004 \\
(0.017)\end{array}$ & $\begin{array}{r}-0.009 \\
(0.036)\end{array}$ & 0.495 & 2980 & $\begin{array}{r}0.000 \\
(0.019)\end{array}$ & $\begin{array}{r}0.000 \\
(0.030)\end{array}$ & 0.482 & 2526 \\
\hline Earnings & $\$ 11,325$ & $\begin{array}{r}-348 \\
(524)\end{array}$ & $\begin{array}{r}-732 \\
(1102)\end{array}$ & $\$ 12,441$ & 2980 & $\begin{array}{r}113 \\
(581)\end{array}$ & $\begin{array}{r}181 \\
(982)\end{array}$ & $\$ 11,542$ & 2526 \\
\hline
\end{tabular}

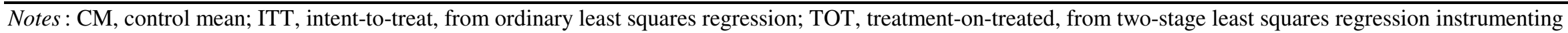

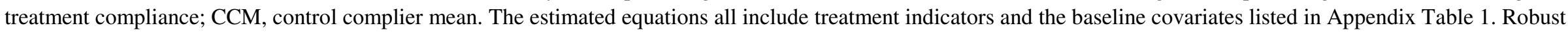
standard errors are in parentheses. Rows shown in the table are the components of the economic self-sufficiency index described in the notes to Table 1 . TANF denotes Temporary Assistance for Needy Families. The administrative data effects were calculated using a slightly different estimation approach, pooling all three groups and including indicators for both treatments (whereas the survey data effects were estimated via separate regressions for the two treatments). Differences between estimation approaches are minimal.

Source and Sample: The survey data sample is all adults interviewed as part of the long-term survey (N=3,273). The administrative data sample is adults from all MTO households for whom consent to administrative data collection was available $(\mathrm{N}=4,194)$.

** Significant at the 5 percent level.

* Significant at the 10 percent level. 


\begin{tabular}{|c|c|c|c|c|c|c|c|c|c|c|}
\hline & \multirow[b]{2}{*}{$\mathbf{C M}$} & \multicolumn{5}{|c|}{ Experimental vs. Control } & \multicolumn{4}{|c|}{ Section 8 vs. Control } \\
\hline & & ITT & & TOT & CCM & $\mathbf{N}$ & ITT & TOT & $\mathbf{C C M}$ & $\mathbf{N}$ \\
\hline \multicolumn{11}{|l|}{ A. Mental health } \\
\hline Psychological distress, K6 z-score & 0.000 & $\begin{array}{r}-0.106 \\
(0.042)\end{array}$ & $* *$ & $\begin{array}{l}-0.219 * * \\
(0.087)\end{array}$ & 0.058 & 2595 & $\begin{array}{r}-0.081 \\
(0.060)\end{array}$ & $\begin{array}{r}-0.130 \\
(0.096)\end{array}$ & -0.014 & 1817 \\
\hline Calm and peaceful & 0.487 & $\begin{array}{r}0.015 \\
(0.022)\end{array}$ & & $\begin{array}{r}0.032 \\
(0.045)\end{array}$ & 0.502 & 2594 & $\begin{array}{r}-0.039 \\
(0.031)\end{array}$ & $\begin{array}{r}-0.063 \\
(0.050)\end{array}$ & 0.552 & 1816 \\
\hline \multicolumn{11}{|l|}{ B. Physical health } \\
\hline Fair or poor self-rated health & 0.436 & $\begin{array}{r}-0.004 \\
(0.020)\end{array}$ & & $\begin{array}{r}-0.007 \\
(0.042)\end{array}$ & 0.433 & 2591 & $\begin{array}{r}0.017 \\
(0.030)\end{array}$ & $\begin{array}{r}0.028 \\
(0.048)\end{array}$ & 0.369 & 1814 \\
\hline Slept 7-8 hours last night & 0.291 & $\begin{array}{r}0.014 \\
(0.020)\end{array}$ & & $\begin{array}{r}0.029 \\
(0.042)\end{array}$ & 0.285 & 2569 & $\begin{array}{r}0.015 \\
(0.029)\end{array}$ & $\begin{array}{r}0.024 \\
(0.047)\end{array}$ & 0.291 & 1800 \\
\hline Has trouble climbing stairs or carrying groceries & 0.510 & $\begin{array}{r}-0.050 \\
(0.021)\end{array}$ & $* *$ & $\begin{array}{l}-0.104^{* *} \\
(0.043)\end{array}$ & 0.514 & 2592 & $\begin{array}{r}-0.026 \\
(0.030)\end{array}$ & $\begin{array}{r}-0.041 \\
(0.048)\end{array}$ & 0.476 & 1815 \\
\hline Asthma attack in past year & 0.293 & $\begin{array}{r}-0.017 \\
(0.019)\end{array}$ & & $\begin{array}{r}-0.036 \\
(0.040)\end{array}$ & 0.285 & 2593 & $\begin{array}{r}-0.037 \\
(0.028)\end{array}$ & $\begin{array}{r}-0.058 \\
(0.044)\end{array}$ & 0.303 & 1811 \\
\hline Hypertension & 0.315 & $\begin{array}{r}0.007 \\
(0.020)\end{array}$ & & $\begin{array}{r}0.015 \\
(0.042)\end{array}$ & 0.268 & 2462 & $\begin{array}{r}-0.023 \\
(0.029)\end{array}$ & $\begin{array}{r}-0.036 \\
(0.045)\end{array}$ & 0.304 & 1719 \\
\hline $\mathrm{BMI} \geq 30$ & 0.584 & $\begin{array}{r}-0.011 \\
(0.021)\end{array}$ & & $\begin{array}{r}-0.023 \\
(0.045)\end{array}$ & 0.589 & 2550 & $\begin{array}{r}-0.010 \\
(0.031)\end{array}$ & $\begin{array}{r}-0.017 \\
(0.050)\end{array}$ & 0.581 & 1788 \\
\hline $\mathrm{BMI} \geq 35$ & 0.351 & $\begin{array}{r}-0.044 \\
(0.020)\end{array}$ & $* *$ & $\begin{array}{l}-0.092 * * \\
(0.042)\end{array}$ & 0.404 & 2550 & $\begin{array}{l}-0.061 * * \\
(0.029)\end{array}$ & $\begin{array}{l}-0.098 * * \\
(0.047)\end{array}$ & 0.389 & 1788 \\
\hline $\mathrm{BMI} \geq 40$ & 0.175 & $\begin{array}{r}-0.036 \\
(0.016)\end{array}$ & $* *$ & $\begin{array}{l}-0.074 * * \\
(0.032)\end{array}$ & 0.213 & 2550 & $\begin{array}{l}-0.038 * \\
(0.023)\end{array}$ & $\begin{array}{l}-0.060 * \\
(0.037)\end{array}$ & 0.215 & 1788 \\
\hline Blood test detected diabetes $(\mathrm{HbA} 1 \mathrm{c} \geq 6.5 \%)$ & 0.204 & $\begin{array}{r}-0.050 \\
(0.018)\end{array}$ & $* * *$ & $\begin{array}{l}-0.103 * * * \\
(0.038)\end{array}$ & 0.255 & 2130 & $\begin{array}{r}-0.015 \\
(0.026)\end{array}$ & $\begin{array}{r}-0.023 \\
(0.041)\end{array}$ & 0.229 & 1554 \\
\hline
\end{tabular}

Notes : CM, control mean; ITT, intent-to-treat, from ordinary least squares regression; TOT, treatment-on-treated, from two-stage least squares regression instrumenting treatment compliance; CCM, control complier mean. The estimated equations all include treatment indicators and the baseline covariates listed in Appendix Table 1.

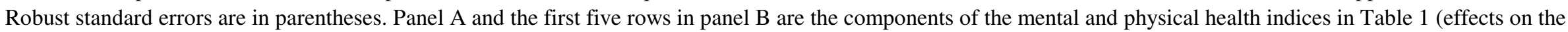
depression and Generalized Anxiety Disorder components of the mental health index are withheld). The effects on body mass index (BMI) and diabetes represent key

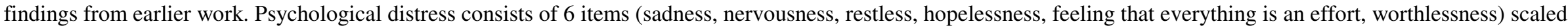

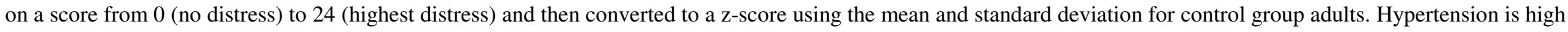

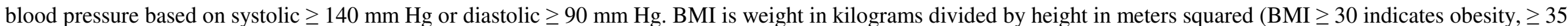
indicates severe obesity, $\geq 40$ indicates extreme obesity). Glycosylated hemoglobin (HbA1c) level is from a blood sample, and a level $\geq 6.5 \%$ indicates diabetes.

Source and Sample: The sample is all adults interviewed as part of the long-term survey $(\mathrm{N}=3,273)$.

*** Significant at the 1 percent level.

** Significant at the 5 percent level.

* Significant at the 10 percent level. 
APPENDIX TABLE 6 - INTENT-TO-TREAT EFFECTS ON ADULT ECONOMIC SELF-SUFFICIENCY AND HEALTH BY AGE AT BASELINE

\begin{tabular}{|c|c|c|c|c|c|c|c|c|c|}
\hline & \multicolumn{4}{|c|}{ Under Age 33 at Baseline } & \multicolumn{3}{|c|}{ Age 33 and Over at Baseline } & \multicolumn{2}{|c|}{ Difference by Age } \\
\hline & $\mathbf{C M}$ & $\mathbf{E}-\mathbf{C}$ & & $\mathbf{S}-\mathbf{C}$ & $\mathbf{C M}$ & $\mathbf{E}-\mathbf{C}$ & $\mathbf{S}-\mathbf{C}$ & $\mathbf{E}-\mathbf{C}$ & $\mathbf{S}-\mathbf{C}$ \\
\hline \multicolumn{10}{|l|}{ A. Economic self-sufficiency } \\
\hline Employed and not on TANF & 0.564 & $\begin{array}{r}-0.032 \\
(0.029)\end{array}$ & & $\begin{array}{l}-0.066 * \\
(0.040)\end{array}$ & 0.421 & $\begin{array}{r}-0.005 \\
(0.029)\end{array}$ & $\begin{array}{l}-0.068 * \\
(0.040)\end{array}$ & $\begin{array}{r}0.027 \\
(0.041)\end{array}$ & $\begin{array}{r}-0.002 \\
(0.052)\end{array}$ \\
\hline Employed & 0.599 & $\begin{array}{r}-0.017 \\
(0.028)\end{array}$ & & $\begin{array}{l}-0.070 * \\
(0.040)\end{array}$ & 0.439 & $\begin{array}{r}0.005 \\
(0.029)\end{array}$ & $\begin{array}{l}-0.066 * \\
(0.040)\end{array}$ & $\begin{array}{r}0.023 \\
(0.040)\end{array}$ & $\begin{array}{r}0.004 \\
(0.052)\end{array}$ \\
\hline Earnings in 2009 & $\$ 14,232$ & $\begin{array}{r}815 \\
(839)\end{array}$ & & $\begin{array}{r}-572 \\
(1198)\end{array}$ & $\$ 10,037$ & $\begin{array}{r}-312 \\
(772)\end{array}$ & $\begin{array}{r}49 \\
(1117)\end{array}$ & $\begin{array}{r}-1126 \\
(1138)\end{array}$ & $\begin{array}{r}621 \\
(1501)\end{array}$ \\
\hline On TANF & 0.187 & $\begin{array}{r}0.003 \\
(0.022)\end{array}$ & & $\begin{array}{r}0.022 \\
(0.030)\end{array}$ & 0.122 & $\begin{array}{r}0.020 \\
(0.021)\end{array}$ & $\begin{array}{r}0.053 * \\
(0.028)\end{array}$ & $\begin{array}{r}0.017 \\
(0.030)\end{array}$ & $\begin{array}{r}0.031 \\
(0.038)\end{array}$ \\
\hline Government income in 2009 & $\$ 3,066$ & $\begin{array}{r}274 \\
(293)\end{array}$ & & $\begin{array}{r}-308 \\
(385)\end{array}$ & $\$ 4,112$ & $\begin{array}{r}232 \\
(318)\end{array}$ & $\begin{array}{r}763 \\
(476)\end{array}$ & $\begin{array}{r}-42 \\
(430)\end{array}$ & $\begin{array}{l}1071 * \\
(579)\end{array}$ \\
\hline \multicolumn{10}{|l|}{ B. Mental health } \\
\hline Psychological distress, K6 z-score & -0.031 & $\begin{array}{r}-0.162 \\
(0.054)\end{array}$ & $* * *$ & $\begin{array}{l}-0.150 * * \\
(0.075)\end{array}$ & 0.037 & $\begin{array}{r}-0.040 \\
(0.065)\end{array}$ & $\begin{array}{r}0.000 \\
(0.084)\end{array}$ & $\begin{array}{r}0.122 \\
(0.085)\end{array}$ & $\begin{array}{r}0.149 \\
(0.104)\end{array}$ \\
\hline Calm and peaceful & 0.480 & $\begin{array}{r}0.019 \\
(0.029)\end{array}$ & & $\begin{array}{r}-0.008 \\
(0.040)\end{array}$ & 0.495 & $\begin{array}{r}0.010 \\
(0.032)\end{array}$ & $\begin{array}{l}-0.075 * \\
(0.042)\end{array}$ & $\begin{array}{r}-0.009 \\
(0.043)\end{array}$ & $\begin{array}{r}-0.067 \\
(0.054)\end{array}$ \\
\hline \multicolumn{10}{|l|}{ C. Physical health } \\
\hline Fair or poor self-rated health & 0.357 & $\begin{array}{r}-0.015 \\
(0.027)\end{array}$ & & $\begin{array}{r}-0.009 \\
(0.038)\end{array}$ & 0.529 & $\begin{array}{r}0.009 \\
(0.030)\end{array}$ & $\begin{array}{r}0.046 \\
(0.041)\end{array}$ & $\begin{array}{r}0.024 \\
(0.041)\end{array}$ & $\begin{array}{r}0.055 \\
(0.051)\end{array}$ \\
\hline Slept 7-8 hours per night & 0.277 & $\begin{array}{r}0.013 \\
(0.027)\end{array}$ & & $\begin{array}{r}0.015 \\
(0.037)\end{array}$ & 0.309 & $\begin{array}{r}0.016 \\
(0.030)\end{array}$ & $\begin{array}{r}0.016 \\
(0.040)\end{array}$ & $\begin{array}{r}0.003 \\
(0.040)\end{array}$ & $\begin{array}{r}0.001 \\
(0.049)\end{array}$ \\
\hline Has trouble climbing stairs or carrying groceries & 0.415 & $\begin{array}{r}-0.074 \\
(0.028)\end{array}$ & $* * *$ & $\begin{array}{r}-0.042 \\
(0.039)\end{array}$ & 0.624 & $\begin{array}{r}-0.023 \\
(0.030)\end{array}$ & $\begin{array}{r}-0.005 \\
(0.040)\end{array}$ & $\begin{array}{r}0.051 \\
(0.041)\end{array}$ & $\begin{array}{r}0.037 \\
(0.051)\end{array}$ \\
\hline Asthma attack in past year & 0.294 & $\begin{array}{r}-0.056 \\
(0.026)\end{array}$ & $* *$ & $\begin{array}{l}-0.081 * * \\
(0.036)\end{array}$ & 0.293 & $\begin{array}{r}0.027 \\
(0.029)\end{array}$ & $\begin{array}{r}0.013 \\
(0.038)\end{array}$ & $\begin{array}{l}0.083 * * \\
(0.039)\end{array}$ & $\begin{array}{l}0.094 \text { ** } \\
(0.047)\end{array}$ \\
\hline Has hypertension & 0.253 & $\begin{array}{c}-0.002 \\
(0.026)\end{array}$ & & $\begin{array}{l}-0.051 \\
(0.034)\end{array}$ & 0.389 & $\begin{array}{r}0.017 \\
(0.032)\end{array}$ & $\begin{array}{r}0.012 \\
(0.042)\end{array}$ & $\begin{array}{r}0.019 \\
(0.041)\end{array}$ & $\begin{array}{r}0.063 \\
(0.050)\end{array}$ \\
\hline
\end{tabular}




\begin{tabular}{|c|c|c|c|c|c|c|c|c|}
\hline & \multicolumn{3}{|c|}{ Under Age 33 at Baseline } & \multicolumn{3}{|c|}{ Age 33 and Over at Baseline } & \multicolumn{2}{|c|}{ Difference by Age } \\
\hline & $\mathbf{C M}$ & $\mathbf{E}-\mathbf{C}$ & $\mathbf{S}-\mathbf{C}$ & $\mathbf{C M}$ & $\mathbf{E}-\mathbf{C}$ & $\mathbf{S}-\mathbf{C}$ & $\mathbf{E}-\mathbf{C}$ & $\mathbf{S}-\mathbf{C}$ \\
\hline \multicolumn{9}{|l|}{ C. Physical health (continued) } \\
\hline \multirow{2}{*}{$\mathrm{BMI} \geq 30$} & 0.576 & 0.022 & -0.020 & 0.594 & -0.050 & 0.000 & $-0.072 *$ & 0.021 \\
\hline & & $(0.029)$ & $(0.041)$ & & $(0.032)$ & $(0.041)$ & $(0.043)$ & $(0.053)$ \\
\hline \multirow[t]{2}{*}{$\mathrm{BMI} \geq 35$} & 0.381 & $-0.063 * *$ & $-0.099 * * *$ & 0.315 & -0.023 & -0.021 & 0.040 & 0.079 \\
\hline & & $(0.028)$ & $(0.038)$ & & $(0.029)$ & $(0.039)$ & $(0.040)$ & $(0.050)$ \\
\hline \multirow[t]{2}{*}{$\mathrm{BMI} \geq 40$} & 0.194 & $-0.039 *$ & $-0.062 * *$ & 0.153 & -0.033 & -0.010 & 0.006 & 0.052 \\
\hline & & $(0.022)$ & $(0.030)$ & & $(0.022)$ & $(0.031)$ & $(0.031)$ & $(0.039)$ \\
\hline \multirow[t]{2}{*}{ Blood test detected diabetes $(\mathrm{HbA} 1 \mathrm{c} \geq 6.5 \%)$} & 0.132 & $-0.047 * *$ & -0.023 & 0.294 & $-0.053 *$ & -0.006 & -0.006 & 0.017 \\
\hline & & $(0.021)$ & $(0.030)$ & & $(0.031)$ & $(0.040)$ & $(0.037)$ & $(0.046)$ \\
\hline
\end{tabular}

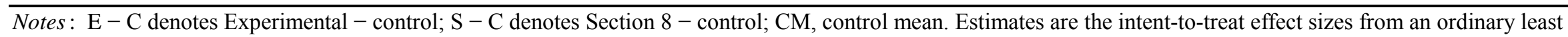

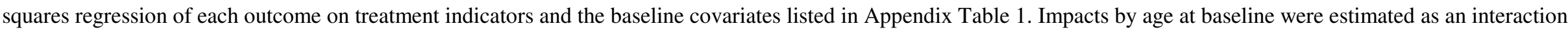

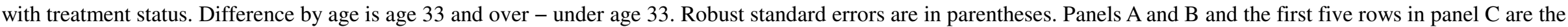

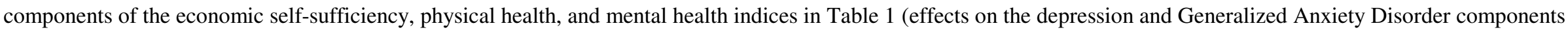

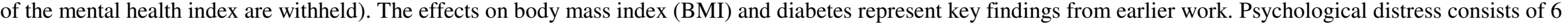

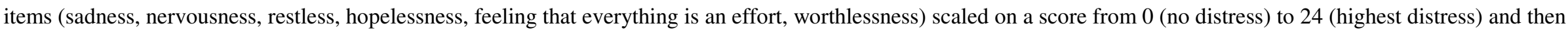

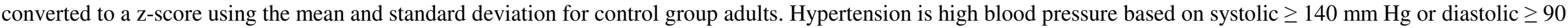
$\mathrm{mm} \mathrm{Hg}$. BMI is weight in kilograms divided by height in meters squared (BMI $\geq 30$ indicates obesity, $\geq 35$ indicates severe obesity, $\geq 40$ indicates extreme obesity).

Glycosylated hemoglobin (HbA1c) level is from a blood sample, and a level $\geq 6.5 \%$ indicates diabetes. Source and Sample: The sample is all adults interviewed as part of the long-term survey $(\mathrm{N}=3,273)$.

*** Significant at the 1 percent level.

** Significant at the 5 percent level.

* Significant at the 10 percent level. 
APPENDIX TABLE 7 - EFFECTS ON ADULT SUBJECTIVE WELL-BEING

\begin{tabular}{|c|c|c|c|c|c|c|c|c|c|c|}
\hline & \multirow[b]{2}{*}{$\mathbf{C M}$} & \multicolumn{5}{|c|}{ Experimental vs. Control } & \multicolumn{4}{|c|}{ Section 8 vs. Control } \\
\hline & & ITT & & TOT & CCM & $\mathbf{N}$ & ITT & TOT & $\mathbf{C C M}$ & $\mathbf{N}$ \\
\hline $\begin{array}{l}\text { Very happy } \\
\text { (vs. pretty happy or not very happy) }\end{array}$ & 0.228 & $\begin{array}{r}0.010 \\
(0.018)\end{array}$ & & $\begin{array}{r}0.022 \\
(0.037)\end{array}$ & 0.242 & 2593 & $\begin{array}{l}0.050 * \\
(0.027)\end{array}$ & $\begin{array}{l}0.079 * \\
(0.043)\end{array}$ & 0.192 & 1811 \\
\hline $\begin{array}{l}\text { Very happy or pretty happy } \\
\text { (vs. not very happy) }\end{array}$ & 0.725 & $\begin{array}{r}0.045 \\
(0.018)\end{array}$ & $* *$ & $\begin{array}{l}0.094 * * \\
(0.038)\end{array}$ & 0.712 & 2593 & $\begin{array}{r}0.034 \\
(0.027)\end{array}$ & $\begin{array}{r}0.054 \\
(0.042)\end{array}$ & 0.730 & 1811 \\
\hline Happiness 3-point scale & 1.953 & $\begin{array}{r}0.056 \\
(0.029)\end{array}$ & $*$ & $\begin{array}{l}0.116 * \\
(0.061)\end{array}$ & 1.954 & 2593 & $\begin{array}{l}0.084 * \\
(0.043)\end{array}$ & $\begin{array}{l}0.133 * \\
(0.069)\end{array}$ & 1.922 & 1811 \\
\hline Happiness 3-point scale, z-score & 0.000 & $\begin{array}{r}0.079 \\
(0.042)\end{array}$ & $*$ & $\begin{array}{l}0.163 * \\
(0.086)\end{array}$ & 0.001 & 2593 & $\begin{array}{l}0.119 * \\
(0.061)\end{array}$ & $\begin{array}{l}0.187 * \\
(0.097)\end{array}$ & -0.045 & 1811 \\
\hline
\end{tabular}

Notes : CM, control mean; ITT, intent-to-treat, from ordinary least squares regression; TOT, treatment-on-treated, from two-stage least squares regression instrumenting

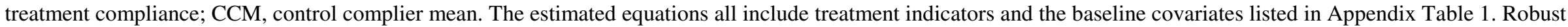
standard errors are in parentheses. Subjective well-being is from a 3-point happiness scale (1=not too happy, 2=pretty happy, 3=very happy), and the z-score was standardized using the control group mean and standard deviation.

Source and Sample: The sample is all adults interviewed as part of the long-term survey $(\mathrm{N}=3,273)$.

** Significant at the 5 percent level.

* Significant at the 10 percent level. 


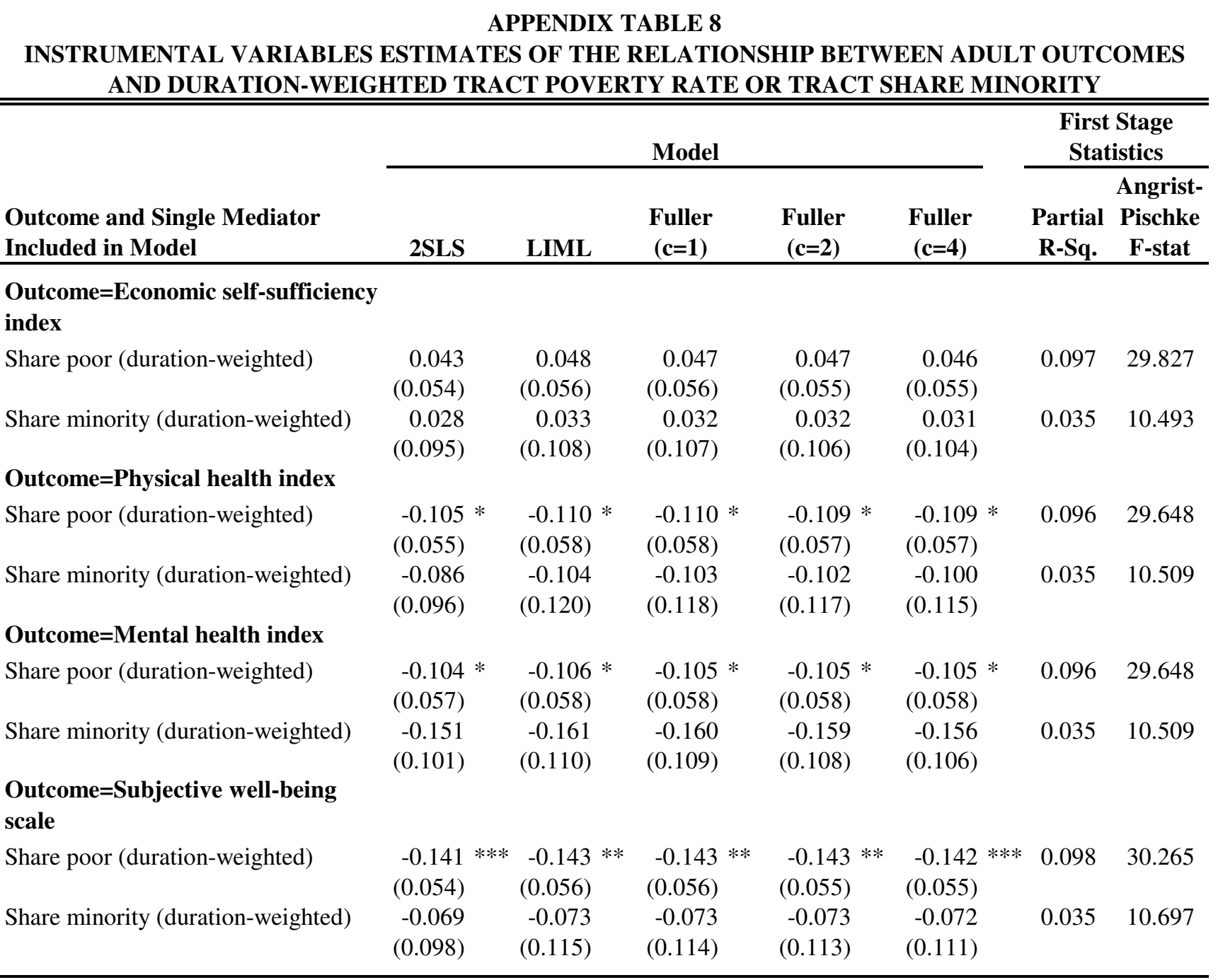

Notes: Coefficient estimates for the various instrumental variable regressions shown use site and treatment group interactions as instruments. Each regression also controlled for the baseline covariates presented in Appendix Table 1 and for field release and was weighted. Columns labels are as follows: 2SLS columns report results for two-stage least squares, LIML is an unmodified limited information maximum likelihood (LIML) model, and columns labeled Fuller present Fuller-modified LIML models with constants 1, 2 and 4, respectively. Robust standard errors are in parentheses. All measures were converted to z-scores using the control group mean and standard deviation. See the notes to Table 1 for a description of the indices. Subjective well-being (SWB) scale refers to the 3-point happiness scale (1=not too happy, $2=$ pretty happy, $3=$ very happy). Share poor is the fraction of census tract residents living below the poverty threshold, and share minority is the fraction of census tract residents who are members of racial or ethnic minority groups. Both share poor and share minority are average measures weighted by the amount of time respondents lived at each of their addresses between random assignment and May 31, 2008 (just prior to the start of the long-term survey fielding period).

Source and Sample: SWB and the index components were self-reported or measured on the MTO long-term survey. Share poor and share minority come from interpolated data from the 1990 and 2000 decennial census as well as the 200509 American Community Survey. The sample is all adults interviewed as part of the long-term survey $(\mathrm{N}=3,273)$.

*** Significant at the 1 percent level.

** Significant at the 5 percent level.

* Significant at the 10 percent level. 
APPENDIX TABLE 9

INSTRUMENTAL VARIABLES ESTIMATES OF THE RELATIONSHIP BETWEEN ADULT OUTCOMES AND

DURATION-WEIGHTED TRACT POVERTY RATE AND TRACT SHARE MINORITY IN ONE MODEL

\begin{tabular}{|c|c|c|c|c|c|c|c|c|}
\hline \multirow[b]{2}{*}{$\begin{array}{l}\text { Outcome and Both Mediators } \\
\text { Included in Model }\end{array}$} & \multicolumn{5}{|c|}{ Model } & \multicolumn{3}{|c|}{ First Stage Statistics } \\
\hline & 2SLS & LIML & $\begin{array}{c}\text { Fuller } \\
(\mathbf{c}=1)\end{array}$ & $\begin{array}{c}\text { Fuller } \\
(\mathbf{c}=2)\end{array}$ & $\begin{array}{c}\text { Fuller } \\
(c=4)\end{array}$ & $\begin{array}{l}\text { Partial } \\
\text { R-Sq. }\end{array}$ & $\begin{array}{c}\text { Angrist- } \\
\text { Pischke } \\
\text { F-stat } \\
\end{array}$ & $\begin{array}{l}\text { Cragg- } \\
\text { Donald } \\
\text { F-stat }\end{array}$ \\
\hline \multicolumn{9}{|l|}{$\begin{array}{l}\text { Outcome=Economic self- } \\
\text { sufficiency index }\end{array}$} \\
\hline $\begin{array}{l}\text { Share poor, controlling for share } \\
\text { minority (duration-weighted) }\end{array}$ & $\begin{array}{r}0.073 \\
(0.087)\end{array}$ & $\begin{array}{r}0.088 \\
(0.103)\end{array}$ & $\begin{array}{r}0.086 \\
(0.101)\end{array}$ & $\begin{array}{r}0.085 \\
(0.100)\end{array}$ & $\begin{array}{r}0.082 \\
(0.097)\end{array}$ & 0.052 & 14.126 & 6.132 \\
\hline $\begin{array}{l}\text { Share minority, controlling for } \\
\text { share poor (duration-weighted) }\end{array}$ & $\begin{array}{l}-0.068 \\
(0.155)\end{array}$ & $\begin{array}{r}-0.093 \\
(0.196)\end{array}$ & $\begin{array}{r}-0.091 \\
(0.192)\end{array}$ & $\begin{array}{r}-0.088 \\
(0.188)\end{array}$ & $\begin{array}{r}-0.084 \\
(0.181)\end{array}$ & 0.019 & 4.484 & \\
\hline $\begin{array}{l}\text { P-value of test that coefficients } \\
\text { are equal }\end{array}$ & 0.539 & 0.530 & 0.530 & 0.531 & 0.532 & & & \\
\hline \multicolumn{9}{|l|}{ Outcome=Physical health index } \\
\hline $\begin{array}{l}\text { Share poor, controlling for share } \\
\text { minority (duration-weighted) }\end{array}$ & $\begin{array}{l}-0.155 * \\
(0.089)\end{array}$ & $\begin{array}{r}-0.183 \\
(0.116)\end{array}$ & $\begin{array}{r}-0.181 \\
(0.114)\end{array}$ & $\begin{array}{r}-0.179 \\
(0.112)\end{array}$ & $\begin{array}{r}-0.175 \\
(0.108)\end{array}$ & 0.053 & 14.210 & 6.220 \\
\hline $\begin{array}{l}\text { Share minority, controlling for } \\
\text { share poor (duration-weighted) }\end{array}$ & $\begin{array}{r}0.118 \\
(0.159)\end{array}$ & $\begin{array}{r}0.170 \\
(0.230)\end{array}$ & $\begin{array}{r}0.166 \\
(0.224)\end{array}$ & $\begin{array}{r}0.162 \\
(0.219)\end{array}$ & $\begin{array}{r}0.155 \\
(0.210)\end{array}$ & 0.019 & 4.546 & \\
\hline $\begin{array}{l}\text { P-value of test that coefficients } \\
\text { are equal }\end{array}$ & 0.247 & 0.292 & 0.289 & 0.287 & 0.281 & & & \\
\hline \multicolumn{9}{|l|}{ Outcome=Mental health index } \\
\hline $\begin{array}{l}\text { Share poor, controlling for share } \\
\text { minority (duration-weighted) }\end{array}$ & $\begin{array}{r}-0.089 \\
(0.091)\end{array}$ & $\begin{array}{r}-0.090 \\
(0.100)\end{array}$ & $\begin{array}{r}-0.090 \\
(0.098)\end{array}$ & $\begin{array}{r}-0.090 \\
(0.097)\end{array}$ & $\begin{array}{r}-0.090 \\
(0.095)\end{array}$ & 0.053 & 14.210 & 6.220 \\
\hline $\begin{array}{l}\text { Share minority, controlling for } \\
\text { share poor (duration-weighted) }\end{array}$ & $\begin{array}{r}-0.034 \\
(0.160)\end{array}$ & $\begin{array}{r}-0.036 \\
(0.183)\end{array}$ & $\begin{array}{r}-0.036 \\
(0.179)\end{array}$ & $\begin{array}{r}-0.036 \\
(0.176)\end{array}$ & $\begin{array}{r}-0.035 \\
(0.170)\end{array}$ & 0.019 & 4.546 & \\
\hline $\begin{array}{l}\text { P-value of test that coefficients } \\
\text { are equal }\end{array}$ & 0.817 & 0.842 & 0.838 & 0.835 & 0.829 & & & \\
\hline \multicolumn{9}{|l|}{$\begin{array}{l}\text { Outcome=Subjective well- } \\
\text { being scale }\end{array}$} \\
\hline $\begin{array}{l}\text { Share poor, controlling for share } \\
\text { minority (duration-weighted) }\end{array}$ & $\begin{array}{l}-0.261 * * * \\
(0.093)\end{array}$ & $\begin{array}{l}-0.279 * * * \\
(0.102)\end{array}$ & $\begin{array}{l}-0.276 * * * \\
(0.100)\end{array}$ & $\begin{array}{l}-0.273 * * * \\
(0.099)\end{array}$ & $\begin{array}{l}-0.268 * * * \\
(0.096)\end{array}$ & 0.052 & 14.246 & 6.077 \\
\hline $\begin{array}{l}\text { Share minority, controlling for } \\
\text { share poor (duration-weighted) }\end{array}$ & $\begin{array}{l}0.279 * \\
(0.169)\end{array}$ & $\begin{array}{l}0.316 * \\
(0.191)\end{array}$ & $\begin{array}{l}0.310 * \\
(0.187)\end{array}$ & $\begin{array}{l}0.304 * \\
(0.184)\end{array}$ & $\begin{array}{l}0.293 * \\
(0.177)\end{array}$ & 0.019 & 4.552 & \\
\hline $\begin{array}{l}\text { P-value of test that coefficients } \\
\text { are equal }\end{array}$ & 0.030 & 0.035 & 0.034 & 0.033 & 0.032 & & & \\
\hline
\end{tabular}

Notes: Coefficient estimates for the various instrumental variable regressions shown use site and treatment group interactions as instruments. Each regression presents coefficients for the respective neighborhood measure controlling for the other mediator listed. Each regression also controlled for the baseline covariates presented in Appendix Table 1 and for field release and was weighted. Columns labels are as follows: 2SLS columns report results for two-stage least squares, LIML is an unmodified limited information maximum likelihood (LIML) model, and columns labeled Fuller present Fuller-modified LIML models with constants 1, 2 and 4, respectively. Robust standard errors shown in parentheses; * $=\mathrm{p}$-value $<0.05, \sim=\mathrm{p}$ value $<0.10$. All measures were converted to $\mathrm{z}$-scores using the control group mean and standard deviation. See the notes to Table 1 for a description of the indices. Subjective well-being (SWB) scale refers to the 3-point happiness scale (1=not too happy, $2=$ pretty happy, $3=$ very happy). Share poor is the fraction of census tract residents living below the poverty threshold, and share minority is the fraction of census tract residents who are members of racial or ethnic minority groups. Both share poor and share minority are average measures weighted by the amount of time respondents lived at each of their addresses between random assignment and May 31, 2008 (just prior to the start of the long-term survey fielding period).

Source and Sample: SWB and the index components were self-reported or measured on the MTO long-term survey. Share poor and share minority come from interpolated data from the 1990 and 2000 decennial census as well as the 2005-09

American Community Survey. The sample is all adults interviewed as part of the long-term survey $(\mathrm{N}=3,273)$.

*** Significant at the 1 percent level.

* Significant at the 10 percent level. 
APPENDIX TABLE 10 - INTENT-TO-TREAT EFFECTS ON YOUTH OUTCOMES

\begin{tabular}{|c|c|c|c|c|c|c|c|c|}
\hline & \multicolumn{3}{|c|}{ Female Youth } & \multicolumn{3}{|c|}{ Male Youth } & \multicolumn{2}{|c|}{ M - F Difference } \\
\hline & $\mathbf{C M}$ & $\mathbf{E}-\mathbf{C}$ & $\mathbf{S}-\mathbf{C}$ & $\mathbf{C M}$ & $\mathbf{E}-\mathbf{C}$ & $\mathbf{S}-\mathbf{C}$ & $\mathbf{E}-\mathbf{C}$ & $\mathbf{S}-\mathbf{C}$ \\
\hline \multicolumn{9}{|l|}{ A. Mental health } \\
\hline Psychological distress, K6 z-score & 0.000 & $\begin{array}{l}-0.143 * * \\
(0.062)\end{array}$ & $\begin{array}{r}-0.032 \\
(0.070)\end{array}$ & 0.000 & $\begin{array}{r}0.039 \\
(0.063)\end{array}$ & $\begin{array}{r}0.081 \\
(0.070)\end{array}$ & $\begin{array}{l}0.182 \text { ** } \\
(0.085)\end{array}$ & $\begin{array}{r}0.113 \\
(0.094)\end{array}$ \\
\hline \multicolumn{9}{|l|}{ B. Physical health } \\
\hline Fair or poor self-rated health & 0.149 & $\begin{array}{r}-0.014 \\
(0.022)\end{array}$ & $\begin{array}{r}-0.017 \\
(0.024)\end{array}$ & 0.110 & $\begin{array}{r}-0.003 \\
(0.020)\end{array}$ & $\begin{array}{r}-0.008 \\
(0.023)\end{array}$ & $\begin{array}{r}0.011 \\
(0.029)\end{array}$ & $\begin{array}{r}0.009 \\
(0.032)\end{array}$ \\
\hline Asthma attack in past year & 0.217 & $\begin{array}{r}-0.016 \\
(0.025)\end{array}$ & $\begin{array}{l}-0.025 \\
(0.026)\end{array}$ & 0.159 & $\begin{array}{r}0.022 \\
(0.024)\end{array}$ & $\begin{array}{r}-0.011 \\
(0.027)\end{array}$ & $\begin{array}{r}0.038 \\
(0.034)\end{array}$ & $\begin{array}{r}0.014 \\
(0.037)\end{array}$ \\
\hline Non-sports injury in past year & 0.128 & $\begin{array}{l}-0.013 \\
(0.020)\end{array}$ & $\begin{array}{l}-0.019 \\
(0.022)\end{array}$ & 0.107 & $\begin{array}{r}0.024 \\
(0.020)\end{array}$ & $\begin{array}{l}0.050 * * \\
(0.023)\end{array}$ & $\begin{array}{r}0.037 \\
(0.029)\end{array}$ & $\begin{array}{l}0.069 \text { ** } \\
(0.032)\end{array}$ \\
\hline Overweight, $\mathrm{BMI}>95$ th percentile & 0.269 & $\begin{array}{l}-0.059 * * \\
(0.028)\end{array}$ & $\begin{array}{l}-0.050 * \\
(0.030)\end{array}$ & 0.196 & $\begin{array}{r}0.015 \\
(0.025)\end{array}$ & $\begin{array}{r}0.008 \\
(0.028)\end{array}$ & $\begin{array}{l}0.074 * * \\
(0.036)\end{array}$ & $\begin{array}{r}0.058 \\
(0.039)\end{array}$ \\
\hline \multicolumn{9}{|l|}{ C. Education } \\
\hline Educationally on track & 0.827 & $\begin{array}{r}-0.004 \\
(0.023)\end{array}$ & $\begin{array}{r}0.012 \\
(0.024)\end{array}$ & 0.801 & $\begin{array}{r}-0.018 \\
(0.025)\end{array}$ & $\begin{array}{l}-0.061 * * \\
(0.029)\end{array}$ & $\begin{array}{c}-0.014 \\
(0.032)\end{array}$ & $\begin{array}{l}-0.073 * * \\
(0.036)\end{array}$ \\
\hline Currently idle (neither in school nor working) & 0.194 & $\begin{array}{r}0.030 \\
(0.024)\end{array}$ & $\begin{array}{r}0.025 \\
(0.027)\end{array}$ & 0.235 & $\begin{array}{r}-0.019 \\
(0.027)\end{array}$ & $\begin{array}{r}0.025 \\
(0.030)\end{array}$ & $\begin{array}{r}-0.049 \\
(0.035)\end{array}$ & $\begin{array}{r}0.000 \\
(0.040)\end{array}$ \\
\hline Reading assessment, z-score & 0.000 & $\begin{array}{r}-0.019 \\
(0.062)\end{array}$ & $\begin{array}{r}0.080 \\
(0.069)\end{array}$ & 0.000 & $\begin{array}{r}0.016 \\
(0.060)\end{array}$ & $\begin{array}{r}-0.033 \\
(0.066)\end{array}$ & $\begin{array}{r}0.035 \\
(0.083)\end{array}$ & $\begin{array}{r}-0.113 \\
(0.092)\end{array}$ \\
\hline Math assessment, z-score & 0.000 & $\begin{array}{r}-0.026 \\
(0.065)\end{array}$ & $\begin{array}{r}0.007 \\
(0.075)\end{array}$ & 0.000 & $\begin{array}{r}-0.057 \\
(0.061)\end{array}$ & $\begin{array}{r}0.014 \\
(0.067)\end{array}$ & $\begin{array}{r}-0.031 \\
(0.084)\end{array}$ & $\begin{array}{r}0.007 \\
(0.097)\end{array}$ \\
\hline \multicolumn{9}{|l|}{ D. Risky behavior } \\
\hline Used marijuana in past 30 days & 0.186 & $\begin{array}{r}-0.021 \\
(0.025)\end{array}$ & $\begin{array}{r}-0.019 \\
(0.028)\end{array}$ & 0.274 & $\begin{array}{r}0.003 \\
(0.030)\end{array}$ & $\begin{array}{r}0.012 \\
(0.033)\end{array}$ & $\begin{array}{r}0.024 \\
(0.038)\end{array}$ & $\begin{array}{r}0.031 \\
(0.043)\end{array}$ \\
\hline Used alcohol in past 30 days & 0.427 & $\begin{array}{r}-0.034 \\
(0.029)\end{array}$ & $\begin{array}{r}0.001 \\
(0.033)\end{array}$ & 0.474 & $\begin{array}{r}-0.044 \\
(0.031)\end{array}$ & $\begin{array}{r}0.003 \\
(0.033)\end{array}$ & $\begin{array}{r}-0.010 \\
(0.041)\end{array}$ & $\begin{array}{r}0.002 \\
(0.045)\end{array}$ \\
\hline Smoked in past 30 days & 0.163 & $\begin{array}{r}0.044 * \\
(0.024)\end{array}$ & $\begin{array}{r}0.024 \\
(0.026)\end{array}$ & 0.250 & $\begin{array}{r}0.047 * \\
(0.027)\end{array}$ & $\begin{array}{l}0.089 * * * \\
(0.031)\end{array}$ & $\begin{array}{r}0.003 \\
(0.034)\end{array}$ & $\begin{array}{l}0.066 * \\
(0.039)\end{array}$ \\
\hline Ever pregnant or gotten someone pregnant & 0.343 & $\begin{array}{r}0.002 \\
(0.028)\end{array}$ & $\begin{array}{r}-0.017 \\
(0.031)\end{array}$ & 0.273 & $\begin{array}{l}-0.047 * \\
(0.026)\end{array}$ & $\begin{array}{r}-0.025 \\
(0.031)\end{array}$ & $\begin{array}{c}-0.049 \\
(0.038)\end{array}$ & $\begin{array}{r}-0.009 \\
(0.044)\end{array}$ \\
\hline
\end{tabular}




\section{APPENDIX TABLE 10 (continued)}

Notes : E - C denotes Experimental - control; S - C denotes Section 8 - control; CM, control mean. Estimates are the intent-to-treat effect sizes from an ordinary least squares regression of each outcome on treatment indicators and the baseline covariates listed in Appendix Tables 1 and 1B. Impacts by gender were estimated as an

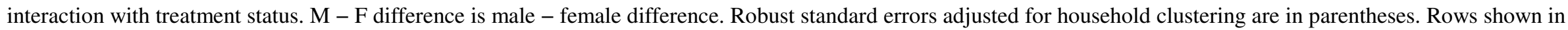
the table are the components of the mental health, physical health, education, and risky behavior indices in Table 2 (effects on the depression and Generalized Anxiety Disorder components of the mental health index are withheld). Psychological distress consists of 6 items (sadness, nervousness, restless, hopelessness, feeling that

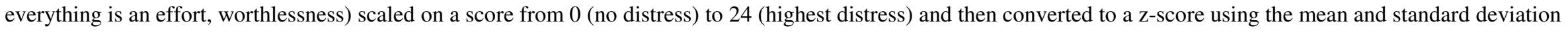
for control group youth ages 15-20 (with male and female youth standardized separately). Body mass index (BMI) values greater than the 95th percentile indicate overweight for youth. Educationally on track indicates the youth was currently in school or had received a high school diploma or certificate of General Educational

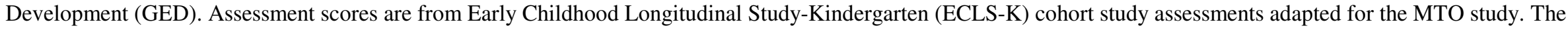

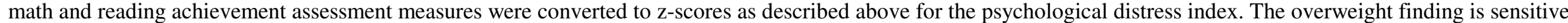

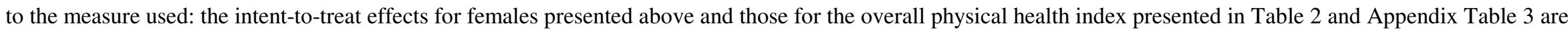
not quite statistically significant when using cutoffs from the International Obesity Task Force as presented in Sanbonmatsu et al. (2011). Source and Sample: The sample is youth ages 15-20 as of December 2007 interviewed as part of the long-term survey (N=3,621).

*** Significant at the 1 percent level.

** Significant at the 5 percent level.

* Significant at the 10 percent level. 
APPENDIX TABLE 11 - INTENT-TO-TREAT EFFECTS ON YOUTH ACHIEVEMENT ASSESSMENT SCORES,

BY GENDER AND AGE AT BASELINE

\begin{tabular}{|c|c|c|c|c|c|c|c|c|}
\hline & \multicolumn{2}{|c|}{ All Youth (Ages 15-20) } & \multicolumn{2}{|c|}{ Female Youth } & \multicolumn{2}{|c|}{ Male Youth } & \multicolumn{2}{|c|}{ M - F Difference } \\
\hline & $\mathbf{E}-\mathbf{C}$ & $\mathbf{S}-\mathbf{C}$ & $\mathbf{E}-\mathbf{C}$ & $\mathbf{S}-\mathbf{C}$ & $\mathbf{E}-\mathbf{C}$ & $\mathbf{S}-\mathbf{C}$ & $\mathbf{E}-\mathbf{C}$ & $\mathbf{S}-\mathbf{C}$ \\
\hline \multicolumn{9}{|l|}{ A. Gender } \\
\hline \multirow[t]{2}{*}{ Math } & -0.041 & 0.010 & -0.026 & 0.007 & -0.057 & 0.014 & -0.031 & 0.007 \\
\hline & $(0.047)$ & $(0.053)$ & $(0.065)$ & $(0.075)$ & $(0.061)$ & $(0.067)$ & $(0.084)$ & $(0.097)$ \\
\hline \multirow[t]{2}{*}{ Reading } & -0.002 & 0.024 & -0.019 & 0.080 & 0.016 & -0.033 & 0.035 & -0.113 \\
\hline & $(0.044)$ & $(0.050)$ & $(0.062)$ & $(0.069)$ & $(0.060)$ & $(0.066)$ & $(0.083)$ & $(0.092)$ \\
\hline \multirow[t]{4}{*}{ Math \& Reading } & -0.027 & 0.020 & -0.032 & 0.041 & -0.021 & -0.002 & 0.011 & -0.043 \\
\hline & $(0.047)$ & $(0.053)$ & $(0.064)$ & $(0.074)$ & $(0.060)$ & $(0.067)$ & $(0.083)$ & $(0.094)$ \\
\hline & \multicolumn{2}{|c|}{ All Youth (Ages 13-20) } & \multicolumn{2}{|c|}{ " Under Age 6 at Baseline } & \multicolumn{2}{|c|}{ "Age 6 and Over at Baseline } & \multicolumn{2}{|c|}{ Difference by Age } \\
\hline & $\mathbf{E}-\mathbf{C}$ & $\mathrm{S}-\mathrm{C}$ & $E-C$ & $\mathbf{S}-\mathbf{C}$ & $\mathrm{E}-\mathrm{C}$ & $\mathrm{S}-\mathrm{C}$ & $\mathbf{E}-\mathbf{C}$ & $\mathrm{S}-\mathrm{C}$ \\
\hline \multicolumn{9}{|l|}{ B. Baseline age } \\
\hline \multirow[t]{2}{*}{ Math } & -0.032 & 0.011 & -0.059 & -0.039 & 0.005 & 0.074 & 0.064 & 0.113 \\
\hline & $(0.043)$ & $(0.048)$ & $(0.056)$ & $(0.058)$ & $(0.060)$ & $(0.072)$ & $(0.077)$ & $(0.087)$ \\
\hline \multirow[t]{2}{*}{ Reading } & -0.002 & 0.040 & 0.025 & 0.082 & -0.039 & -0.015 & -0.064 & -0.097 \\
\hline & $(0.041)$ & $(0.044)$ & $(0.052)$ & $(0.054)$ & $(0.060)$ & $(0.069)$ & $(0.076)$ & $(0.084)$ \\
\hline \multirow[t]{2}{*}{ Math \& Reading } & -0.015 & 0.030 & -0.014 & 0.019 & -0.018 & 0.043 & -0.004 & 0.024 \\
\hline & $(0.043)$ & $(0.047)$ & $(0.055)$ & $(0.056)$ & $(0.061)$ & $(0.072)$ & $(0.077)$ & $(0.086)$ \\
\hline \multicolumn{9}{|c|}{$\begin{array}{l}\text { Notes : E-C denotes Experimental vs. Control; } \mathrm{S}-\mathrm{C} \text { denotes Section } 8 \text { vs. Control. Estimates are the intent-to-treat effect sizes from an ordinary least } \\
\text { squares regression of each outcome on treatment indicators and the baseline covariates listed in Appendix Tables } 1 \text { and } 1 \mathrm{~B} \text {. The estimated equations all } \\
\text { include treatment indicators and the baseline covariates listed in Appendix Tables } 1 \text { and 1B. Impacts by gender and by age at baseline were estimated as } \\
\text { an interaction with treatment status. M - F difference is male - female difference. Difference by age is age } 6 \text { and over - under age } 6 \text {. Robust standard } \\
\text { errors adjusted for household clustering are in parentheses. Assessment scores are from Early Childhood Longitudinal Study-Kindergarten (ECLS-K) } \\
\text { cohort study assessments adapted for the MTO study. All measures were standardized using the mean and standard deviation for control group youth } \\
\text { (with male and female youth and youth under age } 6 \text { and age } 6 \text { and over standardized separately). The combined math and reading z-score is an average } \\
\text { of the math and reading score measures, restandardized as described above. } \\
\text { Source and Sample: The sample in both panels is youth who were interviewed as part of the long-term survey. Panel A includes youth ages } 15-20 \text { as of } \\
\text { December } 2007 \text {, and Panel B includes youth ages } 13-20 \text { as of the same date. }\end{array}$} \\
\hline
\end{tabular}




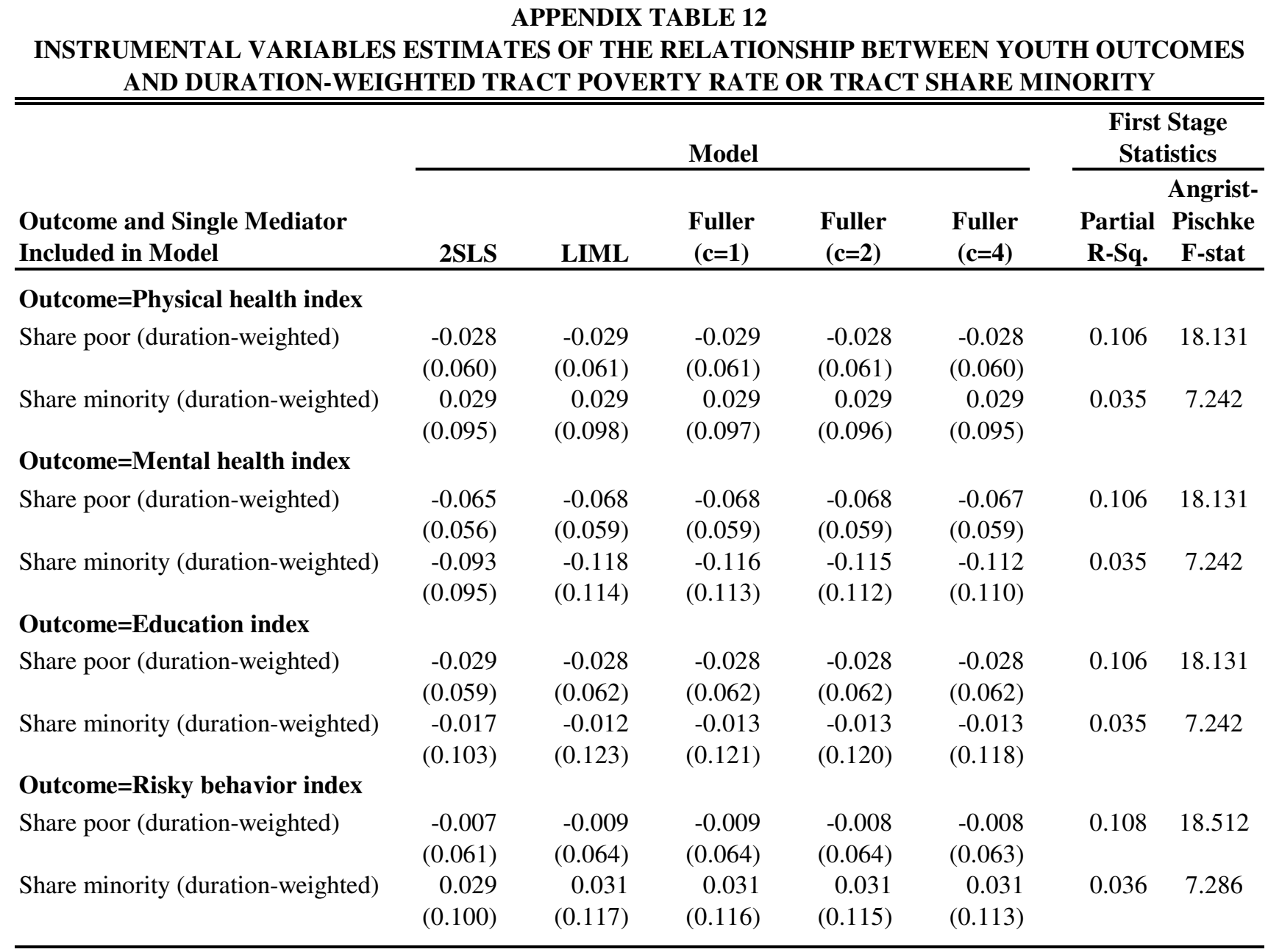

Notes : Coefficient estimates for the various instrumental variable regressions shown use site and treatment group interactions as instruments. Each regression also controlled for the baseline covariates presented in Appendix Tables 1 and $1 \mathrm{~B}$ and for field release and was weighted. Columns labels are as follows: 2SLS columns report results for two-stage least squares, LIML is an unmodified limited information maximum likelihood (LIML) model, and columns labeled Fuller present Fuller-modified LIML models with constants 1, 2 and 4, respectively. Robust standard errors adjusted for household clustering are in parentheses. All measures were converted to z-scores using the mean and standard deviation for control group youth ages 15-20 (with male and female youth standardized separately). See the notes to Table 2 for a description of the indices. Share poor is the fraction of census tract residents living below the poverty threshold, and share minority is the fraction of census tract residents who are members of racial or ethnic minority groups. Both share poor and share minority are average measures weighted by the amount of time respondents lived at each of their addresses between random assignment and May 31, 2008 (just prior to the start of the long-term survey fielding period). Source and Sample: Share poor and share minority come from interpolated data from the 1990 and 2000 decennial census as well as the 2005-09 American Community Survey, and the index measures are from the long-term survey. The sample is all youth ages 15-20 as of December 2007 who were interviewed as part of the long-term survey $(\mathrm{N}=3,621)$. 


\begin{tabular}{|c|c|c|c|c|c|c|c|c|}
\hline \multirow{3}{*}{$\begin{array}{l}\text { INSTRUMENTAL VARIABLE } \\
\text { DURATION-WEIGHTED T } \\
\\
\text { Outcome and Both Mediators } \\
\text { Included in Model }\end{array}$} & $\begin{array}{l}\text { ES ES } \\
\text { IRAC }\end{array}$ & $\begin{array}{r}\text { APPI } \\
\text { ES OF } \\
\text { ERTY }\end{array}$ & $\begin{array}{l}\text { DIX TAB } \\
\text { E RELA } \\
\text { TE OR T } \\
\end{array}$ & $\begin{array}{l}13 \\
\mathrm{NSH} \\
\mathrm{CT} \mathrm{SH}\end{array}$ & $\begin{array}{l}\text { WEE } \\
\text { MINO }\end{array}$ & \multicolumn{2}{|c|}{ SDD } & $\begin{array}{l}\text { IS AND } \\
\text { DEL }\end{array}$ \\
\hline & \multicolumn{5}{|c|}{ Model } & \multicolumn{3}{|c|}{ First Stage Statistics } \\
\hline & 2SLS & LIML & $\begin{array}{c}\text { Fuller } \\
(\mathbf{c}=1)\end{array}$ & $\begin{array}{c}\text { Fuller } \\
(\mathrm{c}=2)\end{array}$ & $\begin{array}{c}\text { Fuller } \\
(\mathbf{c}=4)\end{array}$ & $\begin{array}{c}\text { Partial } \\
\text { R-Sq. }\end{array}$ & $\begin{array}{c}\text { Angrist- } \\
\text { Pischke } \\
\text { F-stat } \\
\end{array}$ & $\begin{array}{c}\text { Cragg- } \\
\text { Donald } \\
\text { F-stat } \\
\end{array}$ \\
\hline \multicolumn{9}{|l|}{ Outcome $=$ Physical health index } \\
\hline $\begin{array}{l}\text { Share poor, controlling for share } \\
\text { minority (duration-weighted) }\end{array}$ & $\begin{array}{r}-0.078 \\
(0.086)\end{array}$ & $\begin{array}{r}-0.079 \\
(0.088)\end{array}$ & $\begin{array}{r}-0.079 \\
(0.087)\end{array}$ & $\begin{array}{r}-0.078 \\
(0.087)\end{array}$ & $\begin{array}{r}-0.078 \\
(0.085)\end{array}$ & 0.070 & 11.475 & 8.332 \\
\hline $\begin{array}{l}\text { Share minority, controlling for } \\
\text { share poor (duration-weighted) }\end{array}$ & $\begin{array}{r}0.124 \\
(0.138)\end{array}$ & $\begin{array}{r}0.127 \\
(0.142)\end{array}$ & $\begin{array}{r}0.126 \\
(0.141)\end{array}$ & $\begin{array}{r}0.125 \\
(0.139)\end{array}$ & $\begin{array}{r}0.123 \\
(0.136)\end{array}$ & 0.023 & 4.871 & \\
\hline $\begin{array}{l}\text { P-value of test that coefficients } \\
\text { are equal }\end{array}$ & 0.332 & 0.337 & 0.335 & 0.333 & 0.330 & & & \\
\hline \multicolumn{9}{|l|}{ Outcome=Mental health index } \\
\hline $\begin{array}{l}\text { Share poor, controlling for share } \\
\text { minority (duration-weighted) }\end{array}$ & $\begin{array}{r}-0.054 \\
(0.085)\end{array}$ & $\begin{array}{r}-0.047 \\
(0.102)\end{array}$ & $\begin{array}{r}-0.048 \\
(0.101)\end{array}$ & $\begin{array}{r}-0.048 \\
(0.100)\end{array}$ & $\begin{array}{r}-0.049 \\
(0.098)\end{array}$ & 0.070 & 11.475 & 8.332 \\
\hline $\begin{array}{l}\text { Share minority, controlling for } \\
\text { share poor (duration-weighted) }\end{array}$ & $\begin{array}{r}-0.026 \\
(0.143)\end{array}$ & $\begin{array}{r}-0.052 \\
(0.192)\end{array}$ & $\begin{array}{r}-0.051 \\
(0.189)\end{array}$ & $\begin{array}{r}-0.049 \\
(0.186)\end{array}$ & $\begin{array}{r}-0.046 \\
(0.180)\end{array}$ & 0.023 & 4.871 & \\
\hline $\begin{array}{l}\text { P-value of test that coefficients } \\
\text { are equal }\end{array}$ & 0.896 & 0.985 & 0.991 & 0.997 & 0.991 & & & \\
\hline \multicolumn{9}{|l|}{ Outcome=Education index } \\
\hline $\begin{array}{l}\text { Share poor, controlling for share } \\
\text { minority (duration-weighted) }\end{array}$ & $\begin{array}{r}-0.043 \\
(0.087)\end{array}$ & $\begin{array}{r}-0.051 \\
(0.104)\end{array}$ & $\begin{array}{r}-0.050 \\
(0.103)\end{array}$ & $\begin{array}{r}-0.050 \\
(0.102)\end{array}$ & $\begin{array}{r}-0.049 \\
(0.100)\end{array}$ & 0.070 & 11.475 & 8.332 \\
\hline $\begin{array}{l}\text { Share minority, controlling for } \\
\text { share poor (duration-weighted) }\end{array}$ & $\begin{array}{r}0.036 \\
(0.152)\end{array}$ & $\begin{array}{r}0.057 \\
(0.201)\end{array}$ & $\begin{array}{r}0.056 \\
(0.198)\end{array}$ & $\begin{array}{r}0.054 \\
(0.195)\end{array}$ & $\begin{array}{r}0.052 \\
(0.189)\end{array}$ & 0.023 & 4.871 & \\
\hline $\begin{array}{l}\text { P-value of test that coefficients } \\
\text { are equal }\end{array}$ & 0.726 & 0.711 & 0.712 & 0.713 & 0.714 & & & \\
\hline \multicolumn{9}{|l|}{ Outcome=Risky behavior index } \\
\hline $\begin{array}{l}\text { Share poor, controlling for share } \\
\text { minority (duration-weighted) }\end{array}$ & $\begin{array}{r}-0.037 \\
(0.085)\end{array}$ & $\begin{array}{r}-0.046 \\
(0.098)\end{array}$ & $\begin{array}{r}-0.046 \\
(0.097)\end{array}$ & $\begin{array}{r}-0.045 \\
(0.096)\end{array}$ & $\begin{array}{r}-0.044 \\
(0.095)\end{array}$ & 0.070 & 11.510 & 8.356 \\
\hline $\begin{array}{l}\text { Share minority, controlling for } \\
\text { share poor (duration-weighted) }\end{array}$ & $\begin{array}{r}0.075 \\
(0.139)\end{array}$ & $\begin{array}{r}0.094 \\
(0.180)\end{array}$ & $\begin{array}{r}0.093 \\
(0.177)\end{array}$ & $\begin{array}{r}0.092 \\
(0.174)\end{array}$ & $\begin{array}{r}0.089 \\
(0.169)\end{array}$ & 0.023 & 4.925 & \\
\hline $\begin{array}{l}\text { P-value of test that coefficients } \\
\text { are equal }\end{array}$ & 0.590 & 0.592 & 0.591 & 0.591 & 0.591 & & & \\
\hline
\end{tabular}

Notes: Coefficient estimates for the various instrumental variable regressions shown use site and treatment group interactions as instruments. Each regression presents coefficients for the respective neighborhood measure controlling for the other mediator listed. Each regression also controlled for the baseline covariates presented in Appendix Tables 1 and 1B and for field release and was weighted. Columns labels are as follows: 2SLS columns report results for two-stage least squares, LIML is an unmodified limited information maximum likelihood (LIML) model, and columns labeled Fuller present Fuller-modified LIML models with constants 1, 2 and 4, respectively. Robust standard errors adjusted for household clustering are in parentheses. All measures were converted to z-scores using mean and standard deviation for control group youth ages 15-20 (with male and female youth standardized separately). See the notes to Table 2 for a description of the indices. Share poor is the fraction of census tract residents living below the poverty threshold, and share minority is the fraction of census tract residents who are members of racial or ethnic minority groups. Both share poor and share minority are average measures weighted by the amount of time respondents lived at each of their addresses between random assignment and May 31, 2008 (just prior to the start of the long-term survey fielding period).

Source and Sample: Share poor and share minority come from interpolated data from the 1990 and 2000 decennial census as well as the 2005-09 American Community Survey, and the index measures are from the long-term survey. The sample is all youth ages 15-20 as of December 2007 who were interviewed as part of the long-term survey $(\mathrm{N}=3,621)$. 


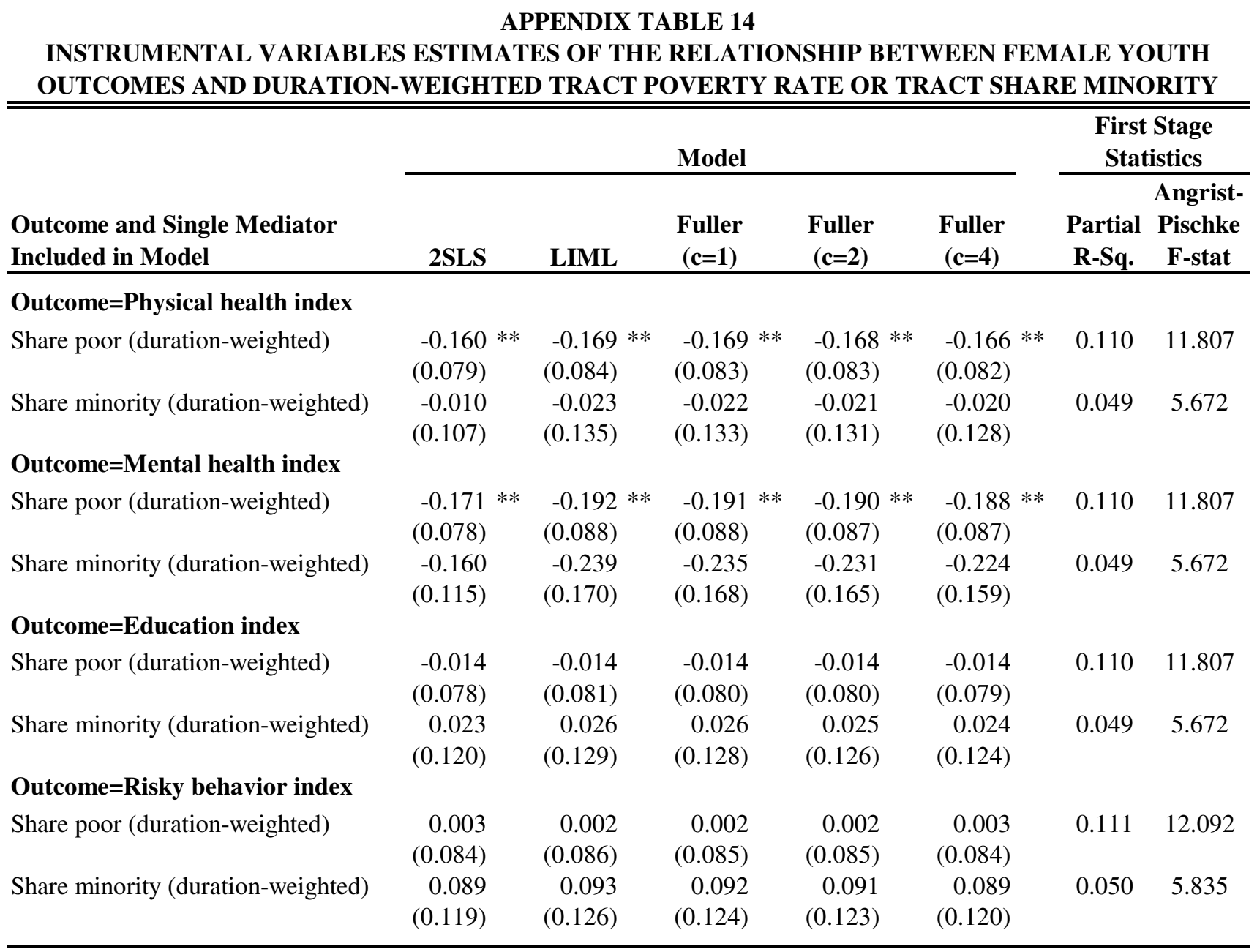

Notes : Coefficient estimates for the various instrumental variable regressions shown use site and treatment group interactions as instruments. Each regression also controlled for the baseline covariates presented in Appendix Tables 1 and $1 \mathrm{~B}$ and for field release and was weighted. Columns labels are as follows: 2SLS columns report results for two-stage least squares, LIML is an unmodified limited information maximum likelihood (LIML) model, and columns labeled Fuller present Fuller-modified LIML models with constants 1, 2 and 4, respectively. Robust standard errors adjusted for household clustering are in parentheses. All measures were converted to z-scores using the mean and standard deviation for control group youth ages 15-20 (with male and female youth standardized separately). See the notes to Table 2 for a description of the indices. Share poor is the fraction of census tract residents living below the poverty threshold, and share minority is the fraction of census tract residents who are members of racial or ethnic minority groups. Both share poor and share minority are average measures weighted by the amount of time respondents lived at each of their addresses between random assignment and May 31, 2008 (just prior to the start of the long-term survey fielding period). Source and Sample: Share poor and share minority come from interpolated data from the 1990 and 2000 decennial census as well as the 2005-09 American Community Survey, and the index measures are from the long-term survey. The sample is female youth ages 15-20 as of December 2007 who were interviewed as part of the long-term survey $(\mathrm{N}=1,845)$. 


\begin{tabular}{|c|c|c|c|c|c|c|c|c|}
\hline \multirow{3}{*}{$\begin{array}{l}\text { INSTRUMENTAL VARIA } \\
\text { OUTCOMES AND DURATIO } \\
\\
\text { Outcome and Both Mediators } \\
\text { Included in Model }\end{array}$} & $\begin{array}{l}\text { ABLES E: } \\
\text { ON-WEIC }\end{array}$ & $\begin{array}{r}\text { APPEN } \\
\text { IMATES O } \\
\text { TED TRAC }\end{array}$ & $\begin{array}{l}\text { THE REL } \\
\text { T POVERT }\end{array}$ & $\begin{array}{l}15 \\
\text { ATIONSHI } \\
\text { Y RATE AI }\end{array}$ & $\begin{array}{l}\text { BETWEE } \\
\text { ID TRACT }\end{array}$ & \multicolumn{3}{|c|}{$\begin{array}{l}\text { N FEMALE YOUTH } \\
\text { SHARE MINORITY IN }\end{array}$} \\
\hline & \multicolumn{5}{|c|}{ Model } & \multicolumn{3}{|c|}{ First Stage Statistics } \\
\hline & 2SLS & LIML & $\begin{array}{c}\text { Fuller } \\
(c=1)\end{array}$ & $\begin{array}{c}\text { Fuller } \\
(c=2)\end{array}$ & $\begin{array}{c}\text { Fuller } \\
(c=4)\end{array}$ & $\begin{array}{l}\text { Partial } \\
\text { R-Sq. }\end{array}$ & $\begin{array}{c}\text { Angrist- } \\
\text { Pischke } \\
\text { F-stat } \\
\end{array}$ & $\begin{array}{c}\text { Cragg- } \\
\text { Donald } \\
\text { F-stat } \\
\end{array}$ \\
\hline \multicolumn{9}{|l|}{ Outcome=Physical health index } \\
\hline $\begin{array}{l}\text { Share poor, controlling for share } \\
\text { minority (duration-weighted) }\end{array}$ & $\begin{array}{l}-0.252 * * \\
(0.107)\end{array}$ & $\begin{array}{l}-0.269 * * \\
(0.116)\end{array}$ & $\begin{array}{l}-0.267 * * \\
(0.115)\end{array}$ & $\begin{array}{l}-0.265 * * \\
(0.114)\end{array}$ & $\begin{array}{l}-0.261 * * \\
(0.112)\end{array}$ & 0.087 & 8.404 & 7.106 \\
\hline $\begin{array}{l}\text { Share minority, controlling for } \\
\text { share poor (duration-weighted) }\end{array}$ & $\begin{array}{r}0.225 \\
(0.148)\end{array}$ & $\begin{array}{r}0.249 \\
(0.172)\end{array}$ & $\begin{array}{r}0.246 \\
(0.169)\end{array}$ & $\begin{array}{r}0.244 \\
(0.166)\end{array}$ & $\begin{array}{r}0.238 \\
(0.161)\end{array}$ & 0.039 & 4.226 & \\
\hline $\begin{array}{l}\text { P-value of test that coefficients } \\
\text { are equal }\end{array}$ & 0.043 & 0.053 & 0.051 & 0.050 & 0.048 & & & \\
\hline \multicolumn{9}{|l|}{ Outcome=Mental health index } \\
\hline $\begin{array}{l}\text { Share poor, controlling for share } \\
\text { minority (duration-weighted) }\end{array}$ & $\begin{array}{l}-0.170 * \\
(0.102)\end{array}$ & $\begin{array}{r}-0.182 \\
(0.131)\end{array}$ & $\begin{array}{r}-0.182 \\
(0.129)\end{array}$ & $\begin{array}{r}-0.181 \\
(0.128)\end{array}$ & $\begin{array}{r}-0.180 \\
(0.125)\end{array}$ & 0.087 & 8.404 & 7.106 \\
\hline $\begin{array}{l}\text { Share minority, controlling for } \\
\text { share poor (duration-weighted) }\end{array}$ & $\begin{array}{r}-0.002 \\
(0.148)\end{array}$ & $\begin{array}{l}-0.025 \\
(0.228)\end{array}$ & $\begin{array}{l}-0.024 \\
(0.223)\end{array}$ & $\begin{array}{l}-0.022 \\
(0.218)\end{array}$ & $\begin{array}{r}-0.020 \\
(0.209)\end{array}$ & 0.039 & 4.226 & \\
\hline $\begin{array}{l}\text { P-value of test that coefficients } \\
\text { are equal }\end{array}$ & 0.462 & 0.641 & 0.632 & 0.623 & 0.606 & & & \\
\hline \multicolumn{9}{|l|}{ Outcome=Education index } \\
\hline $\begin{array}{l}\text { Share poor, controlling for share } \\
\text { minority (duration-weighted) }\end{array}$ & $\begin{array}{l}-0.038 \\
(0.106)\end{array}$ & $\begin{array}{r}-0.041 \\
(0.112)\end{array}$ & $\begin{array}{r}-0.040 \\
(0.111)\end{array}$ & $\begin{array}{r}-0.040 \\
(0.110)\end{array}$ & $\begin{array}{r}-0.039 \\
(0.108)\end{array}$ & 0.087 & 8.404 & 7.106 \\
\hline $\begin{array}{l}\text { Share minority, controlling for } \\
\text { share poor (duration-weighted) }\end{array}$ & $\begin{array}{r}0.058 \\
(0.162)\end{array}$ & $\begin{array}{r}0.066 \\
(0.179)\end{array}$ & $\begin{array}{r}0.064 \\
(0.176)\end{array}$ & $\begin{array}{r}0.063 \\
(0.174)\end{array}$ & $\begin{array}{r}0.061 \\
(0.168)\end{array}$ & 0.039 & 4.226 & \\
\hline $\begin{array}{l}\text { P-value of test that coefficients } \\
\text { are equal }\end{array}$ & 0.698 & 0.693 & 0.694 & 0.695 & 0.696 & & & \\
\hline \multicolumn{9}{|c|}{ Outcome=Risky behavior index } \\
\hline $\begin{array}{l}\text { Share poor, controlling for share } \\
\text { minority (duration-weighted) }\end{array}$ & $\begin{array}{l}-0.055 \\
(0.108)\end{array}$ & $\begin{array}{r}-0.060 \\
(0.111)\end{array}$ & $\begin{array}{r}-0.059 \\
(0.111)\end{array}$ & $\begin{array}{l}-0.058 \\
(0.110)\end{array}$ & $\begin{array}{l}-0.056 \\
(0.108)\end{array}$ & 0.088 & 8.434 & 7.356 \\
\hline $\begin{array}{l}\text { Share minority, controlling for } \\
\text { share poor (duration-weighted) }\end{array}$ & $\begin{array}{r}0.140 \\
(0.153)\end{array}$ & $\begin{array}{r}0.149 \\
(0.163)\end{array}$ & $\begin{array}{r}0.147 \\
(0.161)\end{array}$ & $\begin{array}{r}0.145 \\
(0.159)\end{array}$ & $\begin{array}{r}0.141 \\
(0.154)\end{array}$ & 0.040 & 4.392 & \\
\hline $\begin{array}{l}\mathrm{P} \text {-value of test that coefficients } \\
\text { are equal }\end{array}$ & 0.408 & 0.401 & 0.403 & 0.404 & 0.407 & & & \\
\hline
\end{tabular}

Notes: Coefficient estimates for the various instrumental variable regressions shown use site and treatment group interactions as instruments. Each regression presents coefficients for the respective neighborhood measure controlling for the other mediator listed. Each regression also controlled for the baseline covariates presented in Appendix Tables 1 and 1B and for field release and was weighted. Columns labels are as follows: 2SLS columns report results for two-stage least squares, LIML is an unmodified limited information maximum likelihood (LIML) model, and columns labeled Fuller present Fullermodified LIML models with constants 1, 2 and 4, respectively. Robust standard errors adjusted for household clustering are in parentheses. All measures were converted to z-scores using mean and standard deviation for control group youth ages 1520 (with male and female youth standardized separately). See the notes to Table 2 for a description of the indices. Share poor is the fraction of census tract residents living below the poverty threshold, and share minority is the fraction of census tract residents who are members of racial or ethnic minority groups. Both share poor and share minority are average measures weighted by the amount of time respondents lived at each of their addresses between random assignment and May 31, 2008 (just prior to the start of the long-term survey fielding period).

Source and Sample: Share poor and share minority come from interpolated data from the 1990 and 2000 decennial census as well as the 2005-09 American Community Survey, and the index measures are from the long-term survey. The sample is female youth ages 15-20 as of December 2007 who were interviewed as part of the long-term survey $(\mathrm{N}=1,845)$. 


\section{APPENDIX TABLE 16 \\ INSTRUMENTAL VARIABLES ESTIMATES OF THE RELATIONSHIP BETWEEN MALE YOUTH OUTCOMES AND DURATION-WEIGHTED TRACT POVERTY RATE OR TRACT SHARE MINORITY}

\begin{tabular}{|c|c|c|c|c|c|c|c|}
\hline \multirow[b]{2}{*}{$\begin{array}{l}\text { Outcome and Single Mediator } \\
\text { Included in Model }\end{array}$} & \multicolumn{5}{|c|}{ Model } & \multicolumn{2}{|c|}{$\begin{array}{c}\text { First Stage } \\
\text { Statistics }\end{array}$} \\
\hline & 2SLS & LIML & $\begin{array}{c}\text { Fuller } \\
(c=1)\end{array}$ & $\begin{array}{c}\text { Fuller } \\
(c=2)\end{array}$ & $\begin{array}{c}\text { Fuller } \\
(c=4)\end{array}$ & $\begin{array}{l}\text { Partial } \\
\text { R-Sq. }\end{array}$ & $\begin{array}{c}\text { Angrist- } \\
\text { Pischke } \\
\text { F-stat }\end{array}$ \\
\hline \multicolumn{8}{|l|}{ Outcome=Physical health index } \\
\hline Share poor (duration-weighted) & $\begin{array}{r}0.112 \\
(0.088)\end{array}$ & $\begin{array}{r}0.114 \\
(0.089)\end{array}$ & $\begin{array}{r}0.114 \\
(0.089)\end{array}$ & $\begin{array}{r}0.113 \\
(0.089)\end{array}$ & $\begin{array}{r}0.112 \\
(0.088)\end{array}$ & 0.108 & 11.709 \\
\hline Share minority (duration-weighted) & $\begin{array}{r}0.084 \\
(0.156)\end{array}$ & $\begin{array}{r}0.091 \\
(0.175)\end{array}$ & $\begin{array}{r}0.090 \\
(0.171)\end{array}$ & $\begin{array}{r}0.088 \\
(0.168)\end{array}$ & $\begin{array}{r}0.086 \\
(0.162)\end{array}$ & 0.031 & 4.354 \\
\hline \multicolumn{8}{|l|}{ Outcome=Mental health index } \\
\hline Share poor (duration-weighted) & $\begin{array}{r}0.044 \\
(0.080)\end{array}$ & $\begin{array}{r}0.046 \\
(0.084)\end{array}$ & $\begin{array}{r}0.045 \\
(0.083)\end{array}$ & $\begin{array}{r}0.045 \\
(0.083)\end{array}$ & $\begin{array}{r}0.045 \\
(0.082)\end{array}$ & 0.108 & 11.709 \\
\hline Share minority (duration-weighted) & $\begin{array}{r}-0.003 \\
(0.143)\end{array}$ & $\begin{array}{r}-0.015 \\
(0.173)\end{array}$ & $\begin{array}{r}-0.013 \\
(0.169)\end{array}$ & $\begin{array}{l}-0.012 \\
(0.165)\end{array}$ & $\begin{array}{r}-0.009 \\
(0.159)\end{array}$ & 0.031 & 4.354 \\
\hline \multicolumn{8}{|l|}{ Outcome=Education index } \\
\hline Share poor (duration-weighted) & $\begin{array}{r}-0.044 \\
(0.080)\end{array}$ & $\begin{array}{r}-0.041 \\
(0.091)\end{array}$ & $\begin{array}{r}-0.041 \\
(0.090)\end{array}$ & $\begin{array}{r}-0.041 \\
(0.090)\end{array}$ & $\begin{array}{r}-0.042 \\
(0.089)\end{array}$ & 0.108 & 11.709 \\
\hline Share minority (duration-weighted) & $\begin{array}{r}-0.144 \\
(0.150)\end{array}$ & $\begin{array}{l}-0.210 \\
(0.269)\end{array}$ & $\begin{array}{l}-0.205 \\
(0.260)\end{array}$ & $\begin{array}{l}-0.201 \\
(0.252)\end{array}$ & $\begin{array}{r}-0.193 \\
(0.238)\end{array}$ & 0.031 & 4.354 \\
\hline \multicolumn{8}{|l|}{ Outcome=Risky behavior index } \\
\hline Share poor (duration-weighted) & $\begin{array}{r}-0.038 \\
(0.079)\end{array}$ & $\begin{array}{r}-0.043 \\
(0.085)\end{array}$ & $\begin{array}{r}-0.043 \\
(0.085)\end{array}$ & $\begin{array}{r}-0.042 \\
(0.084)\end{array}$ & $\begin{array}{r}-0.042 \\
(0.084)\end{array}$ & 0.109 & 11.892 \\
\hline Share minority (duration-weighted) & $\begin{array}{r}-0.138 \\
(0.140)\end{array}$ & $\begin{array}{r}-0.199 \\
(0.196)\end{array}$ & $\begin{array}{l}-0.193 \\
(0.191)\end{array}$ & $\begin{array}{r}-0.188 \\
(0.186)\end{array}$ & $\begin{array}{r}-0.178 \\
(0.177)\end{array}$ & 0.032 & 4.354 \\
\hline
\end{tabular}

Notes : Coefficient estimates for the various instrumental variable regressions shown use site and treatment group interactions as instruments. Each regression also controlled for the baseline covariates presented in Appendix Tables 1 and 1B and for field release and was weighted. Columns labels are as follows: 2SLS columns report results for two-stage least squares, LIML is an unmodified limited information maximum likelihood (LIML) model, and columns labeled Fuller present Fuller-modified LIML models with constants 1, 2 and 4, respectively. Robust standard errors adjusted for household clustering are in parentheses. All measures were converted to z-scores using the mean and standard deviation for control group youth ages 15-20 (with male and female youth standardized separately). See the notes to Table 2 for a description of the indices. Share poor is the fraction of census tract residents living below the poverty threshold, and share minority is the fraction of census tract residents who are members of racial or ethnic minority groups. Both share poor and share minority are average measures weighted by the amount of time respondents lived at each of their addresses between random assignment and May 31, 2008 (just prior to the start of the long-term survey fielding period). Source and Sample: Share poor and share minority come from interpolated data from the 1990 and 2000 decennial census as well as the 2005-09 American Community Survey, and the index measures are from the long-term survey. The sample is male youth ages 15-20 as of December 2007 who were interviewed as part of the long-term survey $(\mathrm{N}=1,776)$. 


\begin{tabular}{|c|c|c|c|c|c|c|c|c|}
\hline \multirow{3}{*}{$\begin{array}{l}\text { INSTRUMENTAL VARI } \\
\text { OUTCOMES AND DURATIO } \\
\\
\text { Outcome and Both Mediators } \\
\text { Included in Model }\end{array}$} & $\begin{array}{l}\text { IABLF } \\
\text { ON-W }\end{array}$ & $\begin{array}{r}\text { APPI } \\
\text { IMATE } \\
\text { CDD TR }\end{array}$ & $\begin{array}{l}\text { OIX TAB } \\
\text { OF THE } \\
\text { T POVE }\end{array}$ & $\begin{array}{l}17 \\
\text { LATIO } \\
\text { Y RAT }\end{array}$ & $\begin{array}{l}\mathbf{P} \text { BE } \\
\text { D TR }\end{array}$ & $\begin{array}{l}\text { EN M } \\
\text { SHAF }\end{array}$ & $\begin{array}{l}\text { E YO } \\
\text { MINO }\end{array}$ & $\begin{array}{l}\text { TH } \\
\text { ITY IN }\end{array}$ \\
\hline & & & Model & & & First & $\overline{\text { Stage Sta }}$ & atistics \\
\hline & 2SLS & LIML & $\begin{array}{c}\text { Fuller } \\
(c=1)\end{array}$ & $\begin{array}{c}\text { Fuller } \\
(c=2)\end{array}$ & $\begin{array}{c}\text { Fuller } \\
(c=4)\end{array}$ & $\begin{array}{l}\text { Partial } \\
\text { R-Sq. }\end{array}$ & $\begin{array}{c}\text { Angrist- } \\
\text { Pischke } \\
\text { F-stat } \\
\end{array}$ & $\begin{array}{c}\text { Cragg- } \\
\text { Donald } \\
\text { F-stat } \\
\end{array}$ \\
\hline Outcome $=$ Physical health index & & & & & & & & \\
\hline $\begin{array}{l}\text { Share poor, controlling for share } \\
\text { minority (duration-weighted) }\end{array}$ & $\begin{array}{r}0.167 \\
(0.127)\end{array}$ & $\begin{array}{r}0.175 \\
(0.135)\end{array}$ & $\begin{array}{r}0.173 \\
(0.133)\end{array}$ & $\begin{array}{r}0.170 \\
(0.131)\end{array}$ & $\begin{array}{r}0.166 \\
(0.126)\end{array}$ & 0.067 & 7.367 & 3.310 \\
\hline $\begin{array}{l}\text { Share minority, controlling for } \\
\text { share poor (duration-weighted) }\end{array}$ & $\begin{array}{l}-0.140 \\
(0.222)\end{array}$ & $\begin{array}{r}-0.159 \\
(0.249)\end{array}$ & $\begin{array}{r}-0.153 \\
(0.240)\end{array}$ & $\begin{array}{r}-0.148 \\
(0.233)\end{array}$ & $\begin{array}{r}-0.138 \\
(0.219)\end{array}$ & 0.019 & 2.672 & \\
\hline $\begin{array}{l}\text { P-value of test that coefficients } \\
\text { are equal }\end{array}$ & 0.346 & 0.354 & 0.352 & 0.349 & 0.345 & & & \\
\hline Outcome $=$ Mental health index & & & & & & & & \\
\hline $\begin{array}{l}\text { Share poor, controlling for share } \\
\text { minority (duration-weighted) }\end{array}$ & $\begin{array}{r}0.094 \\
(0.125)\end{array}$ & $\begin{array}{r}0.120 \\
(0.151)\end{array}$ & $\begin{array}{r}0.116 \\
(0.147)\end{array}$ & $\begin{array}{r}0.113 \\
(0.143)\end{array}$ & $\begin{array}{r}0.106 \\
(0.136)\end{array}$ & 0.067 & 7.367 & 3.310 \\
\hline $\begin{array}{l}\text { Share minority, controlling for } \\
\text { share poor (duration-weighted) }\end{array}$ & $\begin{array}{r}-0.130 \\
(0.223)\end{array}$ & $\begin{array}{l}-0.194 \\
(0.301)\end{array}$ & $\begin{array}{l}-0.185 \\
(0.288)\end{array}$ & $\begin{array}{l}-0.175 \\
(0.277)\end{array}$ & $\begin{array}{r}-0.159 \\
(0.258)\end{array}$ & 0.019 & 2.672 & \\
\hline $\begin{array}{l}\text { P-value of test that coefficients } \\
\text { are equal }\end{array}$ & 0.495 & 0.467 & 0.470 & 0.473 & 0.480 & & & \\
\hline Outcome=Education index & & & & & & & & \\
\hline $\begin{array}{l}\text { Share poor, controlling for share } \\
\text { minority (duration-weighted) }\end{array}$ & $\begin{array}{r}0.025 \\
(0.115)\end{array}$ & $\begin{array}{r}0.147 \\
(0.305)\end{array}$ & $\begin{array}{r}0.131 \\
(0.277)\end{array}$ & $\begin{array}{r}0.118 \\
(0.253)\end{array}$ & $\begin{array}{r}0.097 \\
(0.219)\end{array}$ & 0.067 & 7.367 & 3.310 \\
\hline $\begin{array}{l}\text { Share minority, controlling for } \\
\text { share poor (duration-weighted) }\end{array}$ & $\begin{array}{r}-0.178 \\
(0.217)\end{array}$ & $\begin{array}{r}-0.500 \\
(0.785)\end{array}$ & $\begin{array}{l}-0.457 \\
(0.704)\end{array}$ & $\begin{array}{r}-0.422 \\
(0.638)\end{array}$ & $\begin{array}{r}-0.367 \\
(0.538)\end{array}$ & 0.019 & 2.672 & \\
\hline $\begin{array}{l}\text { P-value of test that coefficients } \\
\text { are equal }\end{array}$ & 0.514 & 0.549 & 0.543 & 0.538 & 0.531 & & & \\
\hline Outcome=Risky behavior index & & & & & & & & \\
\hline $\begin{array}{l}\text { Share poor, controlling for share } \\
\text { minority (duration-weighted) }\end{array}$ & $\begin{array}{r}0.034 \\
(0.116)\end{array}$ & $\begin{array}{r}0.094 \\
(0.174)\end{array}$ & $\begin{array}{r}0.087 \\
(0.167)\end{array}$ & $\begin{array}{r}0.081 \\
(0.160)\end{array}$ & $\begin{array}{r}0.069 \\
(0.149)\end{array}$ & 0.065 & 7.317 & 3.239 \\
\hline $\begin{array}{l}\text { Share minority, controlling for } \\
\text { share poor (duration-weighted) }\end{array}$ & $\begin{array}{l}-0.184 \\
(0.203)\end{array}$ & $\begin{array}{l}-0.355 \\
(0.382)\end{array}$ & $\begin{array}{r}-0.335 \\
(0.360)\end{array}$ & $\begin{array}{r}-0.317 \\
(0.340)\end{array}$ & $\begin{array}{l}-0.285 \\
(0.306)\end{array}$ & 0.019 & 2.647 & \\
\hline $\begin{array}{l}\text { P-value of test that coefficients } \\
\text { are equal }\end{array}$ & 0.464 & 0.404 & 0.406 & 0.409 & 0.416 & & & \\
\hline
\end{tabular}

Notes: Coefficient estimates for the various instrumental variable regressions shown use site and treatment group interactions as instruments. Each regression presents coefficients for the respective neighborhood measure controlling for the other mediator listed. Each regression also controlled for the baseline covariates presented in Appendix Tables 1 and 1B and for field release and was weighted. Columns labels are as follows: 2SLS columns report results for two-stage least squares, LIML is an unmodified limited information maximum likelihood (LIML) model, and columns labeled Fuller present Fullermodified LIML models with constants 1, 2 and 4, respectively. Robust standard errors adjusted for household clustering are in parentheses. All measures were converted to z-scores using mean and standard deviation for control group youth ages 1520 (with male and female youth standardized separately). See the notes to Table 2 for a description of the indices. Share poor is the fraction of census tract residents living below the poverty threshold, and share minority is the fraction of census tract residents who are members of racial or ethnic minority groups. Both share poor and share minority are average measures weighted by the amount of time respondents lived at each of their addresses between random assignment and May 31, 2008 (just prior to the start of the long-term survey fielding period).

Source and Sample: Share poor and share minority come from interpolated data from the 1990 and 2000 decennial census as well as the 2005-09 American Community Survey, and the index measures are from the long-term survey. The sample is male youth ages 15-20 as of December 2007 who were interviewed as part of the long-term survey $(\mathrm{N}=1,776)$. 


\section{Appendix Exhibit References}

Ludwig, Jens. 2012. "The Long-Term Results From the Moving to Opportunity Residential Mobility Demonstration." Cityscape 14 (2): $1-28$.

Sampson, Robert J., Patrick Sharkey, and Stephen W. Raudenbush. 2008. "Durable Effects of Concentrated Disadvantage on Verbal Ability Among African-American Children." Proceedings of the National Academy of Sciences 105 (3): 845-852. 